Prepared in cooperation with the Missouri River Recovery-Integrated Science Program U.S. Army Corps of Engineers, Yankton, South Dakota

\title{
Ecological Requirements for Pallid Sturgeon Reproduction and Recruitment in the Lower Missouri River: Annual Report 2009
}
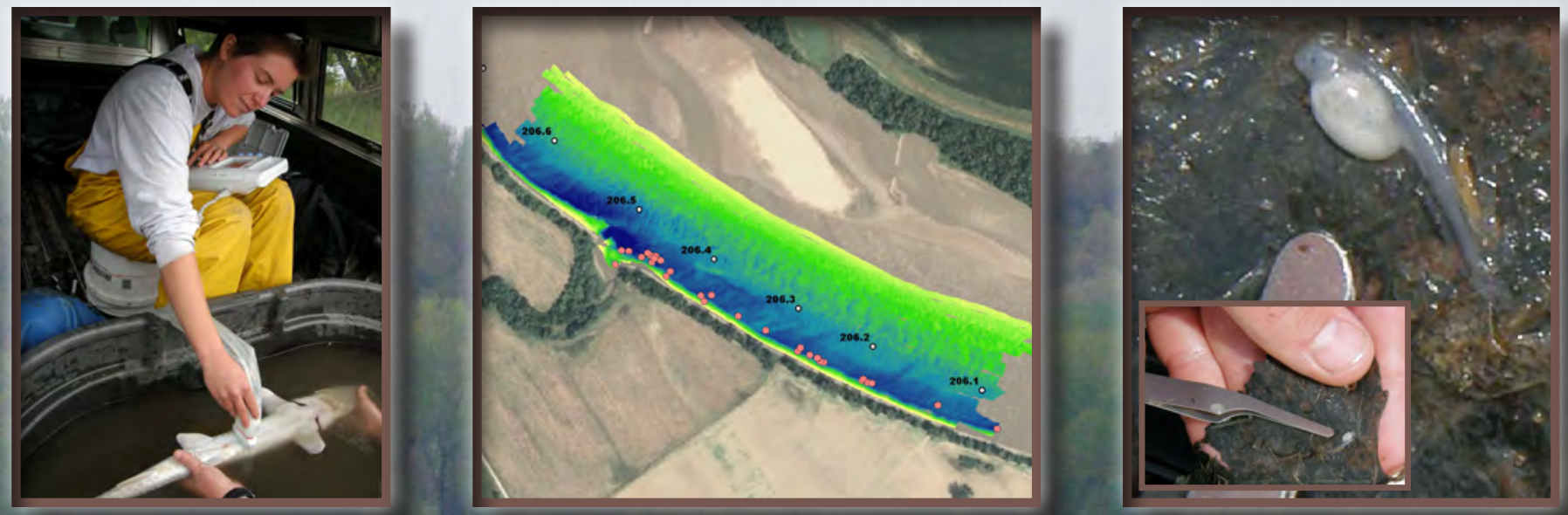

\section{Open-File Report 2010-1215}


Cover background. Research vessels tracking telemetry tagged pallid sturgeon in the Lower Missouri River during a high water event in 2009.

Cover left. Biologist Sabrina Davenport evaluates the reproductive condition of an adult pallid sturgeon using a portable ultrasound unit.

Cover middle. Multibeam bathymetric map of probable spawning habitat used by pallid sturgeon female PLS09-007 in the Lower Missouri River.

Cover right. Acipensiformes larvae collected in the Lower Missouri River downstream from an observed aggregation of tagged pallid sturgeon. 


\section{Ecological Requirements for Pallid Sturgeon Reproduction and Recruitment in the Lower Missouri River: Annual Report 2009}

By Aaron J. DeLonay, Robert B. Jacobson, Diana M. Papoulias, Mark. L. Wildhaber, Kimberly A. Chojnacki, Emily K. Pherigo, Casey L. Bergthold, and Gerald E. Mestl

Prepared in cooperation with the Missouri River Recovery-Integrated Science Program U.S. Army Corps of Engineers, Yankton, South Dakota

Open-File Report 2010-1215 


\section{U.S. Department of the Interior \\ KEN SALAZAR, Secretary \\ U.S. Geological Survey \\ Marcia K. McNutt, Director}

U.S. Geological Survey, Reston, Virginia: 2010

This and other USGS information products are available at http://store.usgs.gov/
U.S. Geological Survey
Box 25286 , Denver Federal Center
Denver, CO 80225
To learn about the USGS and its information products visit http://www.usgs.gov/
1-888-ASK-USGS

Any use of trade, product, or firm names is for descriptive purposes only and does not imply endorsement by the U.S. Government.

Although this report is in the public domain, permission must be secured from the individual copyright owners to reproduce any copyrighted materials contained within this report.

Suggested citation:

DeLonay, A.J., Jacobson, R.B., Papoulias, D.M., Wildhaber M.L., Chojnacki, K.A., Pherigo, E.K., Bergthold, C.L., and Mestl, G.E., 2010, Ecological requirements for pallid sturgeon reproduction and recruitment in the Lower Missouri River: Annual report 2009: U.S. Geological Survey Open-File Report 2010-1215, 64 p. 


\section{Contents}

Abstract

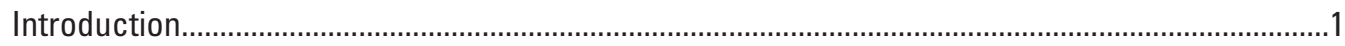

Scope of Work

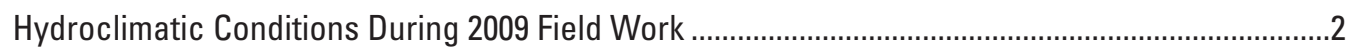

Accomplishments and Products ...........................................................................................

Future Research into Reproductive Ecology of Missouri River Pallid Sturgeon..............................10

Detailed Research Task Activities and Progress ..........................................................................10

Task 1. Movement, Habitat Use, and Reproductive Behavior of Shovelnose

Sturgeon and Pallid Sturgeon in the Lower Missouri River ..........................................10

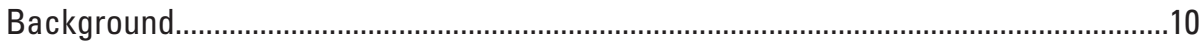

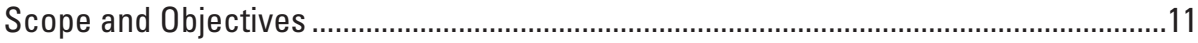

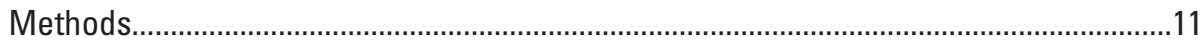

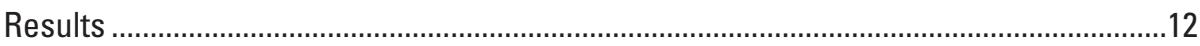

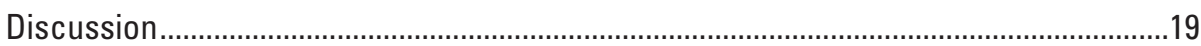

Summary and Conclusions.......................................................................................19

Task 2. Reproductive Physiology to Support Assessment of the Importance of Spring Flows, Temperature, and Photoperiod to Successful Pallid

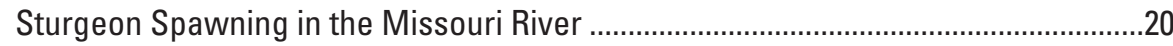

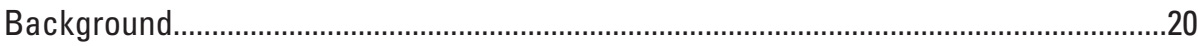

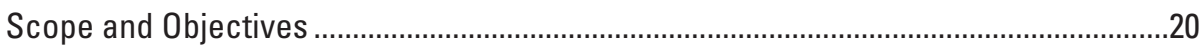

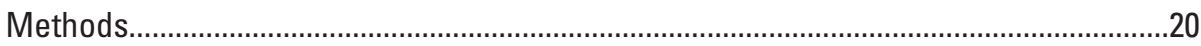

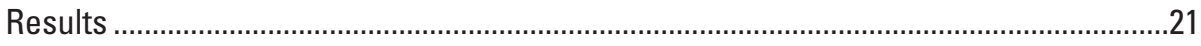

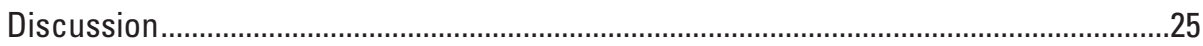

Summary and Conclusions.........................................................................................25

Task 3. Quantify Pallid Sturgeon Migration and Spawning Habitat.........................................25

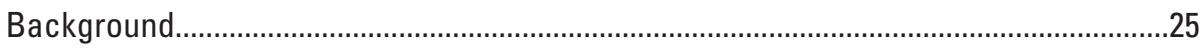

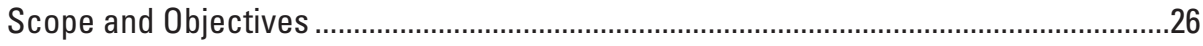

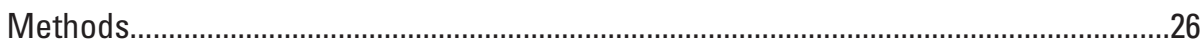

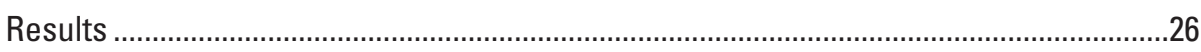

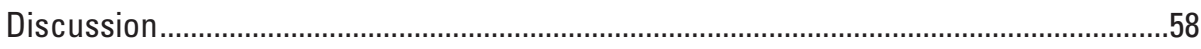

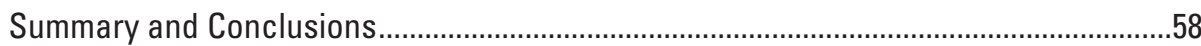

Task 4. Provide Database Integration, GIS Support, and

Report Coordination .................................................................................................

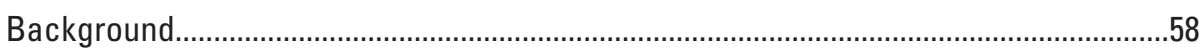

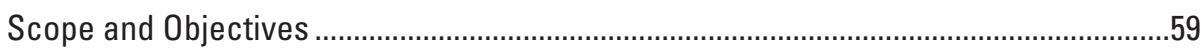

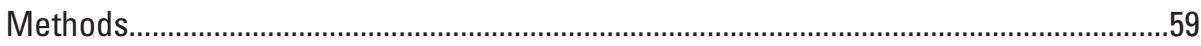

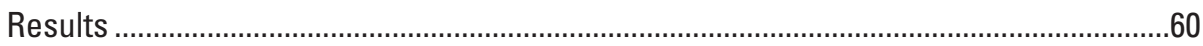

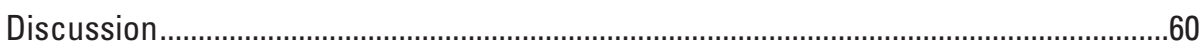

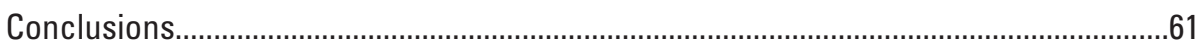

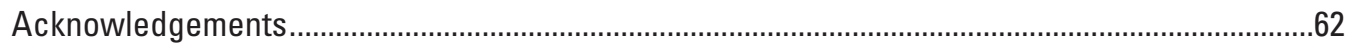

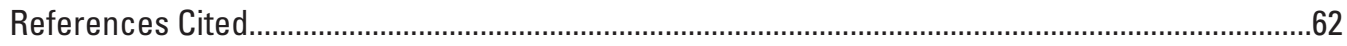




\section{Figures}

1. Map showing Missouri River Basin and major tributary rivers (upper map) with the Comprehensive Sturgeon Research Project study areas and 2009 probable spawning sites (lower map).

2. Graph showing 2009 Lower Missouri River hydrograph with water temperature.

3. Graph showing length-weight relation of hatchery-released, unknown, and wild pallid sturgeon collected during 2007, 2008, and 2009 spring

sampling efforts in both the upper and lower study sections.

4. Map and graph showing movement range of pallid sturgeon PLS09-007.

Depth and temperature recorded from data storage tags (DST), discharge

from the nearest gage, and telemetry locations for implanted gravid pallid sturgeon PLS09-007.

5. Map and graph showing movement range of pallid sturgeon PLS09-009.

Temperature and discharge from the nearest upstream gage and telemetry

locations for implanted gravid pallid sturgeon PLS09-009.

6-8 Graphs showing-

6. Telemetry locations of gravid female pallid sturgeon

PLS09-009 and reproductive male pallid sturgeon PLS09-003,

PLS07-020, and PLS08-036 showing probable spawning aggregations.

7. Telemetry locations for implanted pallid sturgeon

PLS08-002, PLS08-006, PLS08-012, PLS08-014, and PLS08-015

8. Female pallid sturgeon tracked in 2009 in the

Missouri River

9. Boxplot showing male pallid sturgeon tracked in 2009 in the Missouri River

10. Graph showing hormone levels on day of capture for reproductive pallid sturgeon captured in 2006-09 in two sections of the Missouri River, and discharge and temperature profiles in these river sections.....

11-40 Maps showing -

11. Multibeam bathymetry with location of migrating male pallid sturgeon PLS09-004, acoustic tag 1048.

12. Multibeam bathymetry with location of migrating male pallid sturgeon PLS09-002, acoustic tag 1047

13. Single-beam depth with location of migrating male pallid sturgeon PLS09-002, acoustic tag 1047

14. Acoustic Doppler current profiler velocity with location of migrating male pallid sturgeon PLS09-002, acoustic tag 1047

15. Multibeam bathymetry with location of migrating male pallid sturgeon PLS09-003, acoustic tag 1036, along with reproductive male PLS07-020, acoustic tag 558, and male PLS07-006, acoustic $\operatorname{tag} 802$ 
16. Single-beam depth with location of migrating male pallid sturgeon PLS09-003, acoustic tag 1036, along with reproductive male PLS07-020, acoustic tag 558, and male PLS07-006, acoustic $\operatorname{tag} 802$

17. Acoustic Doppler current profiler velocity with location of migrating male pallid sturgeon PLS09-003, acoustic tag 1036, along with reproductive male PLS07-020, acoustic tag 558, and male PLS07-006, acoustic tag 802

18. Single-beam depth with location of migrating male pallid sturgeon PLS09-008, acoustic tag 1046

19. Acoustic Doppler current profiler velocity with location of migrating male pallid sturgeon PLS09-008, acoustic tag 1046.

20. Multibeam bathymetry with location of migrating female pallid sturgeon PLS09-007, acoustic tag 54500

21. Single-beam depth with location of migrating female pallid sturgeon PLS09-007, acoustic tag 54500

22. Acoustic Doppler current profiler velocity with location of migrating female pallid sturgeon PLS09-007, acoustic tag 54500.

23. Multibeam bathymetry with location of migrating female pallid sturgeon PLS09-007, acoustic tag 54500

24. Single-beam depth with location of migrating female pallid sturgeon PLS09-007, acoustic tag 54500

25. Acoustic Doppler current profiler velocity with location of migrating female pallid sturgeon PLS09-007, acoustic tag 54500

26. Multibeam bathymetry with location of probable spawning site of female pallid sturgeon PLS09-007, acoustic tag 54500 .

27. Single-beam depth with location of probable spawning site of female pallid sturgeon PLS09-007, acoustic tag 54500

28. Acoustic Doppler current profiler velocity with location of probable spawning site of female pallid sturgeon PLS09-007, acoustic tag 54500

29. Multibeam bathymetry with location of probable spawning site of female pallid sturgeon PLS09-009, acoustic tag 54604, along with reproductive males PLS07-020, acoustic tag 558, PLS08-036, acoustic tag 1010, and PLS09-003, acoustic tag 1036

30. Single-beam depth with location of probable spawning site of female pallid sturgeon PLS09-009, acoustic tag 54604 along with reproductive males PLS07-020, acoustic tag 558, PLS08-036, acoustic tag 1010, and PLS09-003, acoustic tag 1036

31. Acoustic Doppler current profiler velocity with probable spawning site of female pallid sturgeon PLS09-009, acoustic tag 54604 along with reproductive males PLS07-020, acoustic tag 558, PLS08-036, acoustic tag 1010, and PLS09-003, acoustic tag 1036. 
32. Multibeam bathymetry with location of probable spawning site of female pallid sturgeon PLS09-009, acoustic tag 54604, along with reproductive males PLS07-020, acoustic tag 558, and PLS09-003, acoustic tag 1036.

33. Single-beam depth with location of probable spawning site of female pallid sturgeon PLS09-009, acoustic tag 54604, along with reproductive males PLS07-020, acoustic tag 558, and PLS09-003, acoustic tag 1036

34. Acoustic Doppler current profiler velocity with location of probable spawning site of female pallid sturgeon PLS09-009, acoustic tag 54604, along with reproductive males PLS07-020, acoustic tag 558, and PLS09-003, acoustic tag 1036

35. Multibeam bathymetry with location of migrating female pallid sturgeon PLS09-007, acoustic tag 54500

36. Single-beam depth with location of migrating female pallid sturgeon PLS09-007, acoustic tag 54500

37. Acoustic Doppler current profiler velocity with location of migrating female pallid sturgeon PLS09-007, acoustic tag 54500

38. Multibeam bathymetry with location of migrating female pallid sturgeon PLS09-007, acoustic tag 54500

39. Single-beam depth with location of migrating female pallid sturgeon PLS09-007, acoustic tag 54500

40. Acoustic Doppler current profiler velocity with location of migrating female pallid sturgeon PLS09-007, acoustic tag 54500

41. Diagram of the database platform illustrating data outflow and data inflow.

42. An example of the Individual Fish Summary report generated via the user interface

\section{Tables}

1. Missouri River Sturgeon Project Products, U.S. Geological Survey Columbia Environmental Research Center, 2009

2. Numbers of pallid sturgeon implanted with transmitters and recaptured in two Lower Missouri River study sections, 2005-09

3. Dates and information on detailed habitat assessments, 2009 


\section{Conversion Factors}

Inch/Pound to SI

\begin{tabular}{lcc}
\hline Multiply & By & To obtain \\
\hline mile $(\mathrm{mi})$ & Length & kilometer $(\mathrm{km})$ \\
\hline & 1.609 & \\
\hline cubic foot per second $\left(\mathrm{ft}^{3} / \mathrm{s}\right)$ & Flow rate & cubic meter per second $\left(\mathrm{m}^{3} / \mathrm{s}\right)$
\end{tabular}

SI to Inch/Pound

\begin{tabular}{|c|c|c|}
\hline Multiply & By & To obtain \\
\hline \multicolumn{3}{|c|}{ Length } \\
\hline micrometer $(\mu \mathrm{m})$ & 0.0000397 & inch (in.) \\
\hline millimeter (mm) & 0.03937 & inch (in.) \\
\hline centimeter $(\mathrm{cm})$ & 0.3937 & inch (in.) \\
\hline meter $(\mathrm{m})$ & 3.281 & foot $(\mathrm{ft})$ \\
\hline kilometer (km) & 0.6214 & mile (mi) \\
\hline meter $(\mathrm{m})$ & 1.094 & yard (yd) \\
\hline \multicolumn{3}{|c|}{ Area } \\
\hline square meter $\left(\mathrm{m}^{2}\right)$ & 10.76 & square foot $\left(\mathrm{ft}^{2}\right)$ \\
\hline hectare (ha) & 0.003861 & square mile $\left(\mathrm{mi}^{2}\right)$ \\
\hline square kilometer $\left(\mathrm{km}^{2}\right)$ & 0.3861 & square mile $\left(\mathrm{mi}^{2}\right)$ \\
\hline \multicolumn{3}{|c|}{ Volume } \\
\hline cubic meter $\left(\mathrm{m}^{3}\right)$ & 264.2 & gallon (gal) \\
\hline cubic meter $\left(\mathrm{m}^{3}\right)$ & 35.31 & cubic foot $\left(\mathrm{ft}^{3}\right)$ \\
\hline cubic meter $\left(\mathrm{m}^{3}\right)$ & 1.308 & cubic yard $\left(\mathrm{yd}^{3}\right)$ \\
\hline \multicolumn{3}{|c|}{ Flow rate } \\
\hline meter per second $(\mathrm{m} / \mathrm{s})$ & 3.281 & foot per second $(\mathrm{ft} / \mathrm{s})$ \\
\hline cubic meter per second $\left(\mathrm{m}^{3} / \mathrm{s}\right)$ & 35.31 & cubic foot per second $\left(\mathrm{ft}^{3} / \mathrm{s}\right)$ \\
\hline \multicolumn{3}{|c|}{ Mass } \\
\hline $\operatorname{gram}(\mathrm{g})$ & 0.03527 & ounce, avoirdupois (oz) \\
\hline kilogram (kg) & 2.205 & pound avoirdupois (lb) \\
\hline
\end{tabular}

To communicate effectively with stakeholders, managers, and other scientists working on the Lower Missouri River, this report uses a mix of U.S. customary units and International System of Units (SI) units of measure. Distances along the Missouri River are given in river miles upstream from the junction with the Mississippi River at St. Louis, Missouri, as measured by the U.S. Army Corps of Engineers in 1960. Discharges are provided in the customary units of cubic feet per second. Reach-scale hydraulic variables — depth and velocity —are in SI units of meters and meters per second.

Temperature in degrees Celsius $\left({ }^{\circ} \mathrm{C}\right)$ may be converted to degrees Fahrenheit $\left({ }^{\circ} \mathrm{F}\right)$ as follows:

$$
{ }^{\circ} \mathrm{F}=\left(1.8 \times^{\circ} \mathrm{C}\right)+32
$$

Vertical coordinate information is referenced to the North American Vertical Datum of 1988 (NAVD 88)

Horizontal coordinate information is referenced to the World Geodetic System of 1984 (WGS 84) 


\title{
Ecological Requirements for Pallid Sturgeon Reproduction and Recruitment in the Lower Missouri River: Annual Report 2009
}

\author{
By Aaron J. DeLonay ${ }^{1}$, Robert B. Jacobson ${ }^{1}$, Diana M. Papoulias ${ }^{1}$, Mark. L. Wildhaber ${ }^{1}$, Kimberly A. \\ Chojnacki', Emily K. Pherigo ${ }^{1}$, Casey L. Berthold ${ }^{2}$, and Gerald E. Mest $\left.\right|^{2}$
}

\section{Abstract}

The Comprehensive Sturgeon Research Project is a multiyear, multiagency collaborative research framework developed to provide information to support pallid sturgeon recovery and Missouri River management decisions. The general Comprehensive Sturgeon Research Project strategy is to integrate field and laboratory studies of sturgeon reproductive ecology, habitat requirements, and physiology to produce a predictive understanding of sturgeon population dynamics. The project scope of work is developed annually with cooperating research partners and in collaboration with the U.S. Army Corps of Engineers, Missouri River Recovery-Integrated Science Program. The research consists of several interdependent and complementary research tasks engaging multiple disciplines that primarily address spawning as a probable limiting factor in reproduction and survival of the pallid sturgeon. The research is multifaceted and is designed to provide information needed for management decisions impacting habitat restoration, flow modification, and pallid sturgeon population augmentation on the Missouri River, and throughout the range of the species. Research activities and progress towards understanding of the species are reported to the U.S. Army Corps of Engineers annually. This annual report details the research effort and progress made by Comprehensive Sturgeon Research Project during 2009.

\section{Introduction}

This report documents research activities under the Comprehensive Sturgeon Research Project (CSRP) for January 1 through December 31,2009 . CSRP is an interagency collaboration of the U.S. Geological Survey (USGS), Nebraska Game and Parks Commission (NGPC), U.S. Fish and Wildlife Service (USFWS), and the U.S. Army Corps of Engineers' Missouri River Recovery - Integrated Science Program. The goal of CSRP is to improve the fundamental understanding of the reproductive ecology of the pallid sturgeon (Scaphirhynchus albus) to better inform river and species management decisions. Specific objectives include:

- Determining movement, habitat-use, and reproductive behavior of pallid sturgeon;

- Understanding reproductive physiology of pallid sturgeon and relations to environmental conditions;

- Determining origin, transport, and fate of drifting pallid sturgeon larvae and evaluate bottlenecks for recruitment of early life stages;

- Quantifying availability and dynamics of aquatic habitats needed by pallid sturgeon for all life stages; and

- Managing databases, integrating understanding, and publishing relevant information into the public domain.

Management actions to increase reproductive success and survival of pallid sturgeon in the Lower Missouri River have been focused on flow regime, channel morphology, and propagation (U.S. Fish and Wildlife Service, 2003). Since 2005, scientists at the USGS have been engaged in an interdisciplinary research program initiated at the request of the U.S. Army Corps of Engineers (USACE). CSRP was designed to assess how different life stages and essential activities of sturgeon respond to a range of ecological factors.

\footnotetext{
${ }^{1}$ U.S. Geological Survey, Columbia Environmental Research Center, Columbia, MO 65201
}

${ }^{2}$ Nebraska Game and Parks Commission, Lincoln, NE 68503 
CSRP has evolved into an interagency collaboration of the USGS, NGPC, USFWS, and the USACE Missouri River Recovery - Integrated Science Program. CSRP research is intended to provide managers with improved understanding of linkages among flow regime, reengineered channel morphology, and pallid sturgeon reproduction and survival.

CSRP direction has been guided by results of sturgeon research workshops convened in 2004 (Quist and others, 2004) and 2007 (Bergman and others, 2008), by hypotheses that emerged about the role of a naturalized flow regime in pallid sturgeon reproduction during a series of workshops in 2005 (Jacobson and Galat, 2008), and by feedback from an independent science review (Sustainable Ecosystems Institute, 2008). Research objectives also have emphasized science information gaps related to priority management issues, including understanding the role of pulsed flow releases from Gavins Point Dam and Fort Peck Dam, and understanding the functions of constructed shallow-water habitat in the sturgeon life cycle.

The CSRP research approach integrates opportunistic field studies, field-based experiments, and controlled laboratory studies. The field study plan is designed to explore the role of flow regime and associated environmental cues using two complementary approaches. An upstreamdownstream approach compares sturgeon reproductive behavior between an upstream section of the Lower Missouri River (fig. 1) with highly altered flow regime and a downstream section that maintains much of its preregulation flow variability (Galat and Lipkin, 2000). The upstream section includes an experimental approach to compare reproductive behavior in years with pulsed flow releases to years without.

\section{Scope of Work}

The 2009 CSRP approved scope of work included four interrelated tasks. Division of CSRP research into tasks was for convenience in understanding the relations among scientific efforts and for budgeting internal to the CSRP; the four tasks presented in 2009 were highly interdependent and designed to provide the maximum information for understanding reproductive ecology of the pallid sturgeon. Tasks for 2009 included:

1. Proposed in collaboration with NGPC to track over 80 pallid sturgeon in the Lower Missouri River to determine behavior during spawning and nonspawning life stages; to do high-frequency intensive tracking on at least two but no more than five reproductive pallid sturgeon in each of two river segments, depending on availability of fish; and to increase emphasis on spawning verification through dual-frequency identification sonar (DIDSON) acoustic camera deployment and larval sampling. The experimental design continues to characterize fish movement in relation to flow, temperature, and turbidity in using upstream and downstream sections of the river for comparison.

2. Coordinated physiological studies on tracked fish to develop critical links between environment (for example, flow pulses, turbidity, and temperature) and reproductive readiness will be continued. The nature of these linkages will ultimately show the extent to which flow management can affect reproduction of pallid sturgeon. The proposed research included developing understanding of (a) how environmental variability may act as a reproductive cue or as a source of stress that inhibits reproduction and (b) multi-year processes that may act to set up a fish's reproductive physiology and success.

3. Proposed in coordinated habitat studies to employ a new, high-resolution mapping protocol to assess demonstrated spawning patches as well as other habitats that may be limiting to reproduction and survival of the pallid sturgeon. This research was intended to provide a uniquely detailed understanding of spawning habitat in the river and to address how migration pathways may energetically limit pallid sturgeon reproduction.

4. Integrated database management aspects for all tasks, outreach efforts, and report production will be continued as critical aspects of the CSRP. A major effort in 2009 was directed at analyzing, writing, and publishing results from previous years so peerreviewed scientific information would be available in the public domain to inform management decisions (DeLonay and others, 2009).

The 2009 scope of work was followed with only minor deviations. The number of reproductive pallid sturgeon that were available for telemetry studies was limited to eight (two females, six males) because of difficulties in catching reproductive fish early in the spring. Opportunities to characterize habitats during spawning migrations were limited because pallid sturgeon in reproductive condition rarely were encountered and implanted late in the spawning season. Reproductive adults migrated only short distances after implantation and spawning occurred soon after tagging. Efforts to capture larval fish downstream from spawning patches were limited by high water and unsafe boating conditions.

\section{Hydroclimatic Conditions During 2009 Field Work}

Runoff during water year 2009 upstream from Gavins Point Dam (October 2008 - September 2009) was 133 percent 

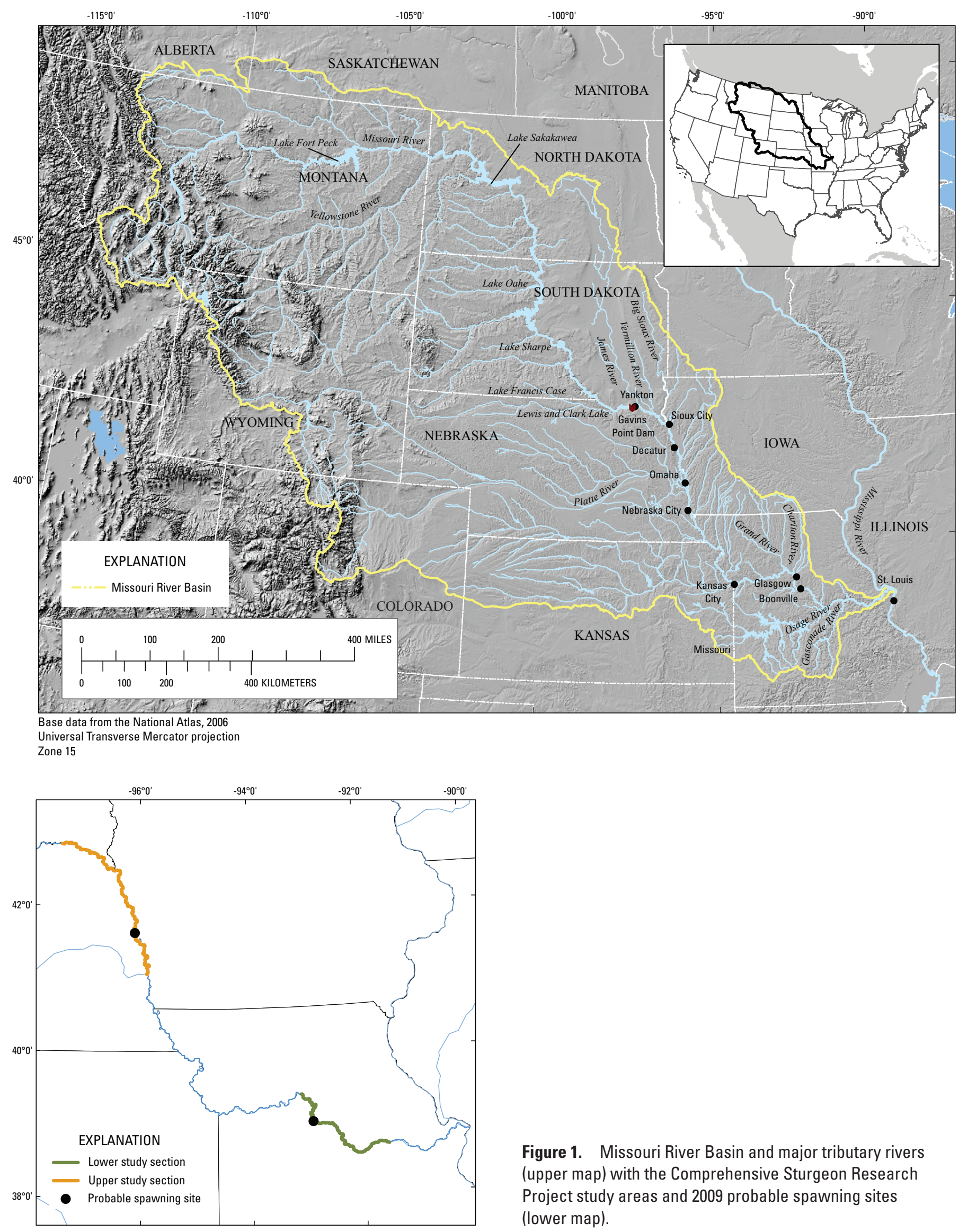

Figure 1. Missouri River Basin and major tributary rivers (upper map) with the Comprehensive Sturgeon Research Project study areas and 2009 probable spawning sites (lower map). 
of average. Reservoir levels were considered sufficient to provide for pulsed-flow releases ${ }^{1}$ from Gavins Point Dam to support spring rises in March and May for sturgeon (U.S. Army Corps of Engineers, 2008). The March 2009 pulsedflow release was cancelled, however, because of high rainfall forecast for the Missouri River Basin in the vicinity of Kansas City, Mo. Although there was no intentional pulsedflow release from Gavins Point Dam to support sturgeon reproduction, the late-March increase in discharge released from the dam to support navigation created a modest spring rise (fig. 2). Discharges from the dam increased by 3,000 cubic feet per day $\left(\mathrm{ft}^{3} / \mathrm{s}\right)$ per day for 2 days and $2,000 \mathrm{ft}^{3} / \mathrm{s}$ on the third day from $11,000 \mathrm{ft}^{3} / \mathrm{s}$ on March 18 to $19,000 \mathrm{ft}^{3} / \mathrm{s}$ on March 20, 2009. Beginning on March 24, the release was reduced over the next 4 days to $15,500 \mathrm{ft}^{3} / \mathrm{s}$ after which it increased over the next 5 days to $18,000 \mathrm{ft}^{3} / \mathrm{s}$ (fig. 2). A May pulsed release from Gavins Point Dam was provided by the Corps of Engineers beginning about May 17. The pulsed release consisted of an increase of $6,000 \mathrm{ft}^{3} / \mathrm{s}$ over the prevailing discharge of about $17,000 \mathrm{ft}^{3} / \mathrm{s}$. The pulse was held at $23,000 \mathrm{ft}^{3} / \mathrm{s}$ for 2 days and then decreased over 7 days to $17,000 \mathrm{ft}^{3} / \mathrm{s}$. The May pulsed release from Gavins Point Dam was largely attenuated downstream from the Platte River, Nebr., resulting in only a relatively small rise. Water releases from Gavins Point Dam and discharges in the Missouri River upstream from the Kansas River were steady and somewhat above average for the remainder of the year. Storage in the reservoir system was sufficient to support full navigationseason releases from Gavins Point Dam from July 1 to December 1.

Discharges were relatively high and highly variable on the Missouri River downstream from the Kansas River (fig. 2). Eight separate natural flow pulses in excess of $50,000 \mathrm{ft}^{3} / \mathrm{s}$ occurred between January 1 and December 1, 2009. Peak

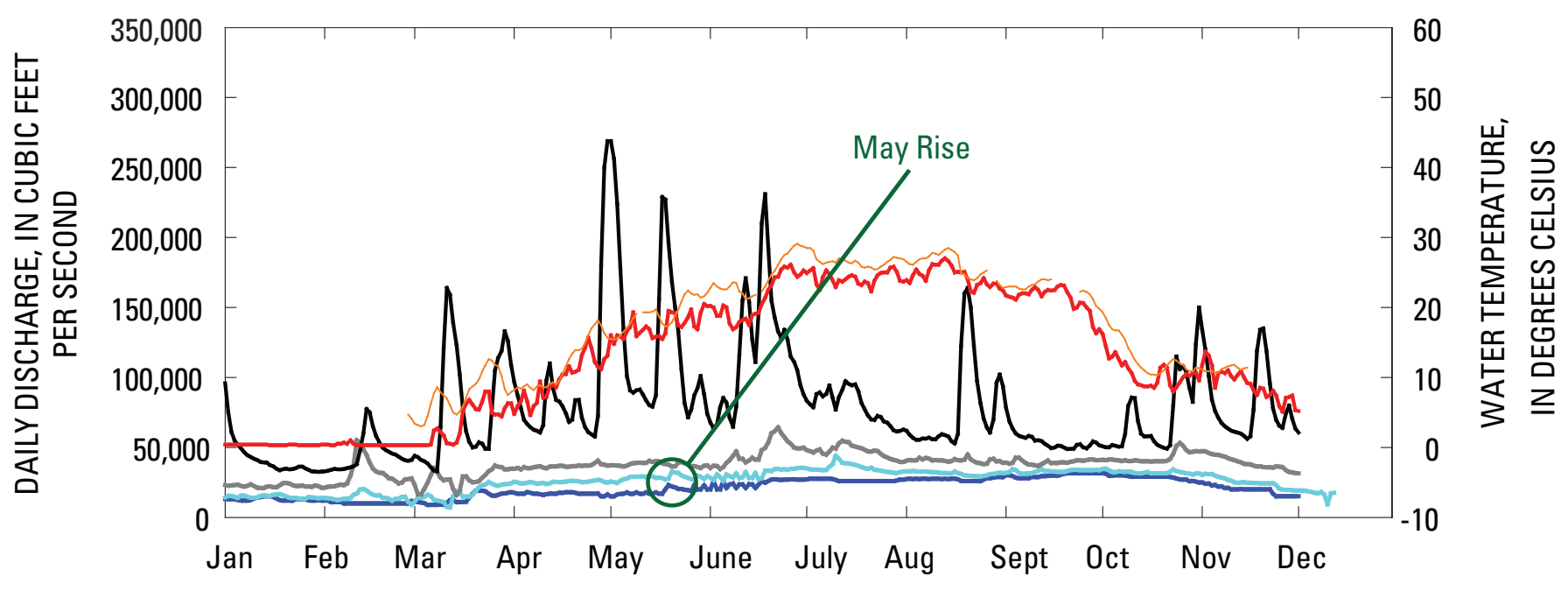

\section{River Discharges}

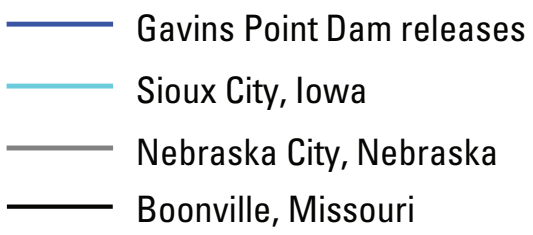

Water Temperatures

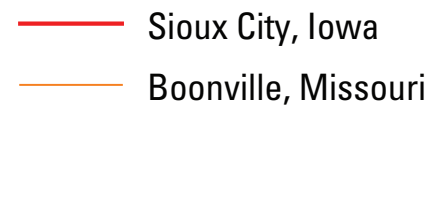

Figure 2. 2009 Lower Missouri River hydrograph with water temperature. Data from U.S. Geological Survey National Water Information System (NWIS), available at http://waterdata.usgs.gov/nwis.

\footnotetext{
${ }^{1}$ Standardized environmental hydrology vocabulary has been established by The Nature Conservancy and implemented worldwide (Mathews and Richter, 2007; Richter and Thomas, 2007). In this vocabulary, a pulse is any short-term, wave-like increase and fall of river discharge, whether natural or arising from an intentional reservoir release. To differentiate between natural and intentional pulsed releases, pulsed-flow release was used to describe the latter. The term spring rise was used to describe any increase in discharge over prevailing low-water discharge; the concept of spring rise includes natural pulses, pulsed-flow releases, and step-like increases to a sustained discharge like those used to support navigation.
} 
discharge at Boonville, Missouri, occurred April 30 and May 1 and equaled 269,000 ft $33 / \mathrm{s}$ between a 2- and 5-year returninterval flood. Floods in mid-May and mid-June were at or above a 2-year return-interval discharge. Because of the concentration of rainfall in tributaries downstream from the Platte River during 2009, the upstream sample of tagged fish experienced much less hydrologic variability-fewer and substantially smaller pulses - than the downstream sample (fig. 2).

\section{Accomplishments and Products}

A CSRP report published in 2009 synthesized 4 years of field and experimental information on sturgeon reproductive ecology (DeLonay and others, 2009). The report concluded that converging lines of evidence support the hypothesis that maturation and readiness to spawn in female sturgeon is set up many months before spawning, likely cued by day length. Moreover, data collected during 2005-08 indicated that among suspected short-term cues for ovulationwater temperature, water discharge, and day of year — only water temperature had a consistent relation to reproductive indicators and spawning behaviors. This support is based on tracking records, reproductive physiology data, and habitat-use information for hundreds of reproductive shovelnose sturgeon (Scaphirhynchus platorynchus), but only six gravid pallid sturgeon that were tracked in 2007 and 2008. Moreover, field studies were conducted during 4 years with extremely variable hydrology that precluded well-controlled field experiments (DeLonay and others, 2009). Results of reproductive pallid sturgeon tracked in 2009 tend to support our 200508 results, but numbers of fish studied are still relatively small, behavioral variability is large, and, therefore, the replication achieved through 2009 is unlikely to be considered scientifically definitive. Increased certainty in understanding the environmental factors that support reproduction of pallid sturgeon will require additional replications of detailed field studies, well-controlled field experiments (for example, pulsed flow modifications from Gavins Point Dam), and focused laboratory studies.

Data synthesized and reported from 2005-08 (DeLonay and others, 2009) and new information from 2009 show consistent patterns of upstream spawning migrations in which sturgeon appear to be spawning at many locations and over a period of 1 to 2 months. Movement patterns vary between sexes. Female sturgeon generally move upstream and appear to spawn at the apex of their migration, whereas, males migrate upstream to one or several spawning locations or remain relatively sedentary. Environmental changes, such as temperature fluctuations or extreme flow events, may slow or disrupt spawning migrations or inhibit spawning. Limited information indicates that patterns of migratory behavior of pallid sturgeon are similar to shovelnose sturgeon. Although information collected during 2009 is consistent with the 2005-08 data, additional information will narrow the time period, spatial extent, and range of environmental conditions associated with successful spawning.

Spawning habitats documented during 2009 support results from 2005-08 and serve to narrow and quantify spawning conditions. Similar to results in 2008, the 2009 spawning habitat patch documented in the downstream section was on the outside of a revetted bend, with deep (greater than 3 meters $(\mathrm{m})$ ), relatively fast (greater than 1 meter per second $(\mathrm{m} / \mathrm{s}))$, and turbulent flow. In the upstream section, spawning movements were highly variable. Two habitat patches were identified from movements of one female, but spawning was not verified and it is not clear at which site spawning occurred. Coincidently, the locations on the upper river were not as clearly associated with the fastest, deepest available water. If revetted outside bends are confirmed as habitats conducive to successful spawning, it would follow that spawning habitat may not be a limiting factor in pallid sturgeon reproduction in the Lower Missouri River. Habitat studies in 2009 also characterized a limited number of fish during upstream migration. In contrast to spawning sturgeon, these data support the hypothesis that migrating sturgeon utilize lower velocity habitats on inside bends, presumably to minimize energy expenditure (Reuter and others, 2009). Channel modifications that impede or slow migration may influence the location, timing, and synchronization of aggregation and spawning. Increased energy expenditure during upstream migration may reduce a fish's reproductive capacity. Additional coordinated tracking, habitat assessments, and physiological studies could indicate whether channel reengineering of the Lower Missouri River could increase low-energy migration pathways and increase reproductive success.

During 2009, project scientists published results in several venues and presented results at many regional, national, and international scientific meetings. Project scientists also provided input into management discussions numerous times at the request of the USACE, other Federal and State agencies, and stakeholders.

The most extensive accomplishment in 2009 was the 2008 annual project report (DeLonay and others, 2009). At the request of the Missouri River Recovery - Integrated Science Program, the 2008 report was expanded into a 4-year synthesis. Because of the scope and potential importance, the report was published as a U.S. Geological Survey Scientific Investigations Report and received broad and detailed technical and editorial reviews. This additional effort delayed publication until fall of 2009. Additional products delivered or published during 2009 are in the following table. 
Table 1. Missouri River Sturgeon Project Products, U.S. Geological Survey Columbia Environmental Research Center, 2009.

\begin{tabular}{|c|c|}
\hline & $\begin{array}{l}\text { Publications } \\
\text { (alphabetical order by author last name) }\end{array}$ \\
\hline Author & Title \\
\hline $\begin{array}{l}\text { Braaten, P.J., Fuller, D.B., Lott, R.D., and } \\
\text { Jordan, G.R. }\end{array}$ & $\begin{array}{l}\text { An estimate of the historic population size of } \\
\text { adult pallid sturgeon in the upper Missouri } \\
\text { River Basin, Montana and North Dakota }\end{array}$ \\
\hline $\begin{array}{l}\text { DeLonay, A.J., Jacobson, R.B., Papoulias, } \\
\text { D.M., Simpkins, D.G., Wildhaber, M.L., } \\
\text { Reuter, J.M., Bonnot, T.W., Chojnacki, } \\
\text { K.A., Mestl, G.E., and Mac, M.J. }\end{array}$ & $\begin{array}{l}\text { Ecological requirements for pallid sturgeon } \\
\text { reproduction and recruitment in the Lower } \\
\text { Missouri River-A research synthesis } \\
\text { 2005-08 }\end{array}$ \\
\hline $\begin{array}{l}\text { Elliott, C.M., Reuter, J.M., and Jacobson, } \\
\text { R.B. }\end{array}$ & $\begin{array}{l}\text { Channel morphodynamics in four reaches of } \\
\text { the Lower Missouri River, 2006-07 }\end{array}$ \\
\hline $\begin{array}{l}\text { Elliott, C.M., Huhmann, B.L., and Jacobson, } \\
\text { R.B. }\end{array}$ & $\begin{array}{l}\text { Geomorphic classification of the Lower } \\
\text { Platte River, Nebraska }\end{array}$ \\
\hline $\begin{array}{l}\text { Guy, C.S., Braaten, P.J., Herzog, D.P., Pitlo, } \\
\text { J. and Rogers, R.S. }\end{array}$ & $\begin{array}{l}\text { Warmwater fish in rivers in Bonar, S.A., } \\
\text { Hubert, W.A., and Willis, D.W., eds., } \\
\text { Standard methods for sampling North } \\
\text { American freshwater fishes }\end{array}$ \\
\hline $\begin{array}{l}\text { Holan, S.H., Davis, G.M., Wildhaber, M.L., } \\
\text { DeLonay, A.J., and Papoulias, D.M. }\end{array}$ & $\begin{array}{l}\text { Hierarchical Bayesian Markov switching } \\
\text { models with application to predicting } \\
\text { spawning success of shovelnose sturgeon. }\end{array}$ \\
\hline $\begin{array}{l}\text { Jacobson, R.B., Blevins, D.W., and Bitner, } \\
\text { C.J. }\end{array}$ & $\begin{array}{l}\text { Sediment regime constraints on river } \\
\text { restoration-An example from the } \\
\text { Lower Missouri River, in James, L.A., } \\
\text { Rathburn, S.L., and Whittecar, G.R. eds., } \\
\text { Management and restoration of fluvial } \\
\text { systems with broad historical changes and } \\
\text { human impacts }\end{array}$ \\
\hline $\begin{array}{l}\text { Jacobson, R.B., Johnson, H.E., III, and } \\
\text { Dietsch, B.J. }\end{array}$ & $\begin{array}{l}\text { Hydrodynamic simulations of physical } \\
\text { aquatic habitat availability for pallid } \\
\text { sturgeon in the Lower Missouri River, at } \\
\text { Yankton, South Dakota, Kenslers Bend, } \\
\text { Nebraska, Little Sioux, Iowa, and Miami, } \\
\text { Missouri, 2006-07 }\end{array}$ \\
\hline $\begin{array}{l}\text { Reuter, J.M., Jacobson, R.B., Elliott, C.M., } \\
\text { and DeLonay, A.J. }\end{array}$ & $\begin{array}{l}\text { Assessment of Lower Missouri River } \\
\text { physical aquatic habitat and its use by } \\
\text { adult sturgeon (genus Scaphirhynchus) } \\
\text { 2005-07 }\end{array}$ \\
\hline
\end{tabular}

U.S. Geological Survey Scientific Investigations Report 2009-5074, 258 p.

U.S. Geological Survey Scientific Investigations Report 2009-5198, 29 p.

American Fisheries Society, Bethesda, Md., August, 2009, p. 59-84.

Journal of the Royal Statistical Society: Series C (Applied Statistics). 2009, 58, Part 1, pp. 1-18.

Geological Society of America Special Paper 451 , p. 1-22, Contact R.B. Jacobson at rjacobson@usgs.gov

\section{U.S. Geological Survey, Scientific} Investigations Report 2009-5058, 67 p.,

\section{U.S. Geological Survey Scientific Investigations Report 2009-5121, 81 p.}

\section{Bryan, J.L., M.L. Wildhaber, D.Gladish, S.
Holan, M. Ellersieck}

\section{Agency Reports}

The power to detect trends in Missouri River fish populations within the Pallid Sturgeon Population Assessment Program.

\section{Presentations (ordered by date with oldest first)}

Kruse, C., M.R.,Drobish, T.L, Welker M.P., Ruggles, T. Haddix, S. Krentz, R.Wilson, R. Klumb, D. Shuman, S.Stukel, S.LaBay, J. Kral, K. Steffensen, G.E. Mestl, P. Horner, D. Niswonger, W.J. Doyle, A Plauck, T.D. Hill, and M.L. Wildhaber
Standardized pallid sturgeon and fish community monitoring in the Missouri River Basin.

\section{9}

Administrative Report, 419 p. River Basin.

Integrating ArcPad, ArcGIS and SQL Server for data collection and management to support sturgeon research on the Lower Missouri

\section{February 2-4, 2009}

Annual Meeting of the Minnesota Chapter of the American Fisheries Society, Duluth, Minn.

March 18, 2009

Mid-Missouri GIS Users Group Meeting, Columbia, Mo. 
Table 1. Missouri River Sturgeon Project Products, U.S. Geological Survey Columbia Environmental Research Center, 2009.—Continued

\begin{tabular}{l}
\hline \multicolumn{1}{c}{ Author } \\
\hline Chojnacki, K.A., and DeLonay, A.J. \\
Braaten, P.J., Lott, R.D., Fuller, D.B., and \\
Ruggles, M.P.
\end{tabular}

Chojnacki, K.A. and DeLonay, A.J.

DeLonay, A.J., Papoulias, D.M., Wildhaber, M.L., Jacobson, R.B., Chojnacki, K.A., Mestl, G.E., and Bergthold, C.L.

Jacobson, R.B., Elliott, C.M., and Reuter, J.M.

Papoulias, D.M, Annis, M., DeLonay, A.J., Gale, R., and Tillitt, D.E.

Jacobson, R.B.

Papoulias, D.M.

Jacobson, R.B., Elliott, C.M., and Reuter, J.M.

Braaten, P.J. and Fuller, D.B.

Wildhaber, M.L., DeLonay, A. J., Papoulias, D. M., Holan S.H., Davis, G.M., and Sommerhauser, D.K.

Mac, M.J.

Bergthold, C.L., Chojnacki, K.A., Delonay, A.J., Mestl, G.F.

Braaten, P., Fuller, D., Lott, R., Ruggles, M.

DeLonay, A.J., Papoulias, D.M, Wildhaber, M.L., Jacobson, R.B., Chojnacki, K.A., Mestl, G.E., Bergthold, C.L.

$\begin{array}{cc}\text { Title } & \text { Source } \\ \text { Presentations } & \\ \text { (ordered by date with oldest first)—Continued } & \end{array}$

Mobile mapping and electronic data

March 18, 2009

collection to track pallid sturgeon in the

Lower Missouri River

Mid-Missouri GIS Users Group Meeting, Columbia, Mo.

Fort Peck flow modification biological data collection plan: Utility of a multi-year data set for quantifying annual recruitment variations in pallid and shovelnose sturgeon

Application of mobile mapping and electronic data collection in the field to track pallid sturgeon in the Lower Missouri River

Spawning migration, habitat use and behavior of pallid sturgeon in the Lower Missouri River

Defining and employing reference conditions for ecological restoration of the Lower Missouri River

Contaminants in the tissues of sturgeon from the Missouri River and the intersex in male sturgeon

Water wars on the big Muddy: Reengineering the Lower Missouri River for ecosystem recovery

Missouri River sturgeon reproductive problems

Habitat dynamics on the Lower Missouri River: The physical template for pallid sturgeon recovery

Pallid sturgeon studies in the Missouri River below Fort Peck Dam

Spawning migration patterns of sturgeons in a modified and heavily regulated large river.

Independent science review: What, how, and why

Seasonal movements and habitat use of adult pallid sturgeon in the lower Missouri River, USA

Drift dynamics of larval pallid sturgeon in the mainstem Missouri River: Inferences for the lack of recruitment in fragmented river reaches

Spawning migration, habitat use and behavior of pallid sturgeon in the Lower Missouri River
March 24-27, 2009

Missouri River Natural Resources Mont.

\section{March 24-27, 2009}

Missouri River Natural Resources Conference \& BiOp Forum, Billings, Mont.

March 24-27, 2009

Missouri River Natural Resources Conference \& BiOp Forum, Billings, Mont.

\section{March 24-27, 2009}

Missouri River Natural Resources Conference \& BiOp Forum, Billings, Mont.

March 24-27, 2009

Missouri River Natural Resources Mont.

April 1, 2009

Missouri Conservation Engineers Meeting Columbia, Mo.

\section{April 4, 2009}

Veterinary School, University of Missouri Columbia, Mo.

April 9, 2009

USGS Missouri River Science Symposium Columbia, Mo.

\section{May 5, 2009}

Missouri River Recovery Meeting, Fort Peck, Mont.

June 22-26, 2009

46th Annual Animal Behavior Society Meeting Pirenopolis, Brazil

\section{July 21, 2009}

Missouri River Recovery Implementation Committee Meeting, Pierre, S. Dak.

\section{August 31-September 3, 2009}

139th Annual American Fisheries Society Conference, Nashville, Tenn.

August 31-September 3, 2009

139th Annual American Fisheries Society Conference, Nashville, Tenn.

August 31-September 3, 2009

139th Annual American Fisheries Society Conference, Nashville, Tenn. Conference \& BiOp Forum, Billings, Conference \& BiOp Forum, Billings, 
Table 1. Missouri River Sturgeon Project Products, U.S. Geological Survey Columbia Environmental Research Center, 2009.—Continued

\begin{tabular}{|c|c|}
\hline Author & Title \\
\hline & $\begin{array}{c}\text { Presentations } \\
\text { (ordered by date with oldest first)—Continued }\end{array}$ \\
\hline $\begin{array}{l}\text { Heist, E., Braaten, P., Colombo, R., Delonay, } \\
\text { A., Garvey, J., Hartfield, P., Herzog, D., } \\
\text { Jordan, G., Kappenman, K., Webb, M. }\end{array}$ & Status of pallid sturgeon \\
\hline $\begin{array}{l}\text { Bryan, J.L., Wildhaber, M.L., Gladish, D., } \\
\text { Holan, S., Ellersieck, M. }\end{array}$ & $\begin{array}{l}\text { Power to detect trends in shovelnose and } \\
\text { pallid sturgeon populations in the Lower } \\
\text { Missouri River. }\end{array}$ \\
\hline $\begin{array}{l}\text { DeLonay, A.J., Papoulias, D.M., Wildhaber, } \\
\text { M.L., Jacobson, R.B., Chojnacki, K.A., } \\
\text { Mestl, G.E., and Bergthold, C.L. }\end{array}$ & $\begin{array}{l}\text { Spawning migration, habitat use and } \\
\text { behavior of pallid sturgeon in the Lower } \\
\text { Missouri River. }\end{array}$ \\
\hline $\begin{array}{l}\text { Mestl, G.F., Bergthold, C.L., Chojnacki, } \\
\text { K.A., DeLonay, A.J., Bryan, J.L., } \\
\text { Wildhaber, M.L., Bonnot, T.W., and } \\
\text { Millspaugh, J.J. }\end{array}$ & $\begin{array}{l}\text { Resource selection of adult pallid sturgeon } \\
\text { Scaphirhynchus albus in the channelized } \\
\text { Missouri River, USA with implications } \\
\text { for current and planned habitat creation } \\
\text { projects. }\end{array}$ \\
\hline $\begin{array}{l}\text { Wildhaber, M.L., DeLonay, A. J., Papoulias, } \\
\text { D. M., Holan, S.H., Davis, G.M., and } \\
\text { Sommerhauser, D.K. }\end{array}$ & $\begin{array}{l}\text { Spawning migration of shovelnose sturgeon } \\
\text { in the modified and heavily regulated } \\
\text { Lower Missouri River. }\end{array}$ \\
\hline Mac, M.J. & $\begin{array}{l}\text { An experiment with stakeholder influence } \\
\text { on natural resource management: } \\
\text { Missouri River Recovery Implementation } \\
\text { Committee (MRRIC) }\end{array}$ \\
\hline $\begin{array}{l}\text { Lallaman, J.J., Malin, M.I., Vishy, C.J., } \\
\text { DeLonay, A.J., Galat, D.L. }\end{array}$ & $\begin{array}{l}\text { Use of three different acoustic gears to assess } \\
\text { paddlefish abundance and distribution in } \\
\text { the Osage River, Mo. }\end{array}$ \\
\hline
\end{tabular}

Heist, E., Braaten, P., Colombo, R., Delonay, Status of pallid sturgeon A., Garvey, J., Hartfield, P., Herzog, D., Jordan, G., Kappenman, K., Webb, M.

ryan, J.L., Wildhaber, M.L., Gladish, D., Holan, S., Ellersieck, M.

eLonay, A.J., Papoulias, D.M., Wildhaber, M.L., Jacobson, R.B., Chojnacki, K.A.,

K.A., DeLonay, A.J., Bryan, J.L., Wildhaber, M.L., Bonnot, T.W., and

Wildhaber, M.L., DeLonay, A. J., Papoulias, D. M., Holan, S.H., Davis, G.M., and . . .

\section{Posters \\ (ordered by date with oldest first)}

Arab, A., Wikle, C.K., Wildhaber, M.L., and DeLonay, A.J.

Chojnacki, K.A., and DeLonay, A.J.

Bazzetta, L., and Jacobson, R.B.

Candrl, J.S., Papoulias, D.M., and Tillitt, D.E.

Kunz, E.K., Haas, J.D., Ruskamp, R.L., Adams, J.D., and DeLonay, A.J.

Vishy, C.J., Combs, D.K., and DeLonay, A.J.
A hierarchical bayesian modeling approach for analysis of large river fish movement data. for data collection and management: research of sturgeon on the Lower Missouri River

Vegetation dynamics in a constructed shallow-water habitat project, Lower Missouri River, June 2005-June 2008

The point of no return in first-feeding pallid sturgeon larvae

Targeted capture of pallid sturgeon in two study areas of the Missouri River below Gavins Point Dam

Deployment techniques to overcome challenges to the application of dual frequency identification sonar (DIDON) for monitoring fish in the Lower Missouri River
Integrating ArcPad, ArcGIS and SQL Server
August 31-September 3, 2009

139th Annual American Fisheries Society Conference, Nashville, Tenn.

October 26-29, 2009

6th International Sturgeon Symposium, Wuhan, Hubei Province, China

October 26-29, 2009

6th International Sturgeon Symposium, Wuhan, Hubei Province, China

October 26-29, 2009

6th International Sturgeon Symposium, Wuhan, Hubei Province, China

October 26-29, 2009

6th International Sturgeon Symposium, Wuhan, Hubei Province, China

October 30, 2009

Charles Schwarz Seminar Series, University of Missouri, Columbia, Mo.

December 6-9, 2009

70th Midwest Fish and Wildlife Conference, Springfield, Ill.

\section{January 13-15, 2009}

Eigth Annual Hawaii International Conference on Statistics, Mathematics and Related Fields, Honolulu, Hawaii

\section{February 16-18, 2009}

2009 Missouri GIS Conference, Osage Beach, Mo.

\section{March 24-27, 2009}

Missouri River Natural Resources Conference \& BiOp Forum, Billings, Mont.

March 24-27, 2009

Missouri River Natural Resources Conference \& BiOp Forum, Billings, Mont.

March 24-27, 2009

Missouri River Natural Resources Conference \& BiOp Forum, Billings, Mont.

March 24-27, 2009

Missouri River Natural Resources Conference \& BiOp Forum, Billings, Mont. 
Table 1. Missouri River Sturgeon Project Products, U.S. Geological Survey Columbia Environmental Research Center, 2009.—Continued

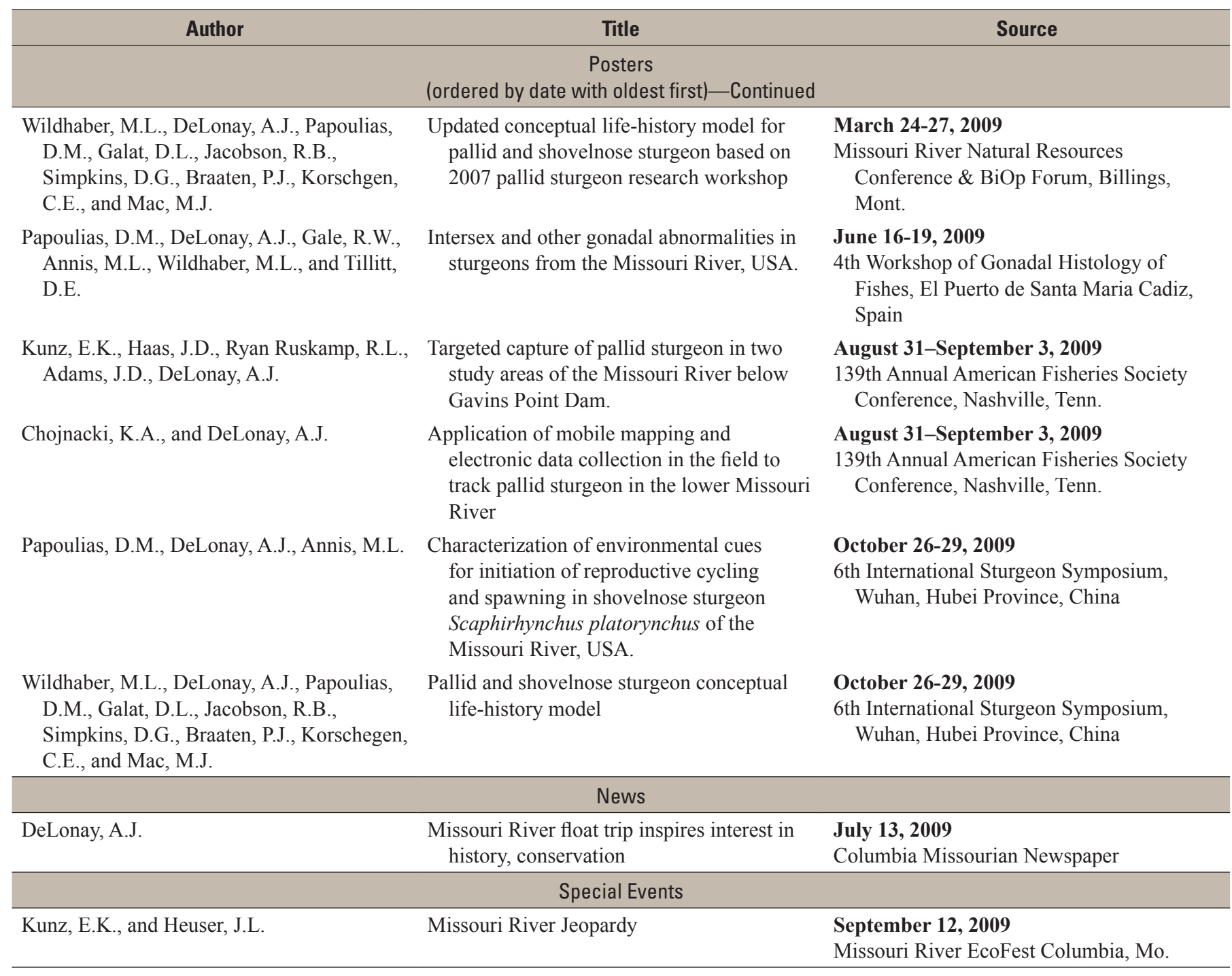




\section{Future Research into Reproductive Ecology of Missouri River Pallid Sturgeon}

During 2009, the CSRP was successful in adding replication and greater detail to existing understanding of pallid sturgeon reproductive ecology, especially related to spawning behavior and spawning habitat. Information on environmental conditions, migrations, and reproductive physiology added additional data points to the understanding of reproductive cues and the potential role of pulsed flow reservoir releases. While 2009 data supported the growing set of information on links between potential management actions and prospects for reproduction and survival of the species, additional information gaps have become more apparent. Continued studies and new research opportunities can provide information to close these gaps. These efforts include:

1. Replicating controlled and opportunistic field experiments on spawning cues to achieve credibility within the scientific community. Credibility will probably require several additional years of field studies at the current level of effort (four to eight reproductive pallid sturgeon per year) assuming good representation of years with and without flow pulses. Alternatively, fewer years would be necessary with greater numbers of tagged fish and the resources to track them. Coordinated physiological and habitat studies are needed to understand the causal links between environmental conditions and reproductive success.

2. Increasing effort in addressing spawning success criteria. In addition to demonstrating that eggs have been released, indicators of spawning success are the presence of males, observations of fish interaction, observations or sampling of fertile eggs, sampling of larvae downstream from demonstrated spawning patches, and sampling of larvae of a developmental stage consistent with the observed spawning event or linked by genetic analysis.

3. Understanding where pallid sturgeon go and habitats used between reproductive seasons. Pallid sturgeon females become reproductive once every 2-5 years, and environmental conditions between spawning events may be critical to spawning success. This will require additional year-round tracking and may require expansion of telemetry efforts into the Mississippi River. Such efforts will also help define the extent of habitat used by these fish and may provide insight into genetic structure of the population.

4. Continuing studies of intersex and reproductive tumors (DeLonay and others, 2009) in pallid sturgeon to determine whether contaminants in the environment contribute to lack of reproduction or recruitment. Understanding the potential role of reproductive impairment in maturation, migration, fecundity, spawning behavior, gamete quality, viability, fertilization, and hatching success will help management agencies to assess the consequences of intersex in the context of a highly altered and intensively managed river.

5. Quantifying habitat selection during nonreproductive seasons and for juvenile fish to determine if other habitats (for example, migration, over-wintering, or young-of-the-year feeding habitats) are bottlenecks on reproduction and recruitment. This can be approached through a combination of detailed field studies and controlled laboratory experiments.

6. Improving understanding of transport and fate of pallid sturgeon larvae to determine if they successfully drift into supportive habitats. Previously presented calculations have shown that mean velocities in the Lower Missouri River are sufficient to transport larvae hatched over much of its length into the Middle Mississippi River. Improved understanding of drift dynamics will document whether channel reengineering that decreases mean velocity and increases drift retention would be effective in increasing recruitment.

\section{Detailed Research Task Activities and Progress}

\author{
Task 1. Movement, Habitat Use, and \\ Reproductive Behavior of Shovelnose Sturgeon \\ and Pallid Sturgeon in the Lower Missouri River
}

\section{Background}

Numerous studies have examined habitat use and movement by Scaphirhynchus sturgeon (Hurley and others, 1987; Latka and others, 1995; Quist and others, 1999; DeLonay and others, 2000; Bramblett and White, 2001; Snook and Peters, 2002; Hurley and others, 2004; Garvey and others, 2009). Few of these studies have reported the reproductive status of the fish studied or followed the fish to assess whether those in reproductive condition spawned successfully. None have precisely documented where sturgeon spawn or provided information necessary to link sturgeon migration, spawning, or reproductive success to large river management. Until very 
recently none have specifically focused on reproductively mature fish prior to and during the spawning season.

During 2004-08, telemetry was employed on the Missouri River to relocate individual sturgeon to collect information on movement, habitat use, behavior, and response to environmental cues or habitat manipulations (DeLonay and others, 2007b; DeLonay and others, 2009). Effective use of telemetry also afforded the opportunity to recollect, reassess, and reimplant individual sturgeon to monitor changes in growth, condition, and reproductive status over time. Through intensive tracking of telemetry tagged fish, characteristic migration patterns of reproductive sturgeon have been defined, and spawning locations have been identified (DeLonay and others, 2009). Deployment of environmental data storage tags (DST) in telemetered fish has provided unprecedented direct and quantitative understanding of a fish's environment (DeLonay and others 2007a; Holan and others 2009). Activities conducted under Task 1 are part of a unique multidisciplinary approach in which telemetry is coordinated with physiological assessments of reproductive behavior (Task 2) and hydroacoustic habitat assessments (Task 3) (DeLonay and others, 2007b; DeLonay and others, 2009). The physiologic context provides an understanding of the reproductive state of a tagged fish, and, thereby, provides interpretation of fish behavior (Wildhaber and others, 2007). Similarly, detailed habitat mapping around tagged fish places fish behavior within a larger spatial context that allows researchers to characterize habitat availability and selection, and, thereby, understand how channel morphology and flow regime can be managed to maximize reproduction and survival (Reuter and others, 2008; DeLonay and others, 2009; Jacobson and others, 2009; Reuter and others, 2009; Bonnot and others, University of Missouri, Columbia, Mo., written commun., 2009).

\section{Scope and Objectives}

Task 1 is ongoing and a continuation of work initiated in 2005 in collaboration with the NGPC. The objectives of this work are to (1) identify prespawning habitat; (2) determine the direction and magnitude of spawning movements; (3) characterize patterns of habitat use during spawning migrations; (4) determine where and under what conditions sturgeon spawn; (5) verify and validate spawning behavior; (6) assess the relative success of spawning related to status and environmental conditions, including natural and augmented spring flows; and (7) determine and characterize postspawn and nonreproductive habitat.

\section{Methods}

Task 1 focused exclusively on pallid sturgeon in 2009. The work was conducted again within two geographically and hydrologically distinct sections of the Lower Missouri River to take advantage of the longitudinal variability in the system for comparative purposes. One section is located on the Lower Missouri River between the Osage River and Grand River (river miles 130-250). The other section is located between the Platte River in Nebraska and the Big Sioux River (river miles 595-734). The general approach entailed capturing pallid sturgeon from the Missouri River, intensively evaluating the reproductive status of individual sturgeon (in coordination with task 2), instrumenting each with an acoustic transmitter and a data storage tag, tracking their movements, and documenting habitat use (DeLonay and others, 2007b). Pallid sturgeon in reproductive condition were tracked intensively through the spawning period and attempts were made to recover them immediately after spawning to evaluate their reproductive success and recover the DST.

In 2009, USGS planned to implant and track female and male pallid sturgeon to meet established implantation criteria (appropriate size and reproductive status) in each of two study sections with 2-year acoustic transmitters and DSTs recording depth and temperature at 15-minute intervals. At least two, but no more than five, gravid females were targeted for implantation within each section. Throughout the study, concerted efforts were made to recollect, reevaluate, and reimplant pallid sturgeon telemetered in previous years. Following implantation, crews located and tracked individual telemetered fish to record habitat use and seasonal movements (DeLonay and others 2007b). Fish were tracked extensively (located every few days) during pre- and postspawn periods. Fish in reproductive condition were tracked intensively (located daily or several times daily) from April through July, or until recollection indicated that spawning was complete. The goal for gravid female pallid sturgeon was to determine their location each day in early spring, and more frequently when water temperatures reached $16^{\circ} \mathrm{C}$ or when movement or behavior indicated that spawning was imminent. During high-frequency intensive tracking, females are contacted several times daily to determine direction and rate of movement. Upstream migrating females that pause or stop in their migratory movement for more than 6 hours are targeted for continuous monitoring and habitat characterization. Continuous tracking of rapidly migrating sturgeon is not possible during hours of darkness in the lower study section because of safety concerns, but continuous tracking of stationary sturgeon or sturgeon at spawning locations is possible. The goal for nongravid female pallid sturgeon was to determine their location one to three times monthly.

Measurements of water conditions (for example, temperature, conductivity, dissolved oxygen, and turbidity) and habitat characteristics (depth and substrate) were recorded at each location to qualitatively and quantitatively describe habitat used by pallid sturgeon during nonspawning, prespawning, and spawning periods. Detailed mapping of spawning locations was coordinated with task 3 . Suspected spawning locations of transmittered pallid sturgeon were assessed by a combination of sampling for eggs and larvae, capture of adult pallid sturgeon in reproductive condition, or dual-frequency identification sonar (DIDSON) imagery. Not 
all assessment methods were employed at each spawning site. The assessment methods used at each site were determined by resource availability and river conditions.

\section{Results}

USGS and NGPC began sampling for pallid sturgeon in reproductive condition the first week of March 2009 and continued through the third week of April 2009 using trotlines and overnight gill net sets (DeLonay 2007b). Trotlines were modified from previous years to reduce stress and mortality to juvenile pallid sturgeon. The hook size was increased from $3 / 0$ to $5 / 0$ to avoid smaller sturgeon. No mortalities of sturgeon were recorded, and total numbers of sturgeon less than 2,000 grams (g) were reduced compared to 2007-08 (fig. 3). While capture incidence of adult pallid sturgeon greater than 2,000 $\mathrm{g}$ was comparable to past years efforts, sturgeon in reproductive condition rarely were encountered. Gravid females were especially rare. Three reproductive males and one gravid female were captured and implanted in each of the lower and the upper study sections (table 2). All sturgeon used in tracking studies are given a unique database identifier, implanted with a transmitter with a unique acoustic
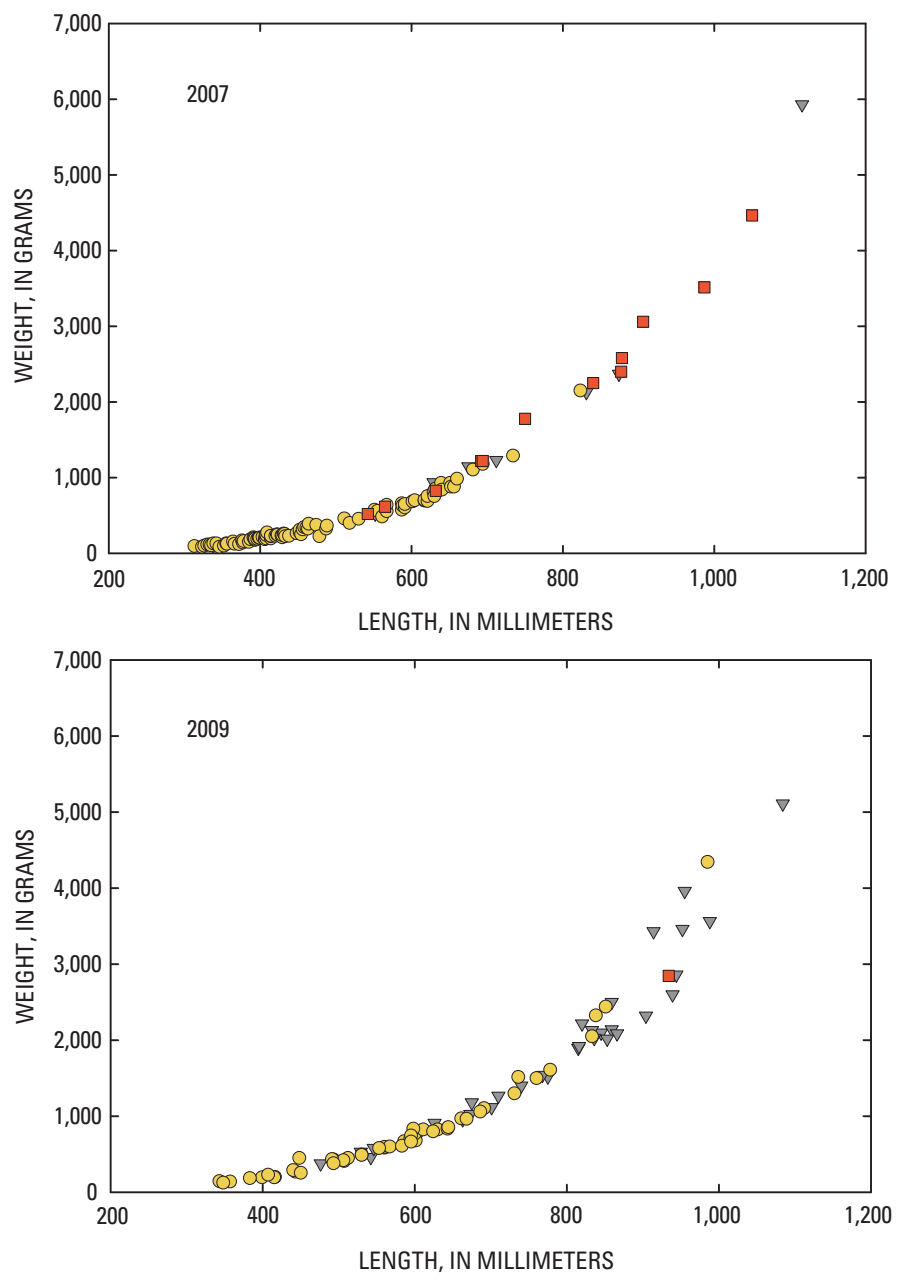

code, and tagged with a passive integrated transponder (PIT) tag. Individual sturgeon can be identified by any of these identification codes. The gravid female in the lower study section (PLS09-007, acoustic code 54500, PIT 472E35150C) was a hatchery-origin marked fish with a coded wire tag. It was captured on April 18, 2009, at river mile 180.0. The upper study section gravid female and all reproductive males from both study sections were unmarked and presumed to be wild pending genetic analysis. The upper study section female (PLS09-009, acoustic code 54604, PIT 48685D0E30) was captured on April 23, 2009, at river mile 666.7. Males and females were surgically implanted with transmitters and DSTs recording temperature and depth (as pressure). The females were implanted with new transmitters containing sensors that emitted real-time depth (as pressure) and motion data. These tags are $1 / 3$ smaller $(60 \times 16$ millimeters $(\mathrm{mm}))$ and transmit at twice the rate of older tags ( 5 seconds). This reduces the impact of surgical procedures close to spawning and facilitates continuous intensive tracking. These smaller tags are shorterlived with battery ratings of less than 180 days. The smaller transmitters are replaced with larger, longer-lived transmitters upon recapture after spawning.

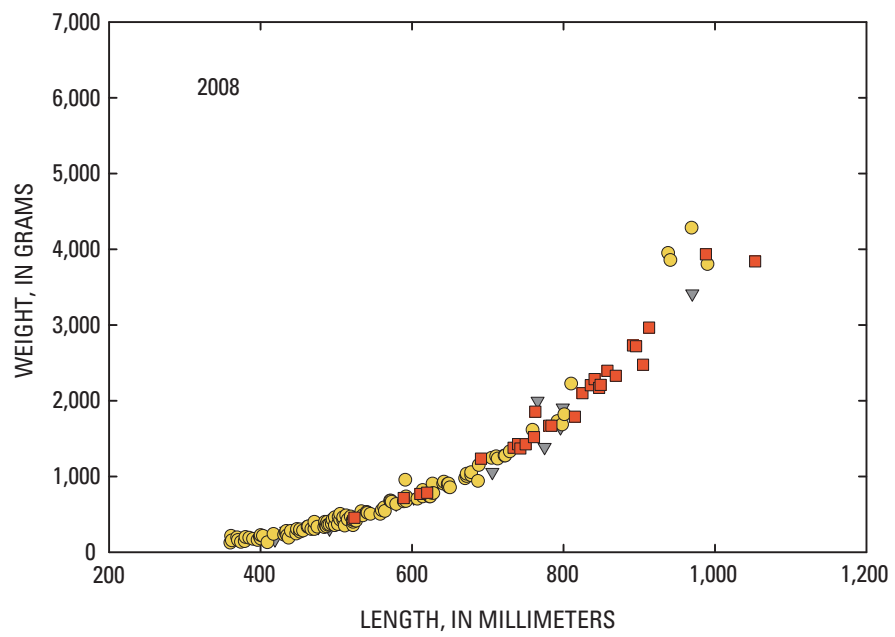

EXPLANATION

$\checkmark$ Unknown

- Hatchery

$\square \quad$ Wild

Figure 3. Length-weight relation of hatchery-released, unknown, and wild pallid sturgeon collected during 2007, 2008, and 2009 spring sampling efforts in both the upper and lower study sections. Pallid sturgeon of unknown origin did not bear hatchery marks and samples have not yet been tested to determine genetic parentage. Pallid sturgeon are presumed wild if genetic testing did not assign them to known broodstock parents. Not all parents used in the propagation program are present in the genetic database; therefore, sturgeon presumed to be wild may be over-represented in the actual totals. 
Table 2. Numbers of pallid sturgeon implanted with transmitters and recaptured in two Lower Missouri River study sections, 2005-09.

[Upper, upper study section; Lower, lower study section; PS, pallid sturgeon; --, no data]

\begin{tabular}{|c|c|c|c|c|c|c|c|c|c|c|c|c|c|c|c|c|c|c|c|c|c|c|c|c|c|c|c|c|c|c|}
\hline \multirow{3}{*}{$\begin{array}{l}\text { Species, gen- } \\
\text { der, and } \\
\text { reproductive } \\
\text { condition }\end{array}$} & \multicolumn{6}{|c|}{2005} & \multicolumn{6}{|c|}{2006} & \multicolumn{6}{|c|}{2007} & \multicolumn{6}{|c|}{2008} & \multicolumn{6}{|c|}{2009} \\
\hline & \multicolumn{3}{|c|}{$\begin{array}{c}\text { Initial } \\
\text { implantation }\end{array}$} & \multicolumn{3}{|c|}{ Recaptured } & \multicolumn{3}{|c|}{$\begin{array}{c}\text { Initial } \\
\text { implantation }\end{array}$} & \multicolumn{3}{|c|}{ Recaptured } & \multicolumn{3}{|c|}{$\begin{array}{c}\text { Initial } \\
\text { implantation }\end{array}$} & \multicolumn{3}{|c|}{ Recaptured } & \multicolumn{3}{|c|}{$\begin{array}{c}\text { Initial } \\
\text { implantation }\end{array}$} & \multicolumn{3}{|c|}{ Recaptured } & \multicolumn{3}{|c|}{$\begin{array}{c}\text { Initial } \\
\text { implantation }\end{array}$} & \multicolumn{3}{|c|}{ Recaptured } \\
\hline & 흠 & 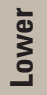 & 흉 & む흠 & ప్ & क्ञँ & 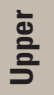 & 㐫 & ฐ্ّ & 흠 & 㐫 & 흉 & 흠 & 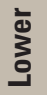 & 흉 & $\begin{array}{l}\text { むু } \\
\text { 음 }\end{array}$ & పే & 흉 & $\begin{array}{l}\frac{\grave{d}}{2} \\
\frac{2}{3}\end{array}$ & 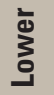 & 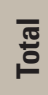 & 흠 & لِّ & ㅍّㅁ & $\begin{array}{l}\text { むু } \\
\frac{0}{g}\end{array}$ & 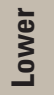 & 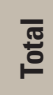 & 흠 & 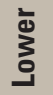 & $\begin{array}{l}\bar{\pi} \\
\text { 으 }\end{array}$ \\
\hline
\end{tabular}

\section{PS female}

reproductive

PS female

non-

reproductive

PS male

reproductive

PS male non-

reproductive

PS unknown

non-

reproductive

PS intersex

Hybrid female reproductive

Hybrid female

non-

reproductive

\begin{tabular}{|c|c|c|c|c|c|c|c|c|c|c|c|c|c|c|c|c|c|c|c|c|c|c|c|c|c|c|c|c|c|c|}
\hline \multicolumn{31}{|c|}{ Summary totals } \\
\hline Pallid sturgeon & 5 & 4 & 9 & -- & -- & -- & 11 & 5 & 16 & -- & -- & -- & 13 & 7 & 20 & 7 & -- & 7 & 41 & 14 & 55 & 14 & 8 & 22 & 6 & 8 & 14 & 12 & 5 & 17 \\
\hline Hybrid & -- & -- & 0 & -- & -- & -- & -- & -- & 0 & -- & -- & -- & -- & -- & 0 & -- & -- & -- & 1 & 1 & 2 & -- & -- & -- & -- & -- & -- & -- & -- & -- \\
\hline
\end{tabular}


Reproductive males and females were tracked with increasing frequency using a pulsed-intensive tracking strategy. Gravid females in each of the study sections were very close to spawning at the time of implantation as indicated by polarization index (PI) measurements. PLS09-007, which had a PI of 0.06 moved upstream steadily after implantation and likely spawned at river mile 206.1-206.5 along outside bend revetment on April 25-26 at water temperatures near $17^{\circ} \mathrm{C}$ (fig. 4). Patterns of movement and behavior during spawning were consistent with observations of females implanted in the lower section in 2008 - an upstream movement with a single apex, movement along the spawning habitat for 12-24 hours (h), followed by variable downstream movement. Spawning appears to have occurred over or adjacent to coarse substrate at the base of a revetted outside bend. PLS09-007 was recollected within hours of moving downstream on April 26. Examination using minimallyinvasive methods (ultrasound and endoscopy) indicated PLS09-007 had spawned completely. The last few eggs were removed from the oviducts during endoscopic procedures and preserved in formalin. Later examination of the eggs indicated that they had undergone germinal vesicle breakdown and were ready to be fertilized. The probable spawning habitat was intensively mapped (see task 3 ) and DIDSON and sidescan sonar imagery were collected at the spawning location. Aggregations of fish, including sturgeon and paddlefish (Polyodon spathula) were recorded. Extreme high water (discharge greater than $250,000 \mathrm{ft}^{3} / \mathrm{s}$ ) in the days following spawning prevented field crews from attempting to collect eggs, larvae, or other adult sturgeon at the spawning site.

Patterns of movement and behavior of sturgeon implanted in the upstream section were variable as in 2008. PLS09-009, which had a PI of 0.09 showed very little upstream movement before initiating a downstream movement of approximately 6 miles (fig. 5). Field crews recaptured PLS09-009 on May 7, 2009, determined it had not yet spawned, extracted an egg sample, and released the fish at the recapture site. A mean PI value of 0.05 indicated that the eggs were mature and ready to spawn. More than 20 large paddlefish in spawning condition also were captured in drifted trammel nets during recapture attempts. Within hours of release, PLS09-009 was joined in close proximity by three pallid sturgeon males with transmitters (PLS07-020, PLS08-036, PLS09-003) near river mile 660 (fig. 6). On May 9, PLS09-009 and two males subsequently moved downstream to river mile 650. PLS09009 remained at the second downstream location until May 11. Telemetered males were found near the second potential spawning site until May 18. Contact was lost with PLS09009 on May 11 during intensive tracking. It was assumed that PLS09-009's implanted transmitter failed. Therefore, spawning could not be confirmed through recapture. Each of the tagged males present during the aggregation events were implanted in different years; one each in 2007, 2008, and 2009. All transmittered males located in aggregations with the tagged female were recaptured within days of the aggregation events. All were expressing milt and the reproductive condition of the testes was verified using ultrasound and surgical examination of the gonads.

Field crews sampled the upper section aggregation and the probable spawning sites for larval sturgeon using paired 0.5 meter $(\mathrm{m})$ icthyoplantkon nets on the bottom and mid-water column (Simpkins and LaBay, 2007). Probable spawning times and water temperatures at spawning were used to calculate likely hatch times. Larval sturgeon were sampled after the estimated hatch date downstream from each potential spawning site at three equidistant locations along a transect from outside bend to mid-channel. The aggregation site near river mile 660 was sampled for larvae on May 14 and the site near river mile 650 was sampled on May 15 and 16. A total of 163 early Acipensiformes larvae were collected. Of these, 162 were positively identified as paddlefish and one was identified as a Day-0 posthatch Scaphirhynchus sturgeon larvae. Of the 82 samples collected, 58 (70.7 percent) contained paddlefish. The sturgeon larva was submitted for genetic analyses and was determined to be a shovelnose sturgeon (Edward Heist, Southern Illinois University, Carbondale, Illinois, written commun., 2009).

In addition to intensive tracking of reproductive adults, monthly river sweeps were conducted outside of the spawning season to relocate adult sturgeon. During river sweeps, tracking crews attempt to search the length of the Missouri River from Gavins Point Dam, Nebr., to the mouth at St. Louis, Mo., within a 10- to 14-day period. These extensive relocation efforts have been effective at documenting seasonal patterns of movement and may be valuable for identifying critical habitats. More frequent tracking efforts were made in areas where densities of transmittered sturgeon were highest (for example, between Rulo, Nebr., and Decatur, Nebr.). In July, tracking crews searched the Mississippi River for transmittered fish from the mouth of the Missouri River to the confluence with the Ohio River at Cairo, Ill. Two adult pallid sturgeon telemetered and released in the Missouri River were relocated. One was a female that spawned in the Missouri River in 2008, and the other was a female that was captured in the Missouri River for hatchery broodstock in 2008. Longterm tracking efforts have highlighted the connection of the Missouri River with the Mississippi River and also have revealed some level of site fidelity among individual pallid sturgeon between seasons and years. Movement and habitat use may be highly variable with pallid sturgeon capable of moving hundreds of river miles in a season (DeLonay and others, 2007b). However, long-term tracking of individuals has demonstrated a propensity for at least some pallid sturgeon to utilize single bends or small habitat patches for many months at a time (fig. 7). Few telemetry studies have attempted to recapture tagged individuals and, therefore, may assume, perhaps incorrectly, that many of these locations were expelled transmitters or dead fish. Interestingly, a number of adult pallid sturgeon have demonstrated a fair degree of fidelity to localized sections of the river-returning after absences of several months and movements greater than 50 river miles (fig. 7). While a few anecdotal observations may 


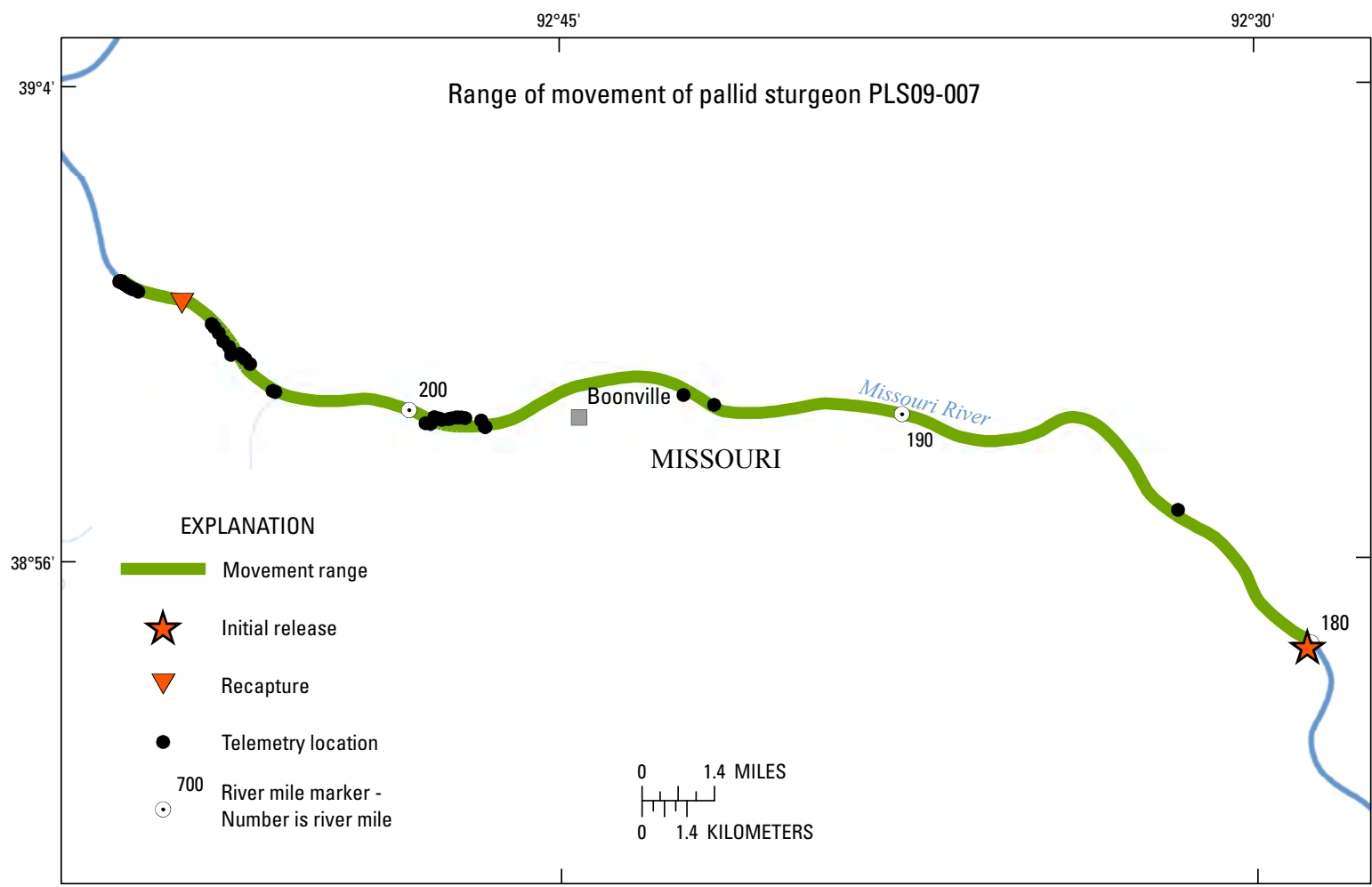

Base from U.S. Geological Survey, digital data, 1999, 1:2,000,000

River miles from U.S. Army Corps of Engineers (1960) Universal Transverse Mercator projection

Zone 15
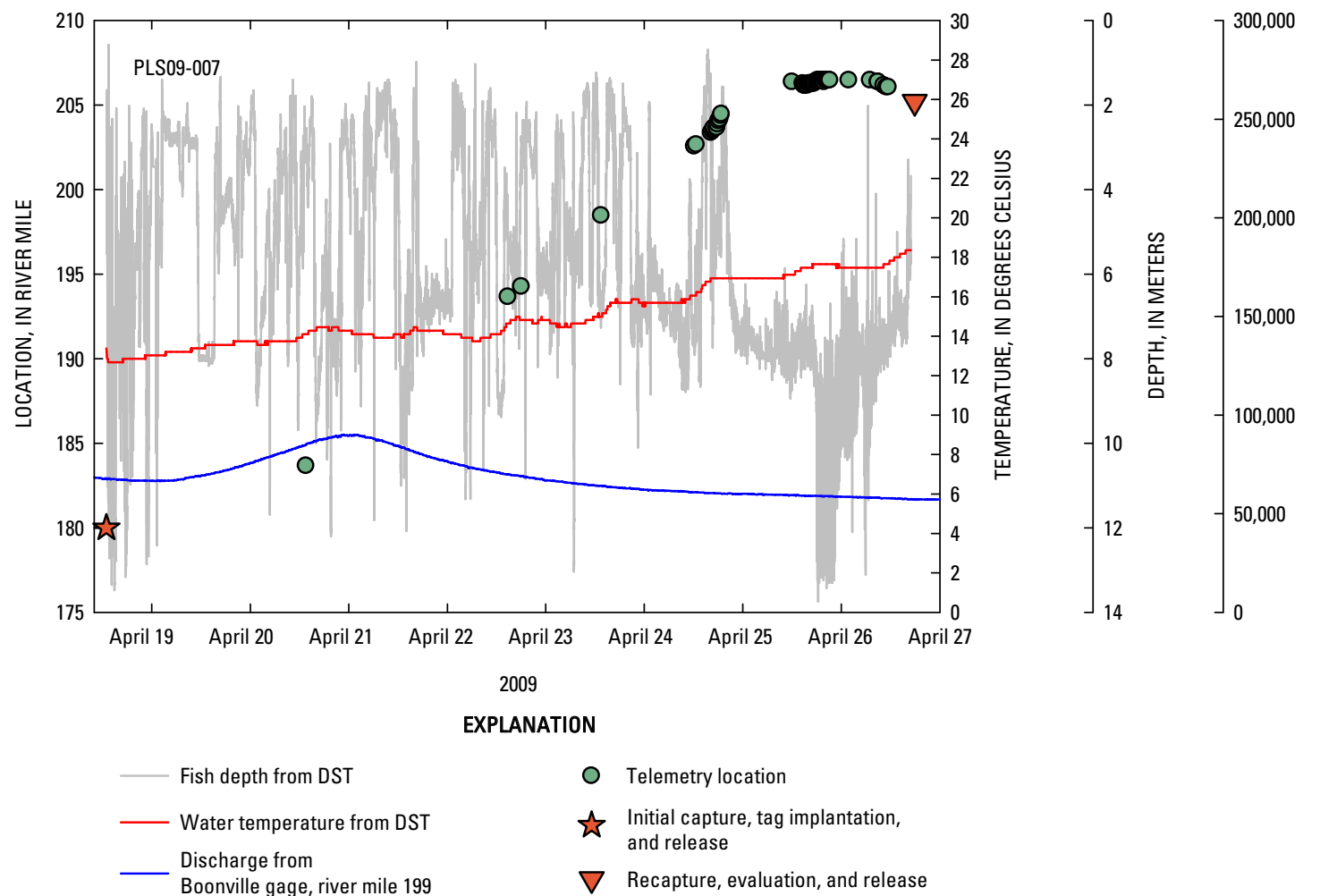

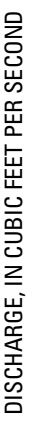

Figure 4. Movement range of pallid sturgeon PLS09-007. Depth and temperature recorded from data storage tags (DST), discharge from the nearest gage, and telemetry locations for implanted gravid pallid sturgeon PLS09-007. Fish were implanted in reproductive condition, later recaptured, and determined to have spawned. 

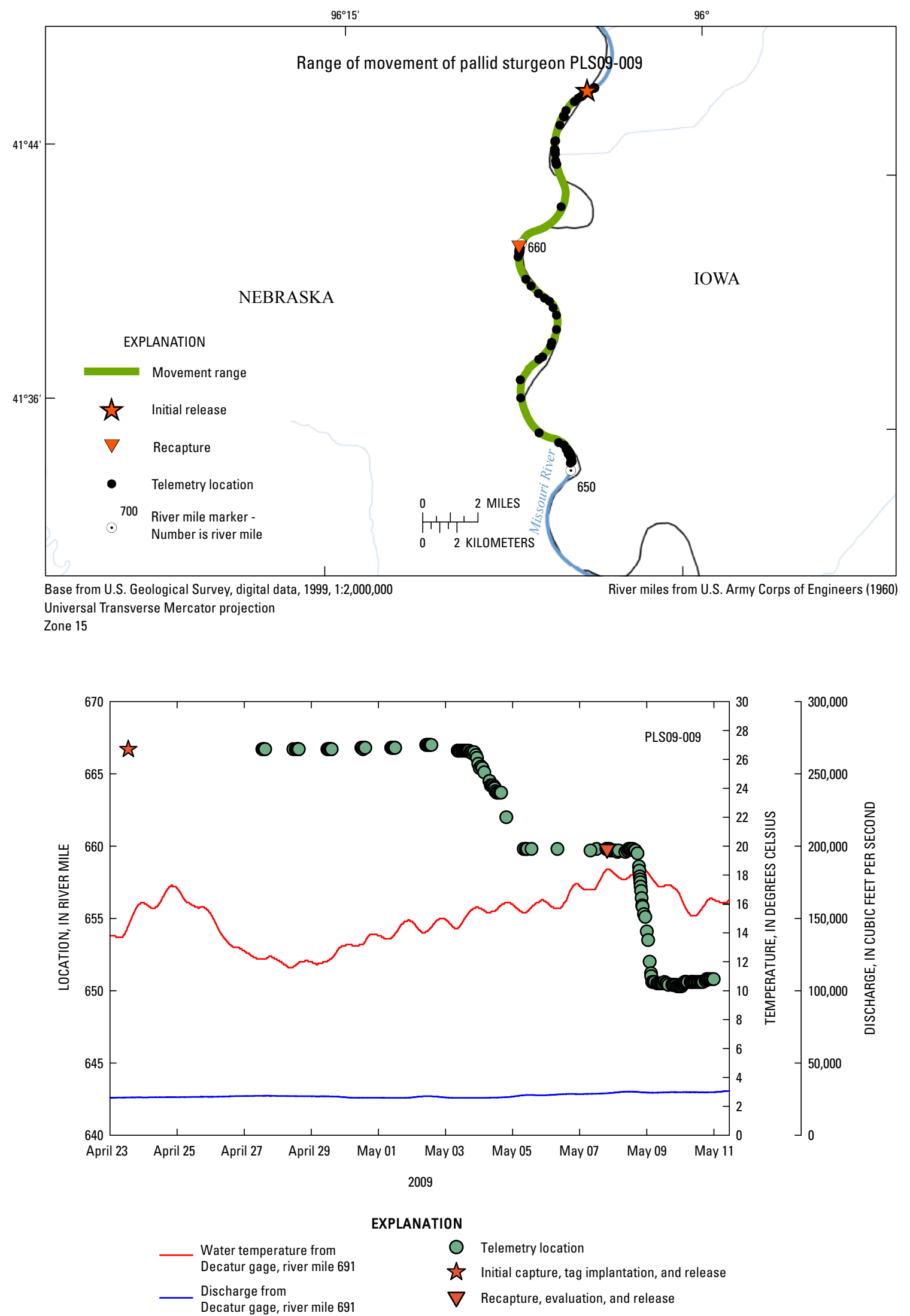

Figure 5. Movement range of pallid sturgeon PLS09-009. Temperature and discharge from the nearest upstream gage and telemetry locations for implanted gravid pallid sturgeon PLS09-009. Fish were implanted in reproductive condition and had not yet spawned upon recapture. It is unknown if this fish spawned in 2009. 

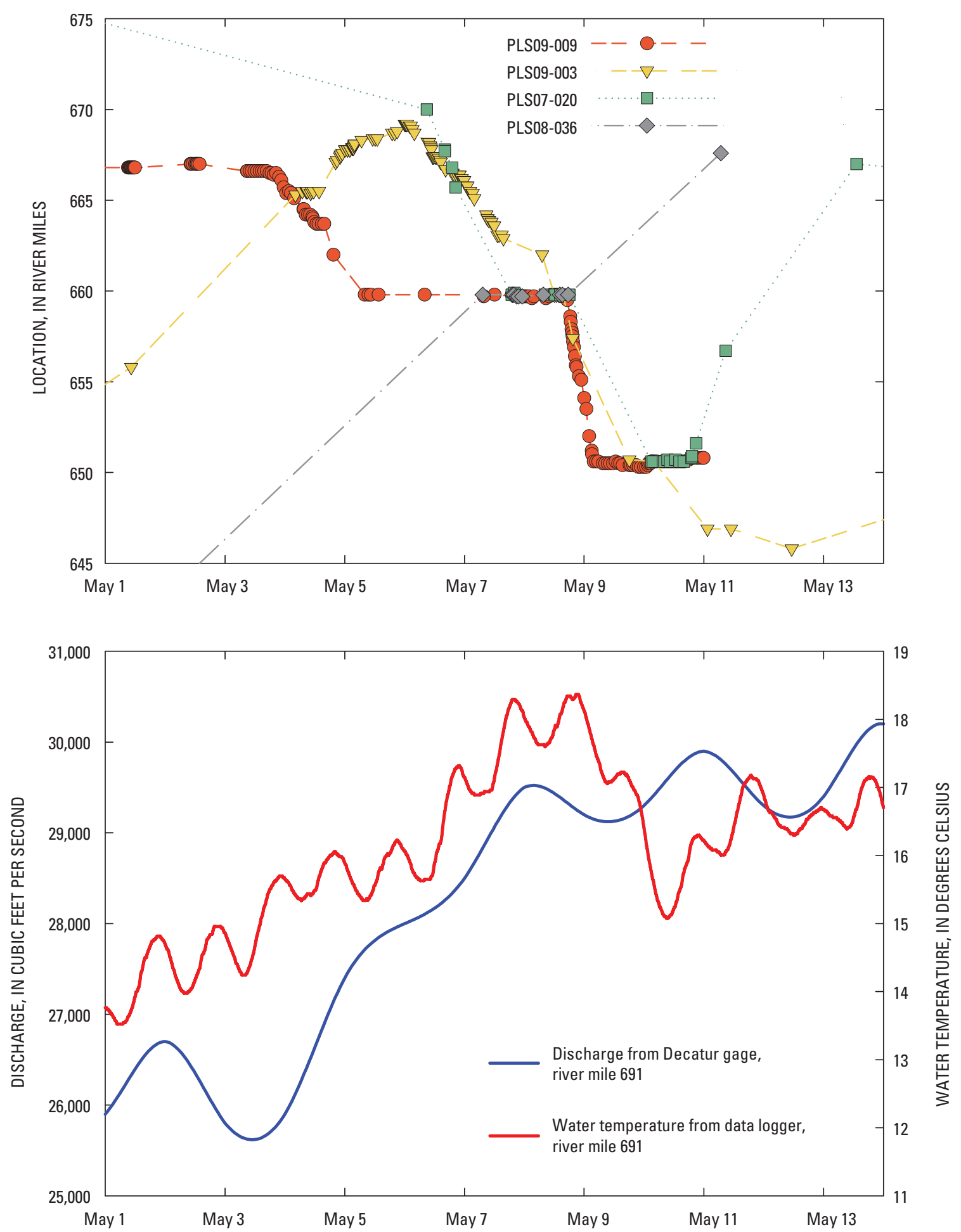

2009

Figure 6. Telemetry locations of gravid female pallid sturgeon PLS09-009 and reproductive male pallid sturgeon PLS09-003, PLS07-020, and PLS08-036 showing probable spawning aggregations. Discharge from the nearest upstream gage at Decatur, Nebr. Temperature recorded from instream datalogger located near the gage at Decatur, Nebr. 

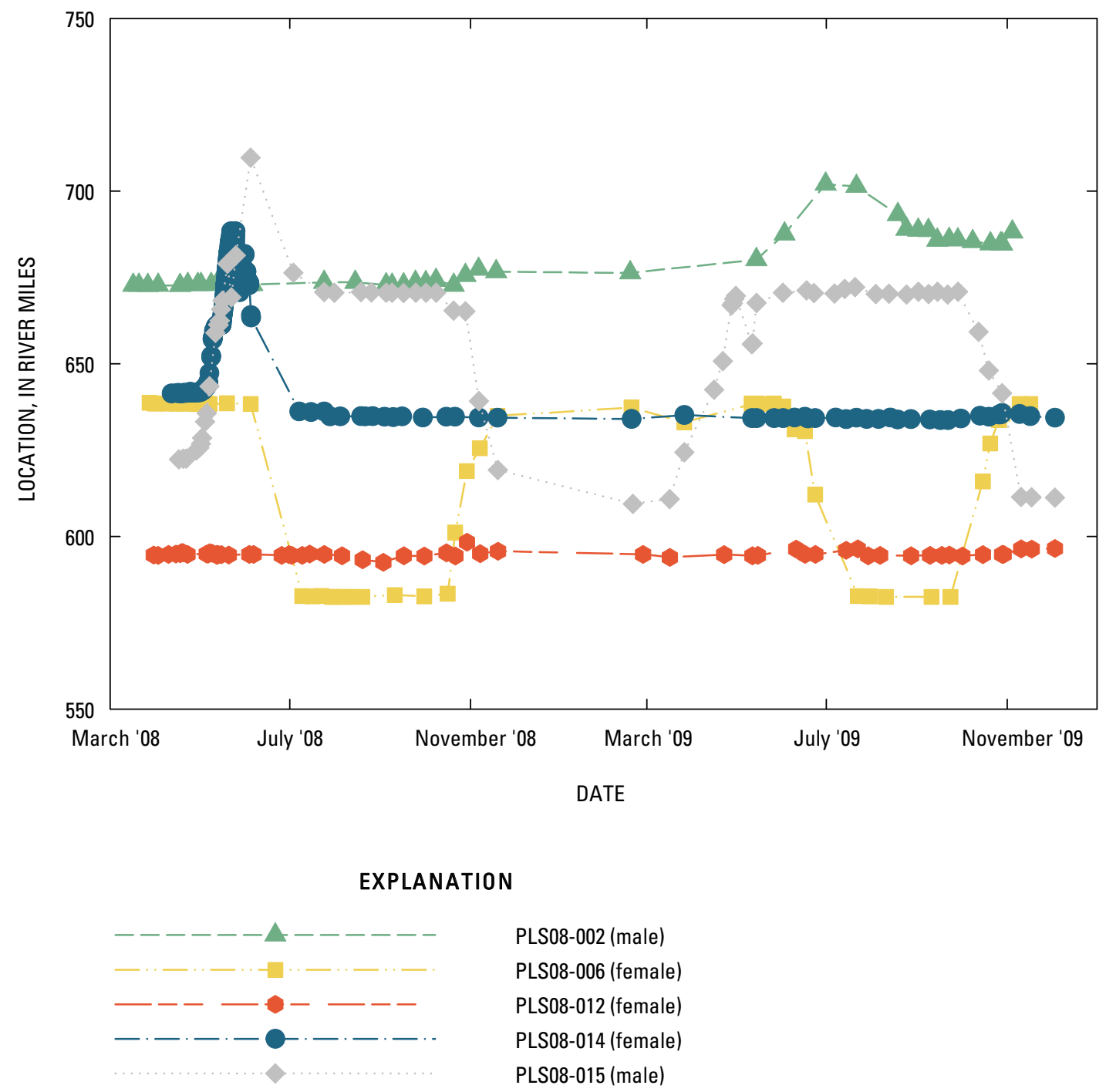

Figure 7. Telemetry locations for implanted pallid sturgeon PLS08-002, PLS08-006, PLS08-012, PLS08-014, and PLS08-015.

document the ability of pallid sturgeon to recognize and return to habitat patches over large spatial scales, repeated patterns of use of specific habitat locations by sturgeon over seasons and years would be highly significant. Further observations are needed to determine the degree to which pallid sturgeon express preference or fidelity for discrete patches of habitat over time.

Field crews began to target telemetered pallid sturgeon for recapture and reimplantion as water temperatures cooled in early September. A total of 15 pallid sturgeon implanted in previous years were recaptured, reassessed, and reimplanted with 2-year transmitters and 2-year programmable DST tags. One reimplanted sturgeon is a female that was intensively tracked and determined to have spawned in 2008. Examination during reimplantion indicates that reproductive condition will occur again in spring 2010. This is the first documentation that pallid sturgeon females in the Lower Missouri River may cycle into reproductive condition in as few as 2 years, a finding that could have important implications for understanding population dynamics. This type of information on reproductive periodicity and spawning site fidelity can only be obtained through repeated recapture and reproductive assessments of telemetered individuals.

Data from 2009 spring sampling were entered into electronic data bases (task 4), and tissue samples and meristic data were transmitted to the USFWS. Data collected on previously tagged shovelnose, pallid, and lake sturgeon (Acipsesnser fulvescens) were provided to the Missouri Department of Conservation (MDC) for inclusion in basinwide data bases and for dissemination to collaborating agencies. A compendium of methods, and all capture, tagging, 
and tracking information collected between 2005 and 2009 will be released in the future.

Presentations of results from this task were presented at a sturgeon symposium on Acipensiformes in North America at the National American Fisheries Society Conference in Nashville, Tenn., and at the International Sturgeon Symposium in Wuhan, China.

\section{Discussion}

Intensive tracking of reproductive adults yielded similar results to those observed in 2008 (DeLonay and others, 2009). The gravid female pallid sturgeon (PLS09-007) implanted in the lower study section showed a characteristic upstream movement, spawning quickly at the apex of its migratory path. Spawning occurred in deep (greater than $3 \mathrm{~m}$ ), swift water (greater than $1 \mathrm{~m} / \mathrm{s}$ ) over or adjacent to coarse substrate along the base of a revetted outside bend. The upstream gravid female pallid sturgeon (PLS09-009) did not migrate or show any significant upstream movement. Unfortunately, recapture of PLS09-009 was not successful to confirm spawning success or failure. However, based upon aggregations of adults in the upstream study section, probable spawning locations were mid-channel to outside revetted bend. While numbers of probable documented spawning sites are still low and are based on movement of intensively tracked female pallid sturgeon and aggregations of reproductive adults, the characteristic patterns of movement and general habitat features selected for spawning by gravid female pallid sturgeon are consistent from year to year. A pattern of disrupted or impaired migration in the upper study section also was repeated in 2008. DIDSON observations of adult paddlefish at the downstream spawning locations and the presence of large numbers of spawning adults and early paddlefish protolarva at the upper spawning locations suggest that both species may be selecting and using similar spawning habitat in the mainstem Missouri River. Depending on the sequence of species that use the same spawning location and preferred spawning temperatures, the presence of spawning paddlefish or other rheophilic species may act as a social indicator of likely sturgeon spawning locations and, in some instances, may be a cue to migrating sturgeon, indicating the presence of suitable spawning habitat.

Successful tracking of reproductive adult sturgeon continues to be complicated by rarity of gravid female sturgeon. Capture efforts in 2009 did not yield reproductive females until late April after the individual females were ready to spawn. Despite imminent physiological readiness to spawn, females tolerated implantation and showed they can spawn and release their eggs effectively. It is somewhat significant that the female in the lower study section (PLS09-007) moved upstream for 7 days after implantation and released viable eggs. This suggests that there may be some flexibility or latitude of females to wait for or move to more favorable spawning conditions during a window of physiological readiness.
The aggregation of reproductive male and female pallid sturgeon observed during intensive tracking in the upstream study section is the first documented aggregation of telemetry tagged pallid sturgeon in the Lower Missouri River. Tracking data from this study indicate that even though the species is extremely rare, reproductive adults can find one another at the appropriate time. Data also indicate that males using multiple migratory strategies (for example, single and multiple apices, upstream and downstream movement patterns) are effective at finding mates (DeLonay and others, 2009). The presence of reproductive males implanted in three different years, at disparate locations, indicates that the aggregation event was not an artifact of clustered sampling and implantation strategies, random movement, or predetermined habitat affinities.

Capture and tracking data clearly show that wild and hatchery-origin pallid sturgeon are surviving, growing, reaching reproductive maturity and spawning in the Lower Missouri River. Spring capture data collected from 200709 indicate that hatchery individuals will soon comprise the predominant portion of the pallid sturgeon spawning population in the Lower Missouri River. While spawning does occur, it remains unclear whether it is successful or whether it is occurring at the most appropriate time, place, or under conditions that would result in significant survival of progeny. Managers need to know whether spawning by pallid sturgeon is sufficient, and how it can be enhanced through specific modification or manipulation of factors under management control. While the early benefits of artificial propagation are readily apparent, the long-term effects of propagation, habitat manipulation and flow modification on population sustainability and ultimate recovery will take years to assess.

\section{Summary and Conclusions}

Results of studies conducted under task 1 during 2009 added substantial new information on pallid sturgeon movement, habitat use, and behavior. This information has resulted in compelling hypotheses that have direct management and recovery application (DeLonay and others, 2009; Reuter and others, 2009). The study has been limited by the availability of adult pallid sturgeon, especially reproductive adults. Verification and validation of spawning and spawning success will provide information to assess whether spawning, fertilization, egg survival, and hatch are limiting in reproduction. Gaps in habitat use information exist for juvenile lifestages, seasons outside of the spawning areas, and in parts of the river not included within the study sections. Connectivity to the Mississippi River and the relative importance of major tributaries to the mainstem Missouri River are for the most part unexplored. These gaps limit the ability to discern the long-term patterns in distribution and habitat use and give little insight into critical genetic and metapopulation dynamics. Closing these gaps is critical to understanding habitat quality and the sufficiency of habitat to provide necessary ecological benefits to the species. 
Task 2. Reproductive Physiology to Support Assessment of the Importance of Spring Flows, Temperature, and Photoperiod to Successful Pallid Sturgeon Spawning in the Missouri River

\section{Background}

Task 2 provides the supporting data and analyses essential to evaluate the biological response of pallid sturgeon to environmental conditions including natural spring pulses and pulsed-flow releases in the Missouri River. This task also continues to develop tools and acquire multiyear geographic and condition-specific data to answer questions about when, where, and what environmental cues are necessary for pallid sturgeon to spawn.

A fundamental aspect of the life-history strategy of an individual is the temporal pattern of reproduction. An important contributor to fish reproductive success is synchronization of seasonal environmental conditions with the reproductive cycle. Photoperiod, temperature, and characteristics of the flow regime are the primary factors that cue the reproductive physiology of most fishes. Physiological and morphological measurements allow the scientist to evaluate the response of the sturgeon to environmental conditions. Responses may be general, such as stress, or specifically indicate how close a sturgeon is to ovulation.

Reproductive assessment prior to a telemetry study and again at recapture provides information on the reproductive readiness of the fish and, subsequently, whether spawning was successful or resulted in resorbtion of oocytes. Moreover, assessment of the physiological status of captured wild sturgeon allows for an understanding of the environmental factors necessary for successful completion of the reproductive cycle. Determining physiological readiness to spawn allows the prediction of approximately 'when' an individual sturgeon should spawn. This information can be combined with tracking and capture information (location, speed, pattern, and direction of movement) to predict 'where' the sturgeon spawn. Physiological measurements on fish captured over time in a specific location can reveal whether a group of fish are synchronized and, therefore, likely responding to the same environmental cues, or if they are aggregating at a particular site to spawn.

\section{Scope and Objectives}

The objectives of task 2 are to (1) use physiological measurements to provide sex identification, assess reproductive readiness, assess stress of capture, and evaluate success of spawning for tracked sturgeon; (2) evaluate shovelnose and pallid sturgeon prespawning and postspawning reproductive condition coincident with local environmental conditions; (3) develop tools and assays to measure and analyze specific shovelnose and pallid sturgeon reproductive hormones important in cueing migration, gamete maturation, and release; and (4) use laboratory mesocosm studies and semi-controlled field studies to develop novel and advanced approaches to identify when, where, and under what conditions pallid sturgeon spawn.

\section{Methods}

Field crews and other agencies involved in Missouri River sturgeon research were supplied with tissue collection materials in support of task 1. Blood plasma was analyzed for sex hormones at implantation of transmitters and upon recapture for readiness to spawn and stress. In an effort to reduce costs, plasma was not tested for cortisol and the progesterone assay was not performed as in previous years. Spawning success was evaluated based on visual inspection of gonads and blood reproductive hormones.

Research was conducted to better define the environmental factors (including natural spring pulses and pulsed-flow releases) necessary for completion of the reproductive cycle and successful spawning in the Lower Missouri River. The approach was to assess the reproductive condition of the sturgeon prior to spawning migration, during the migration, as soon after spawning as possible, and to relate the readiness to spawn and success in spawning to discharge characteristics, temperature, and day length. Data were collected from fish used in telemetry task 1 and opportunistically by others who collected sturgeon in the Missouri River or its tributaries. Unlike in past years, fish were not collected specifically for this task. Temperature and flow data were obtained from river gages, deployed data loggers, and data collected by field crews.

The third objective extends ongoing work conducted at USGS to develop tools and assays to measure gonadotropin II (GtH II) and maturation-inducing hormone (MIH). Over the last few years, biochemical and molecular approaches were used to develop a GtH II antibody or probe. Chromatographic methods are being used to identify the composition of the $\mathrm{MIH}$. Once identified, antibodies to GtH II will be used to develop an enzyme-linked immunosorbent assay (ELISA) to measure GtH II and a radio immune assay (RIA) will be developed to measure MIH.

Reproductive shovelnose sturgeon were collected from the Missouri River within the lower study section near Boonville, Missouri (river mile 190.7), and transported to CERC. The large size of sturgeon makes it difficult to maintain and study natural behavioral patterns under simulated riverine conditions in the laboratory. The wildcaught shovelnose sturgeon were induced to spawn using hormonal injections and released to the outdoor continuouslooped earthen raceway constructed at CERC. This flowing 
'living-stream' mesocosm provides an opportunity to observe Scaphirhynchus in the spawning act using remote sensing equipment. The intention is to use this approach to 'calibrate' the remote sensing images (DIDSON and side-scan sonar) collected in the field in order to provide better interpretation of remotely sensed field data.

\section{Results}

Data were collected for 3 female and 10 male pallid sturgeon tracked in 2009. Additionally, data were collected on 59 pallid sturgeon mostly of undetermined sex that were not tracked. Two of the tracked females were gravid with black eggs and the third was nonreproductive. Gravid female pallid sturgeon PLS09-007 (acoustic code 54500, PIT 472E35150C) was instrumented April 18 with a PI of 0.06 and was recaptured April 26 after upstream movement and apparent spawning behavior. Upon collection, it was noted that she had spawned completely. The few eggs collected from the oviduct were fresh and partially through germinal vesicle breakdown indicating that spawning had taken place only hours before recapture. Testosterone (T) and 11-ketotestosterone (KT) levels measured at recapture were still elevated also indicating that spawning had occurred very recently (within hours) (fig. 8A). Gravid female pallid sturgeon PLS09-009 (acoustic code 54604, PIT 48685D0E30) was instrumented April 22 with a PI of 0.9 and recaptured May 7. Reproductive assessment on May 7 indicated that PLS09-009 had not yet spawned and it was released. Contact with this female was lost on May 11 and, subsequently, it was not recaptured to evaluate spawning success. All hormone levels at recapture were lower than expected for a gravid female at this time of year and at this reproductive stage (fig. 8B). Although the PI value declined between the time of initial implantation and recapture 2 weeks later, PLS09-009 did not initiate an upstream movement typical of spawning female sturgeon. The PI was 0.05 , indicating spawning was closer than when initially captured approximately 2 weeks earlier. The nonreproductive female PLS09-008 (acoustic code 1046, PIT 471E191E44) was believed to have spawned in 2008 based on visual inspection of ovary and when captured April 22 had a hormone profile consistent with a Stage II female (fig. 8C).

Five reproductive males had similar hormone profiles consistent with Stage V males (fig. 9A). A sixth male, PLS09-005 (acoustic 1050, PIT 4704237D39), characterized at capture on April 1 as having 'some large lobes', had very low T and KT levels more typical of a spent or Stage II male (fig. 9B). The instrumented nonreproductive males fell into two groups. Males PLS08-017 (acoustic code 576 and 1107, PIT 4349020B20), and PLS09-011(acoustic code 1108, PIT 434A00324C) had low T and KT levels characteristic of Stage II males and were described as such upon capture on September 11 (fig. 9C). Males PLS07-019 (acoustic code 557 and 1110, PIT 412C6A535B) captured September 9 and
PLS09-010 (acoustic code 1109, PIT 4716133136) captured September 8, had elevated T and KT levels normal for Stages III-V, but given reported associated fat was probably Stage IV (fig. 9D).

The fish that were not tracked were caught between March 6 and May 12 and ranged in length from 354 to 1,084 $\mathrm{mm}$. Hormones and vitellogenin were measured in these fish to gather background data on circulating levels of hormones in nonreproductive and juvenile pallid sturgeon and to determine at what size (age) Missouri River pallid sturgeon enter the reproductive cycle. Analyses on these fish are in progress.

Insufficient numbers of reproductive pallid sturgeon were collected to evaluate 2009 physiological responses relative to environmental cues of flow, photoperiod, and temperature. However, 2009 data plotted with results from previous years show a general trend of decreasing $\mathrm{T}$ and $\mathrm{KT}$ for pallid sturgeon females around the middle of April to the beginning of May when spawning is believed to occur (fig. 10A,B). The trend for males is similar (fig. 10C,D). Gravid female PLS09-007 (acoustic code 54500, PIT 472E35150C) in the lower study section spawned during a period when discharge increased from $68,200 \mathrm{ft}^{3} / \mathrm{s}$ to $83,900 \mathrm{ft}^{3} / \mathrm{s}$ then decreased to $57,800 \mathrm{ft}^{3} / \mathrm{s}$, and temperature increased from 12.6 to $17.6^{\circ} \mathrm{C}$ (fig. 10E).

Despite successful genetic sequencing of pallid sturgeon GtH II hormone and inclusion in a plasmid vector, production of the GtH II protein was very slow because of low protein yield under conditions in CERC laboratories. Therefore, the decision was made to provide the sequence information to a commercial producer to obtain the requested 20 milligrams (mg) of protein necessary for antibody production. After several months, and at no cost, the commercial laboratory was unable to obtain sufficient material for antibody production and abandoned the project. Therefore, it was decided to use another approach to obtain the needed antibody. A colleague in Russia donated sufficient sturgeon GtH II protein to submit to the commercial producer of the GtH II antibody. The Abraxis laboratory has successfully made the sturgeon antibody and, although, it is not specific to pallid sturgeon, the $\mathrm{GtH}$ II protein is similar across fish species and is expected to recognize and bind pallid sturgeon GtH II antigen. Final phases of development of the ELISA for measuring GtH II are currently underway.

Previously, the putative Scaphirhynchus MIH was identified. However, before measurement of MIH in sturgeon can begin confidently, the MIH in several individuals must be confirmed. Therefore, again this year, MIH was purified from shovelnose sturgeon. Because of equipment malfunctions, the purification required several months longer than expected. As such, the necessary experiments could not be completed within the narrow window within which sturgeon are at the required reproductive stage. These experiments will be attempted during 2010. 

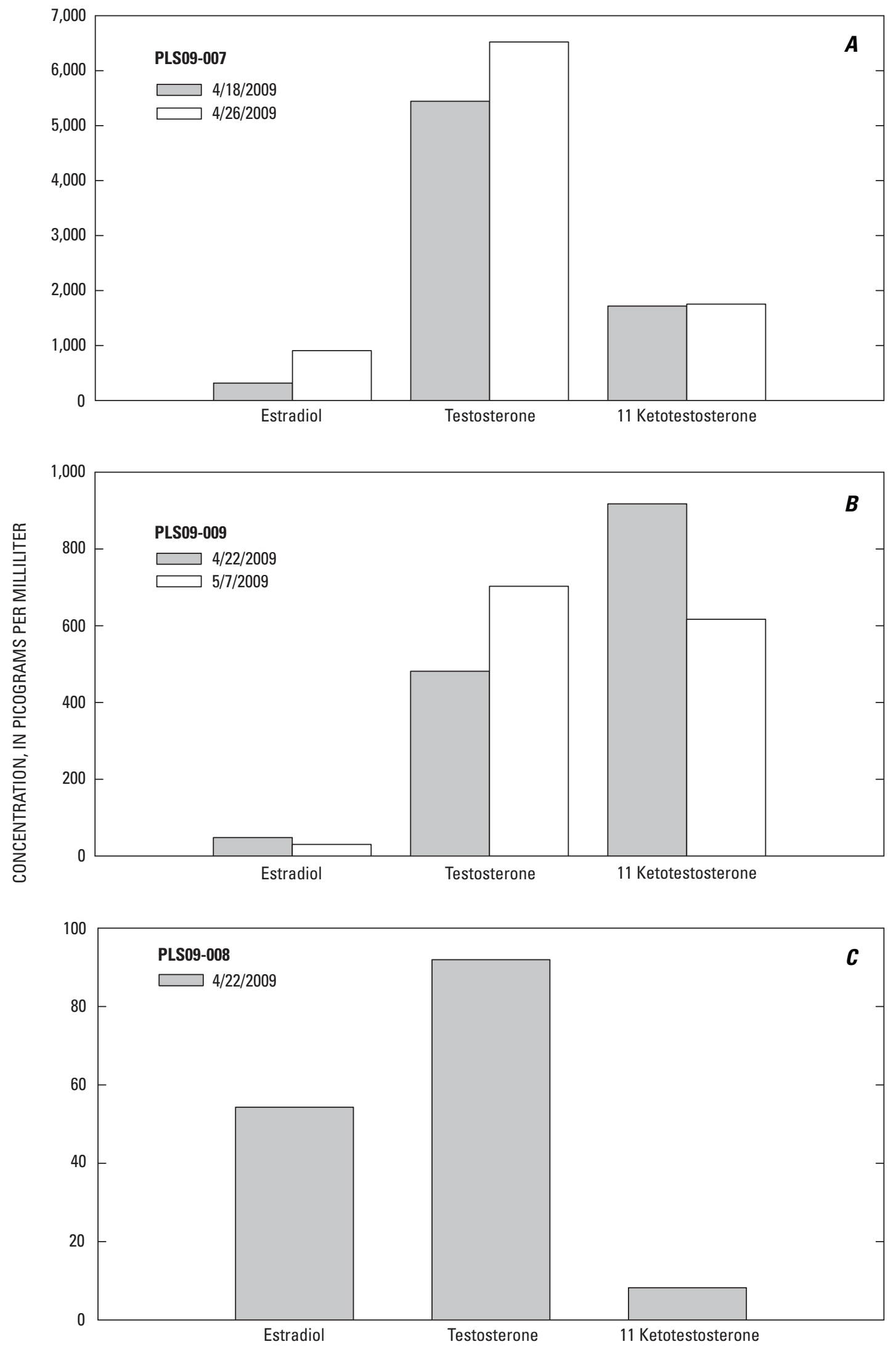

Figure 8. Female pallid sturgeon tracked in 2009 in the Missouri River. A) PLS09-007 is a confirmed spawner. B) It is unknown if PLS09-009 spawned. C) PLS09-008 was a nonreproductive female. 

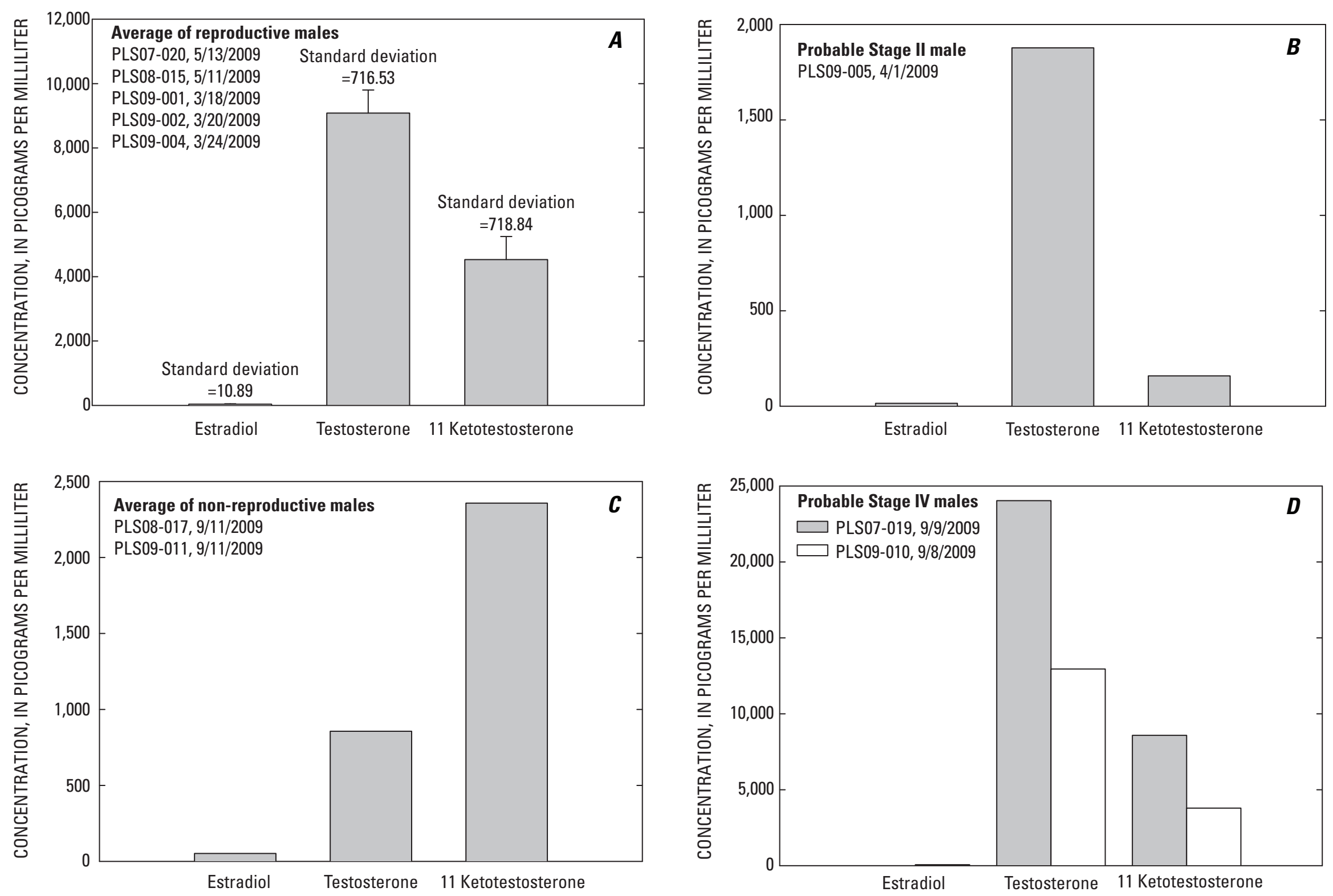

Figure 9. Male pallid sturgeon tracked in 2009 in the Missouri River. (A) Reproductive males. (B) Probable Stage II male. (C) Nonreproductive males. (D) Probable Stage IV males caught in September. 
$\boldsymbol{A}$

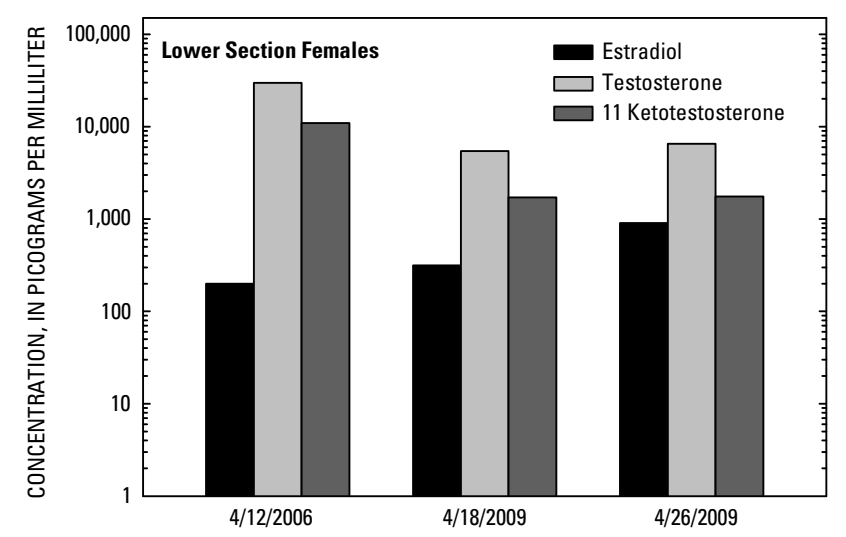

C

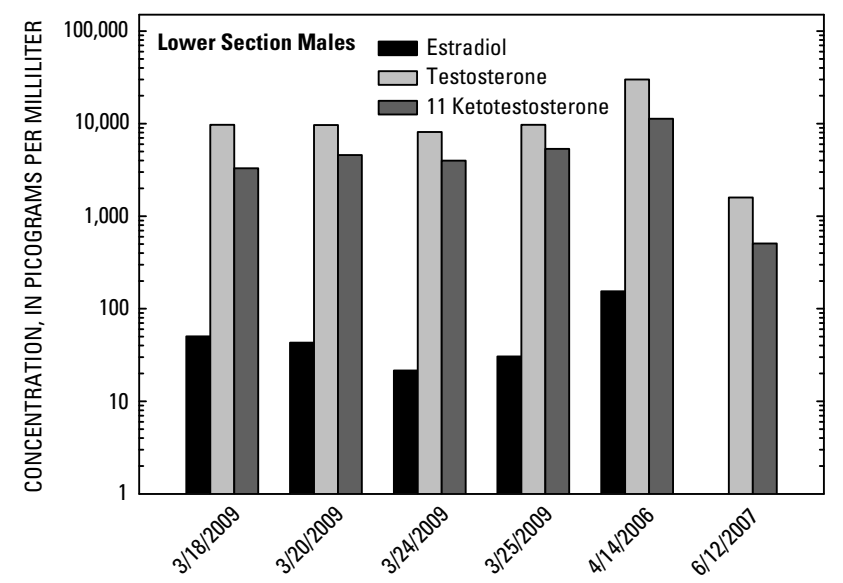

$\boldsymbol{E}$

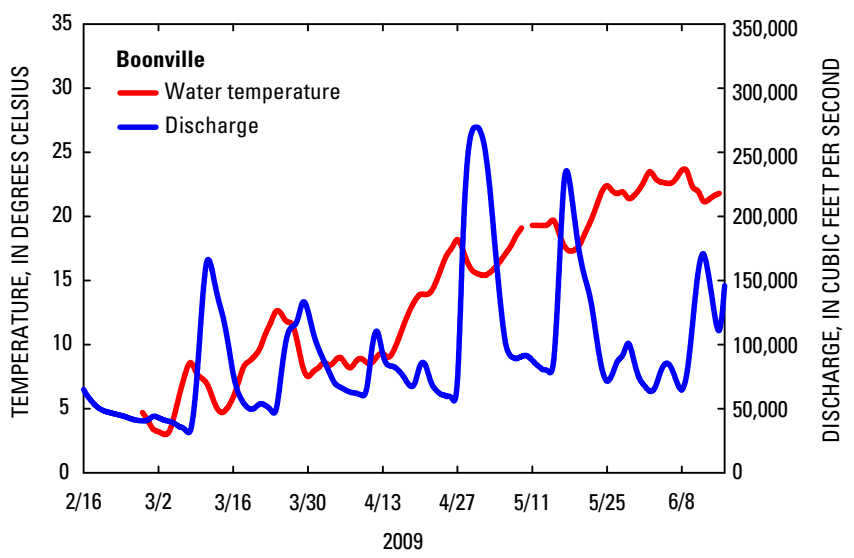

$\boldsymbol{B}$

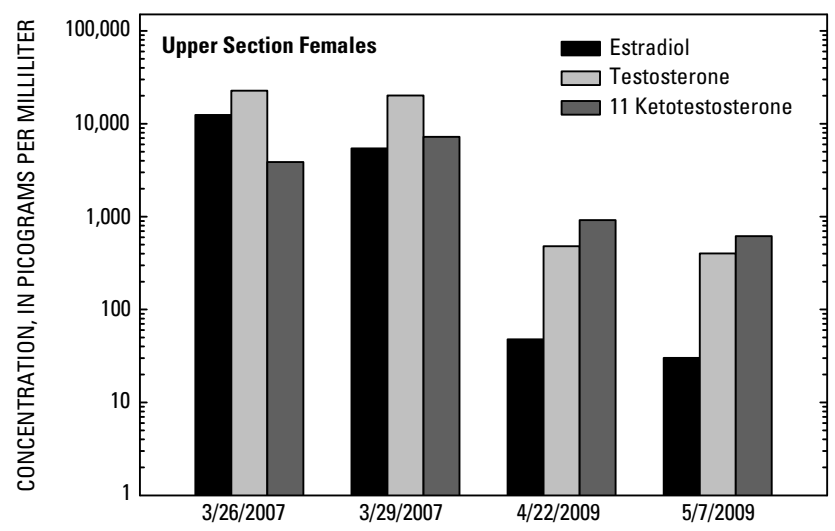

D

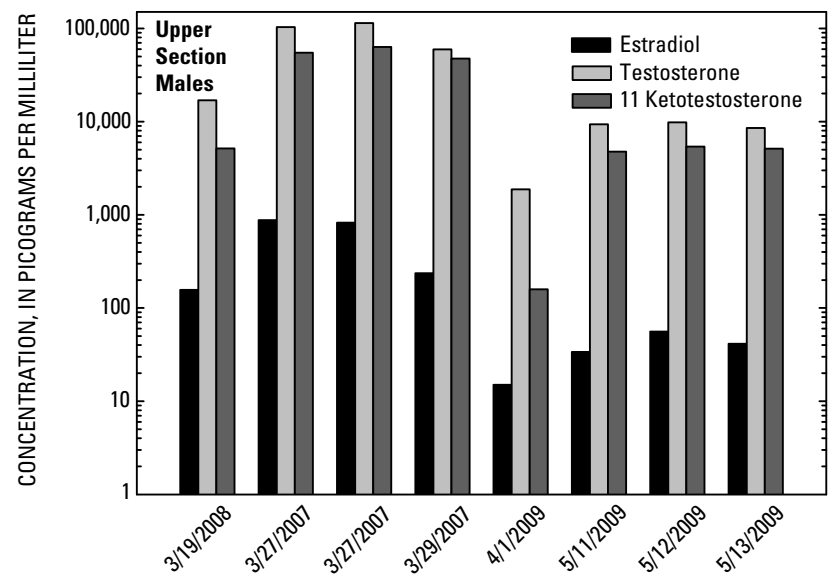

$\boldsymbol{F}$

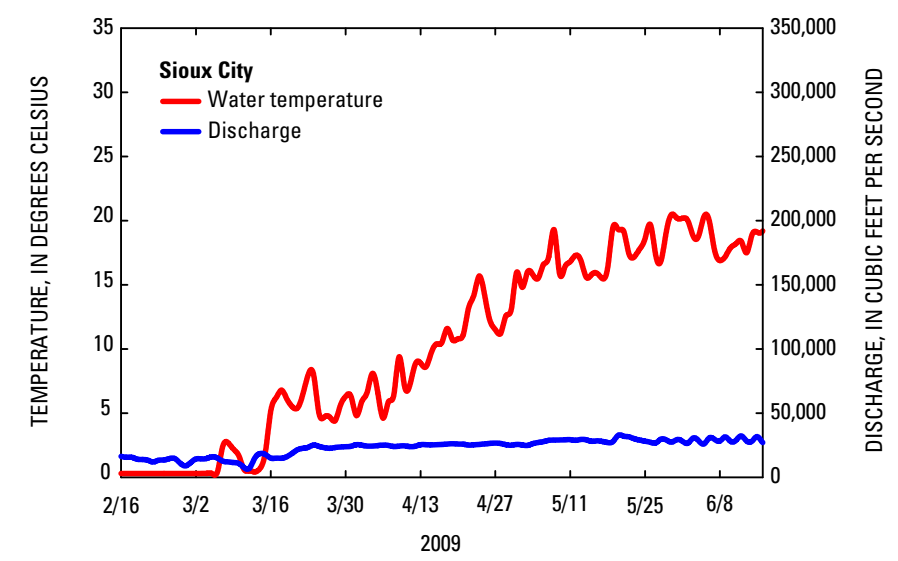

Figure 10. Hormone levels on day of capture for reproductive pallid sturgeon captured in 2006-09 in two sections of the Missouri River, and discharge and temperature profiles in these river sections. $A, B)$ Female pallid sturgeon. $C, D$ ) Male pallid sturgeon. $E$ ) Boonville, Missouri, water temperature and discharge during 2009. F Sioux City, lowa, water temperature and discharge during 2009. 
Reproductive shovelnose sturgeon were hormonally induced using methods similar to those described in the hatchery literature (Conte and others, 1988). Induced sturgeon were stocked into the CERC pond and followed with a DIDSON acoustic camera in order to capture images of spawning sturgeon. This experiment did not have the anticipated results. Sturgeon did not spawn, possibly because it was after the peak spawning period when the experiment was conducted. Nevertheless, this initial experiment provided valuable information on how to mount, deploy, optimize angles, and gain settings of the DIDSON to improve detection of the benthically-oriented sturgeon. The experiment will be attempted again during spawning season 2010.

\section{Discussion}

Two reproductively ready pallid sturgeon females were implanted with transmitters and tracked during the spring 2009 spawning season. PLS09-007 (acoustic code 54500, PIT 472E35150C) moved upstream, exhibited spawning behavior, was recaptured, and confirmed to have spawned. PLS09009 (acoustic code 54604, PIT 48685D0E30) did not move upstream and when recaptured after downstream movement was determined to have not yet spawned. PLS09-007 was captured at river mile 180, whereas PLS09-009 was captured at river mile 666.7. The stress from surgery alone was likely not the reason for the apparent failure of PLS09-009 to migrate upstream and spawn but may have been a contributing factor. Both females had PIs indicative of spawning ready sturgeon (0.06 and 0.05) and normally low estradiol (E2) levels. However, PLS09-009, which had not spawned at recapture on May 7, had T and KT levels that were abnormally low; 2 to 10 times lower than PLS09-007 that moved upstream and spawned near river mile 206 on April 25-26. Cortisol, a stress hormone, was not measured, therefore, stress levels could not be compared between the two females. Undue stress from handling, temperature, disease, and other factors can cause hormone levels to decline rapidly.

Additional comparative examination of reproductive and stress hormones may provide insight into why some gravid female sturgeon migrate upstream and appear to spawn, and others do not. Sample sizes at this time are limited and why the upper section female did not move upstream to spawn cannot be explained. Similarly, nonreproductive male PLS09-005 (acoustic code 1050, PIT 4704237D39) caught in the upper study section also had low $\mathrm{T}$ and KT levels and at capture there was uncertainty about its reproductive readiness. It, too, may have experienced extreme stress causing the $\mathrm{T}$ and KT levels to decrease. All plasma samples have been archived and analysis for GtH II and $\mathrm{MIH}$ in coming years will provide more accurate information about readiness to spawn relative to environmental conditions.

\section{Summary and Conclusions}

Most sturgeon, pallid sturgeon included, have multiyear reproductive cycles. Environmental conditions, months prior to spawning, likely influence spawning outcome. Thus far, data have not been collected from sufficient numbers of pallid sturgeon to fully characterize seasonal and cyclical hormonal patterns. This lack of information hinders interpretation of effects of environmental conditions on reproduction and spawning. Because pallid sturgeon are rare and needed for propagation and research, it will take several years to have sufficient numbers of pallid sturgeon to acquire the necessary data. Recognizing that only two gravid females were observed in 2009 , the results are consistent with previous years. Not all gravid pallid sturgeon females are moving or migrating to spawn. The reason for lowered reproductive hormone levels, the lack of upstream migration, and the interrelation between physiological development and spawning success are not understood. Many more physiological biomarkers of general health, stress, and reproduction are available and could be employed to provide a better understanding of the fish's response to its environment. Pallid sturgeon held under controlled laboratory conditions could also be studied to better understand their response to environmental variables (photoperiod, temperature, and flow-regime characteristics).

\section{Task 3. Quantify Pallid Sturgeon Migration and Spawning Habitat}

\section{Background}

Habitat assessments quantify habitat used by pallid sturgeon as well as habitat that is available but not used in order to understand habitat selection. By coordinating with studies of reproductive movements and physiology, patterns of habitat selection can indicate whether specific habitats are limiting in the reproduction and survival of pallid sturgeon. Because of the fundamental role of spawning in population dynamics (Quist and others, 2004; Bajer and Wildhaber, 2007; Wildhaber and others, 2007), definition and quantification of spawning habitat was emphasized in 2009 and previous years. Recognizing that previous information supports the idea that spawning habitat itself may not be limiting for pallid sturgeon on the Lower Missouri River, assessments were conducted of habitats used by upstream migrating reproductive sturgeon and larval drift. 


\section{Scope and Objectives}

The main project objective for task 3 was to map migration and spawning habitats in order to replicate assessments conducted in 2008 and to complement previously published habitat information (Reuter and others, 2008; Elliott and others, 2009; Jacobson and others, 2009; Reuter and others, 2009). For these assessments, an enhanced, highresolution habitat mapping protocol was deployed as described below around fish locations identified by telemetry crews. Three of the habitat reaches were identified as probable spawning locations and include high-frequency fish locations. Also, habitats were mapped that are associated with upstreammigrating reproductive pallid sturgeon.

\section{Methods}

Methods replicated those used in 2008; detailed documentation of methods are on file at USGS. Fish locations were selected based on their representation of migratory or spawning behavior. The R/V Brush hydroacoustic survey boat was deployed to a fish location within 24 hours and within 10 percent of the discharge that existed when the fish were located. A temporary benchmark was set up on shore to provide base-station corrections for real-time kinematic (RTK) positioning. The $\mathrm{R} / \mathrm{V}$ Brush is equipped with a dual-receiver global positioning system (GPS) and motion-sensing system, a multibeam echosounder for detailed mapping of the riverbed, and an acoustic Doppler current profiler (ADCP) for mapping current-velocity fields.

The multibeam system is a RESON SeaBat ${ }^{\circledR} 7125$ (RESON, Inc., Slangerup, Denmark) operating at 455 kilohertz $(\mathrm{kHz})$. The transducer and receiver arrays are mounted on the front of the survey vessel on a tilt-up mount. The multibeam system collects data from 512 beams at 0.25 degree spacing and is capable of mapping depths of approximately $1-200 \mathrm{~m}$. The geometry allows a $128^{\circ}$ swath covering approximately four times the water depth.

Positioning and motion sensing data were acquired using an Applanix POS-MV Wavemaster ${ }^{\circledR}$ system with dual GPS receivers and an inertial momentum unit. Using a base station to broadcast RTK corrections from a known benchmark, positioning of the POS-MV was approximately $+/-0.02 \mathrm{~m}$ in the horizontal. The unit provides corrections of vessel heading, pitch, roll, and heave that are acquired and processed by acquisition software.

The multibeam system and boat mount were calibrated with a "patch" test that corrects for internal geometry of the boat, transducer/receiver, and GPS receiver. Patch test results were used to update geometry files used by the data acquisition software. In addition, a sound-velocity profile was collected to assess stratification of sound-velocity with depth. HYPACK/HYSWEEP ${ }^{\circledR}$ software (Hypack, Inc., Middletown, Conn.) was used to acquire, compile, correct, and edit GPS and multibeam data. Hypack and RESON provide real-time quality-control displays that are monitored to ensure quality data are collected.

Longitudinal survey lines were laid out in Hypack at a distance to assure at least 50 percent overlap in multibeam coverage. The lines were parallel to the flow of the river and centered over the chosen fish location. A helm display showed the boat pilot the boat position and the quality and extent of incoming data.

Multibeam files were edited in the office to remove erroneous data. These data were subsequently exported from the Hypack environment and imported into ArcMap (ESRI, Redlands, Calif.) where the data were gridded for analysis and display.

Current velocity fields were mapped using a $1200 \mathrm{kHz}$ acoustic Doppler current profiler (Teledyne RD Instruments, Poway, Calif.). ADCP data were logged simultaneously with GPS data on a laptop computer running WinRiver ${ }^{\circledR}$ (version 10.06, Teledyne RD Instruments, Poway, California). Magnetic variation was set for each reach mapped by using GeoMagix ${ }^{\circledR}$ software (Interpex, Ltd., Golden, Colorado). Mapping crews performed the "Method 3" compass calibration procedure at each site by rotating the boat in a tight circle (RD Instruments, 2003). This procedure corrects for one-cycle errors. The procedure was repeated until the total error reading was less than 1 degree. Configuration settings for ADCP data collection included a bin (vertical cell) size of 25 centimeters $(\mathrm{cm})$ and a blanking distance of $50 \mathrm{~cm}$ below the transducer. ADCP data were collected using water mode 1 with six water pings and bottom mode 5 with one bottom ping.

Velocity data were edited in the office and exported from WinRiver into generic text files. These data were subsequently imported into ArcMap for further processing and gridding.

\section{Results}

Eleven reaches were mapped as part of this year's (2009) effort (table 3). Five mapped reaches included fish located during upstream migration; three migration maps were of males (figs. 11-19), two were of females (figs. 20-25). Three reaches were probable spawning reaches (figs. 26-34). PLS09-007 was mapped at the downstream spawning site at river mile 206.4, was captured 24 hours after mapping, and was shown to have spawned completely (figs. 4, 26-28). Multiple fish were mapped at each of the upstream spawning sites and behavior was complex (figs. 5, 6, 29-34). PLS09009 was recaptured on May 7 after a significant downstream movement and was found to have not yet spawned; it was not confirmed if spawning occurred at either of the mapped locations (river mile 659.7 and 650.6). Two map sites were selected to replicate at high discharge for comparison with earlier maps at lower discharges in order to assess varying bedform conditions (figs. 20-25 and 35-40). 
Table 3. Dates and information on detailed habitat assessments, 2009.

[ft $3 / s$, cubic feet per second; ADCP, Acoustic Doppler current profiler]

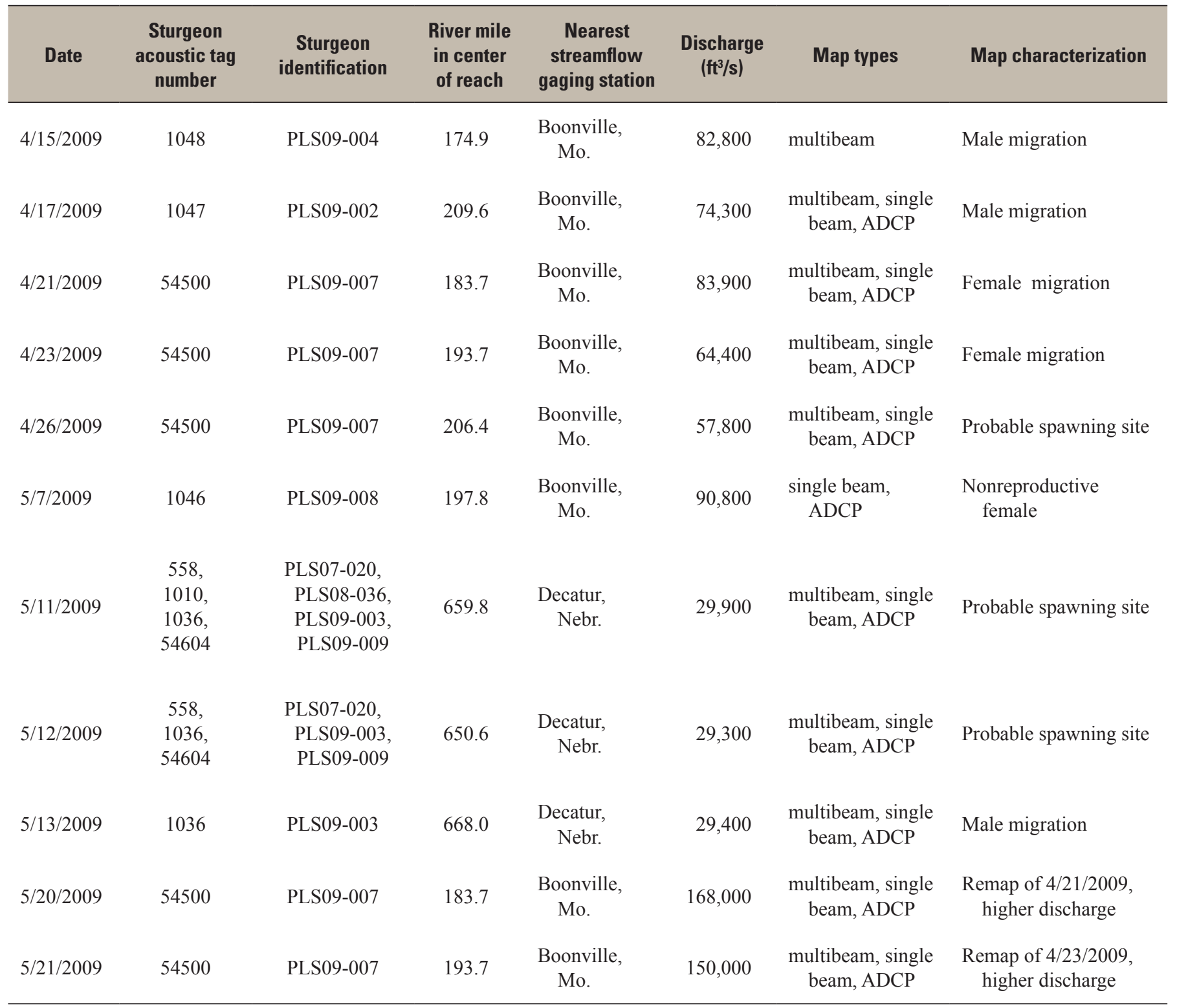




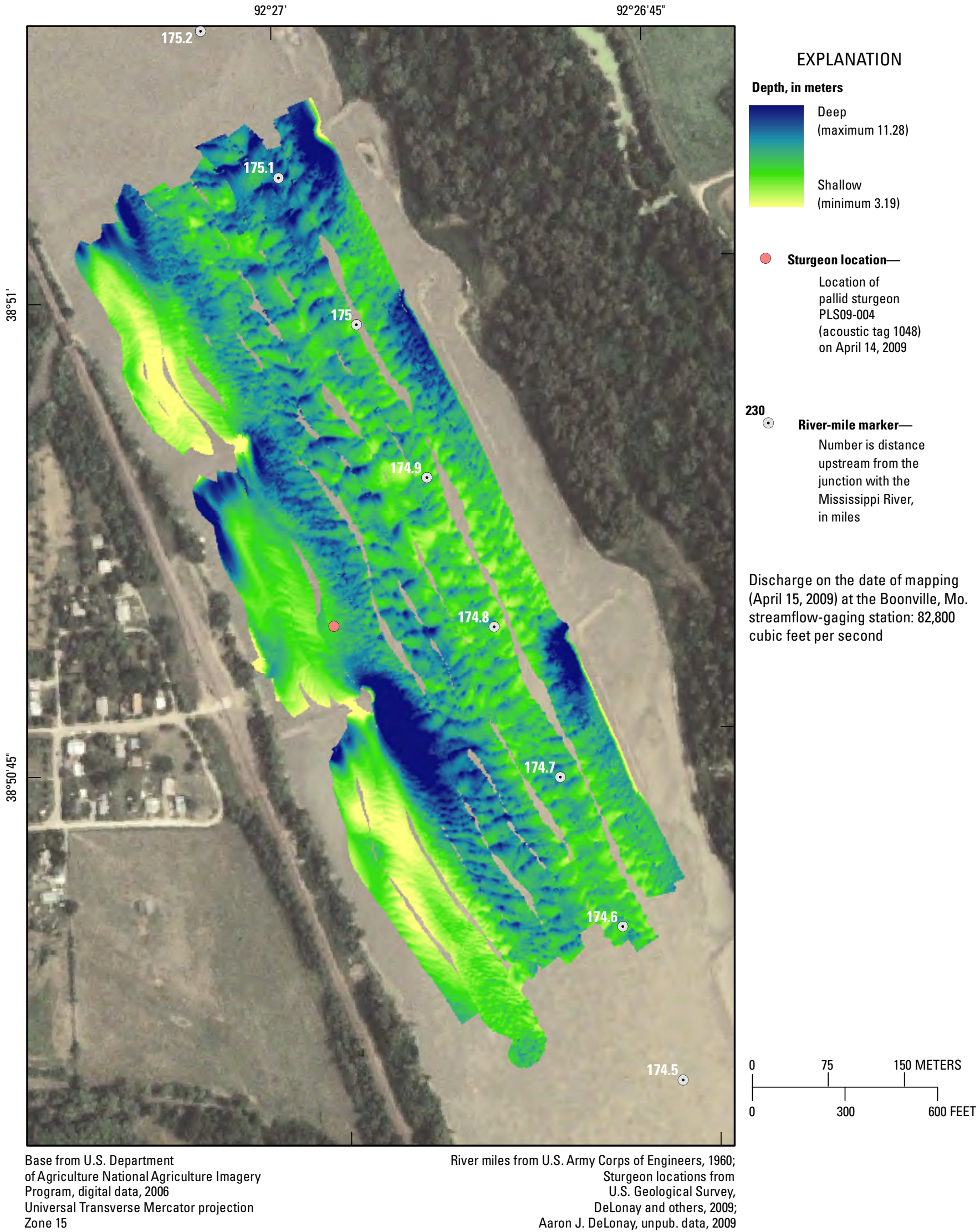

Figure 11. Multibeam bathymetric map of location of migrating male pallid sturgeon PLS09-004, acoustic tag 1048. Mapped April 15, 2009. 


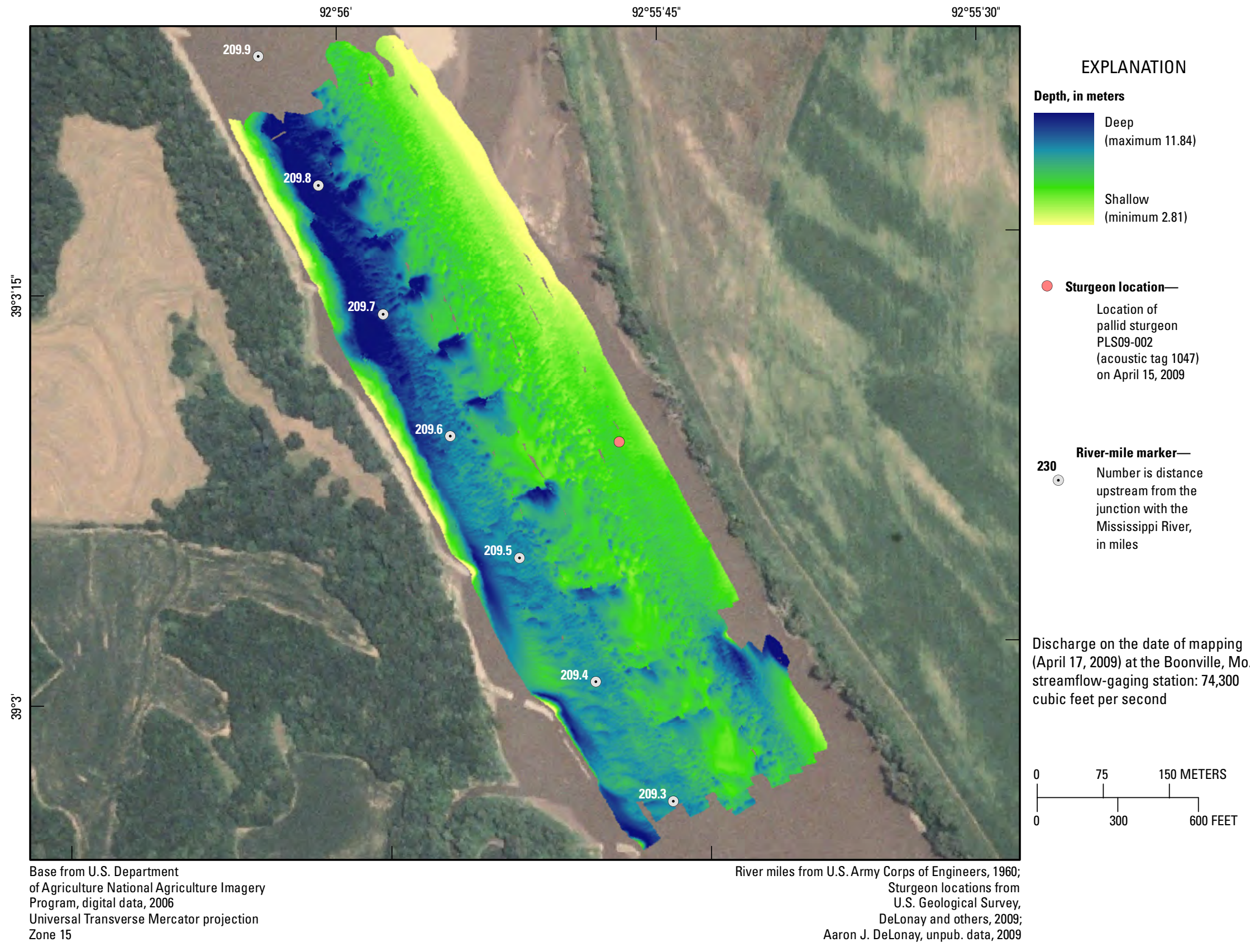

Figure 12. Multibeam bathymetric map of location of migrating male pallid sturgeon PLS09-002, acoustic tag 1047. Mapped April 17, 2009. 


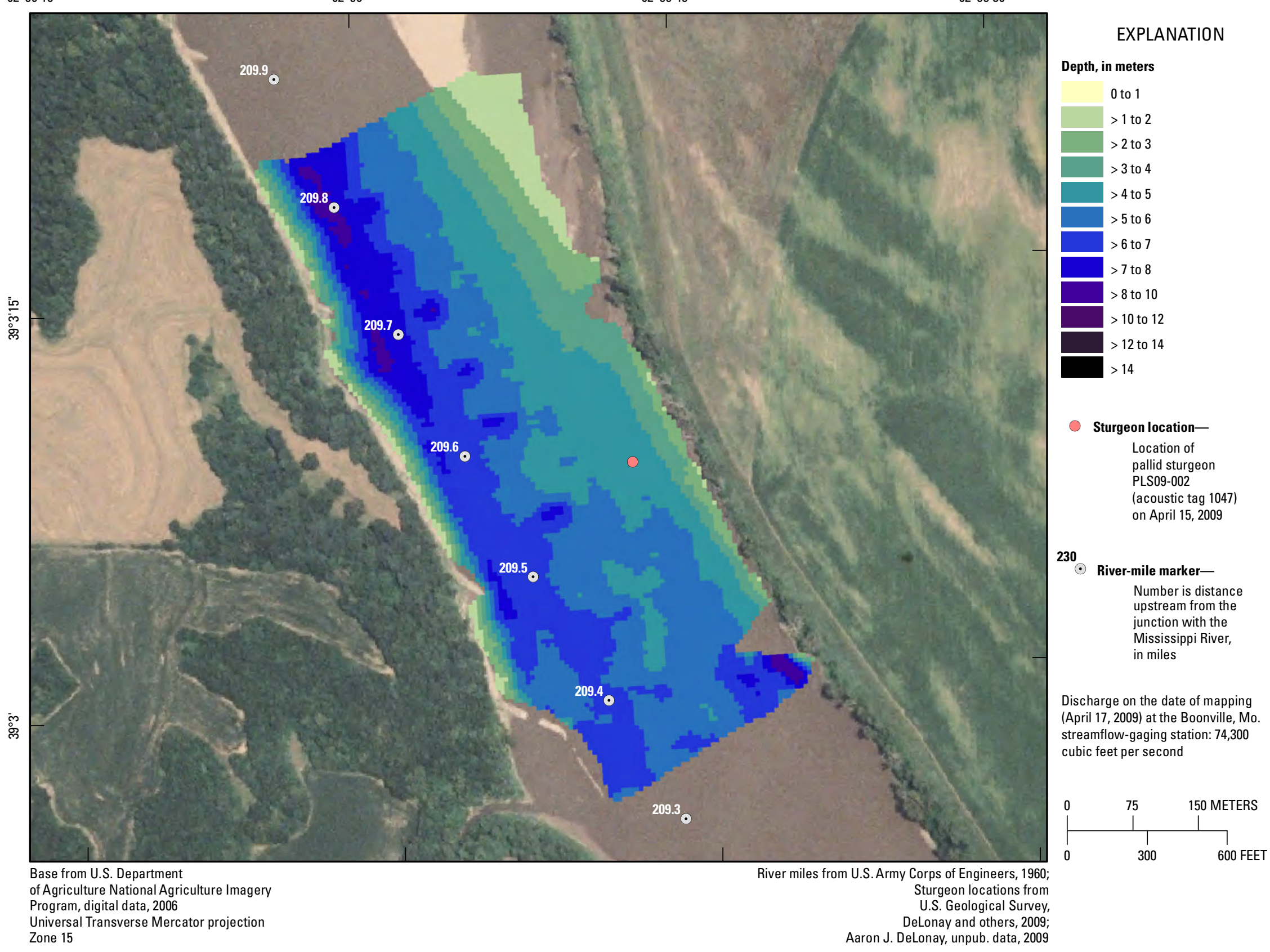

Figure 13. Single-beam depth map of location of migrating male pallid sturgeon PLS09-002, acoustic tag 1047. Mapped April 17, 2009. 


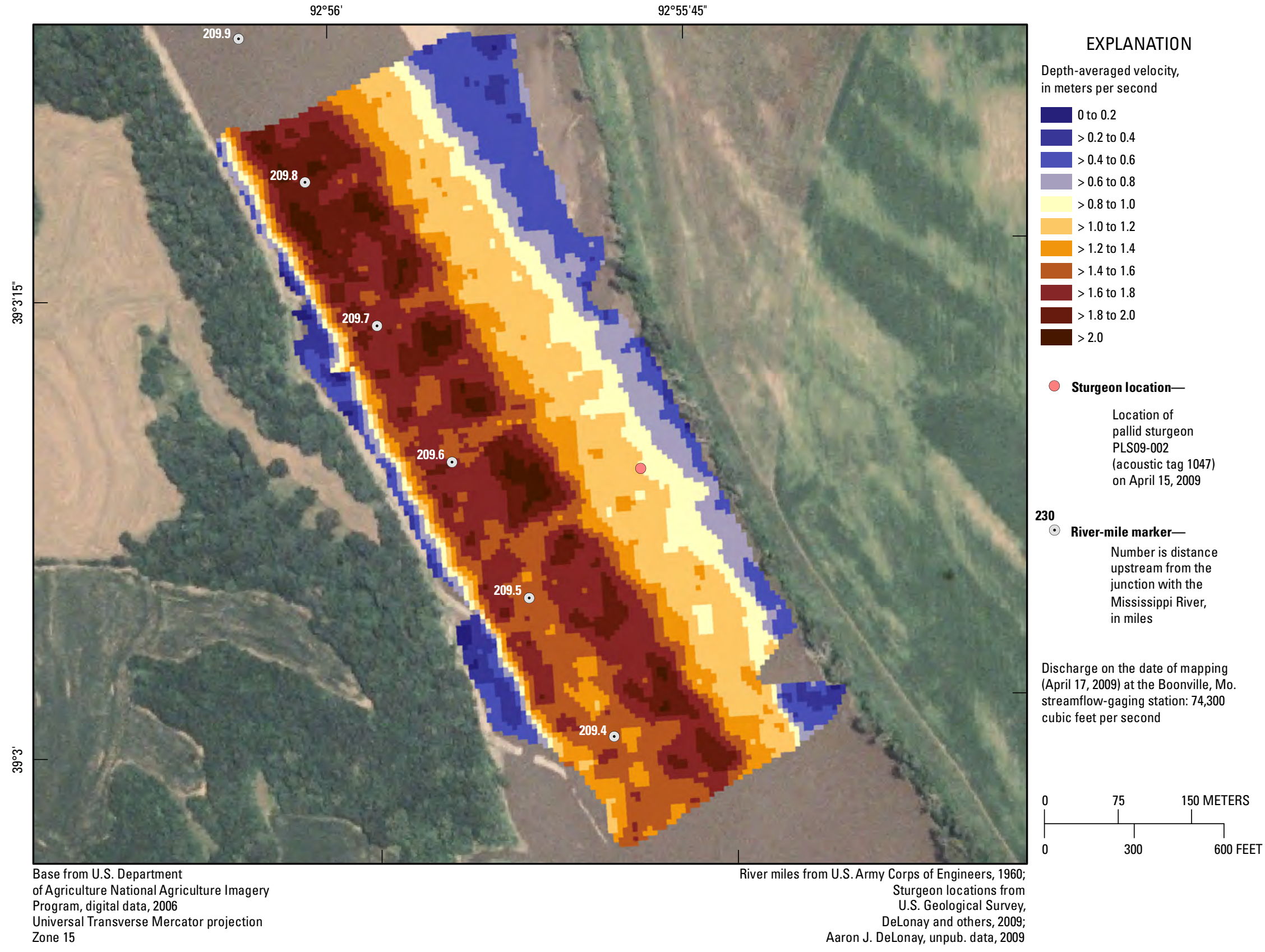

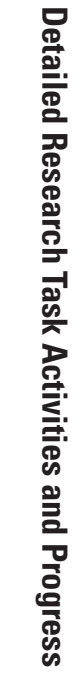

Figure 14. Acoustic Doppler current profiler velocity map of location of migrating male pallid sturgeon PLS09-002, acoustic tag 1047. Mapped April 17, 2009. 


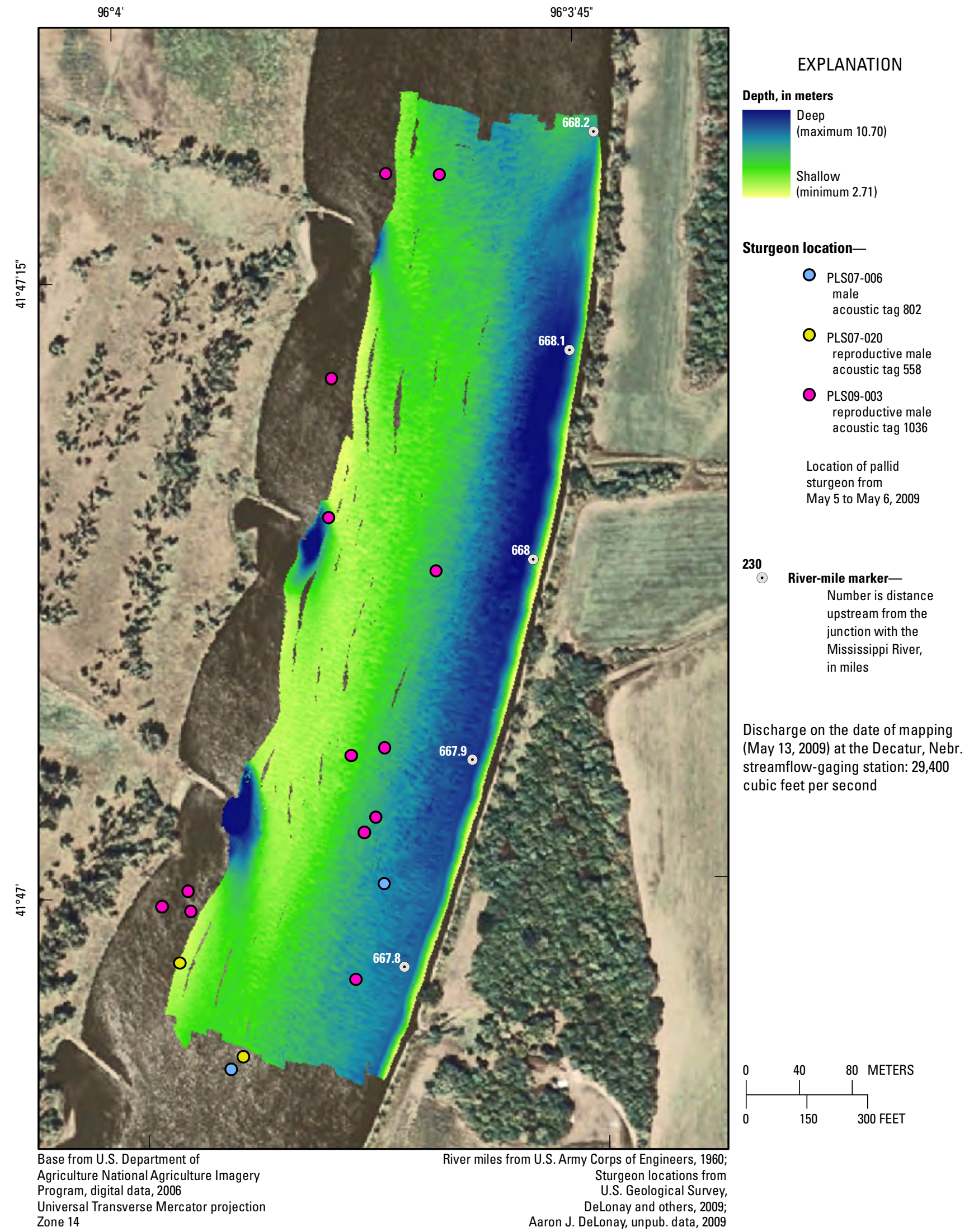

Figure 15. Multibeam bathymetric map of location of migrating male pallid sturgeon PLS09-003, acoustic tag 1036, along with reproductive male PLS07-020, acoustic tag 558, and male PLS07-006, acoustic tag 802. Mapped May 13, 2009. 


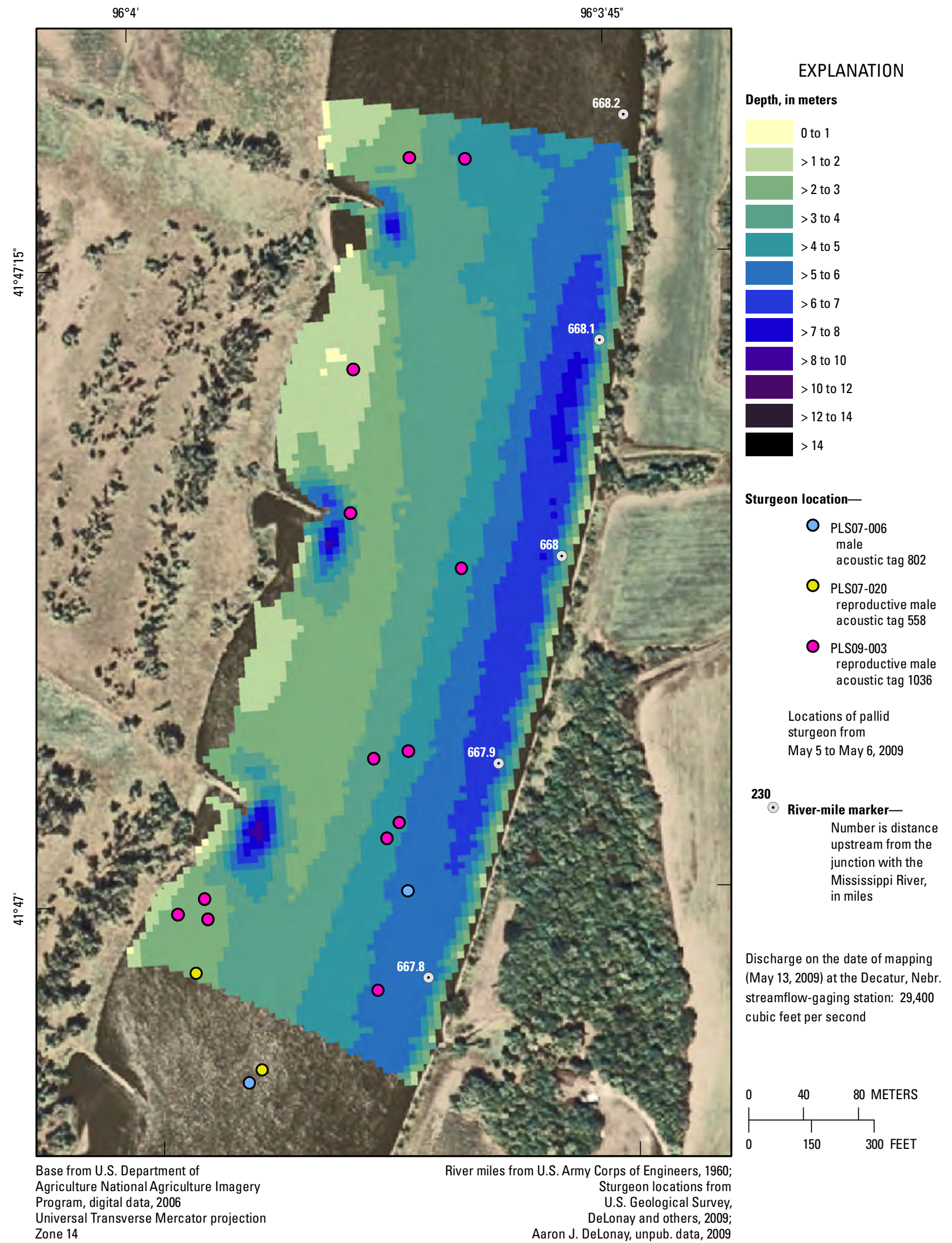

Figure 16. Single-beam depth map of location of migrating male pallid sturgeon PLS09-003, acoustic tag 1036, along with reproductive male PLS07-020, acoustic tag 558, and male PLS07-006, acoustic tag 802. Mapped May 13, 2009. 


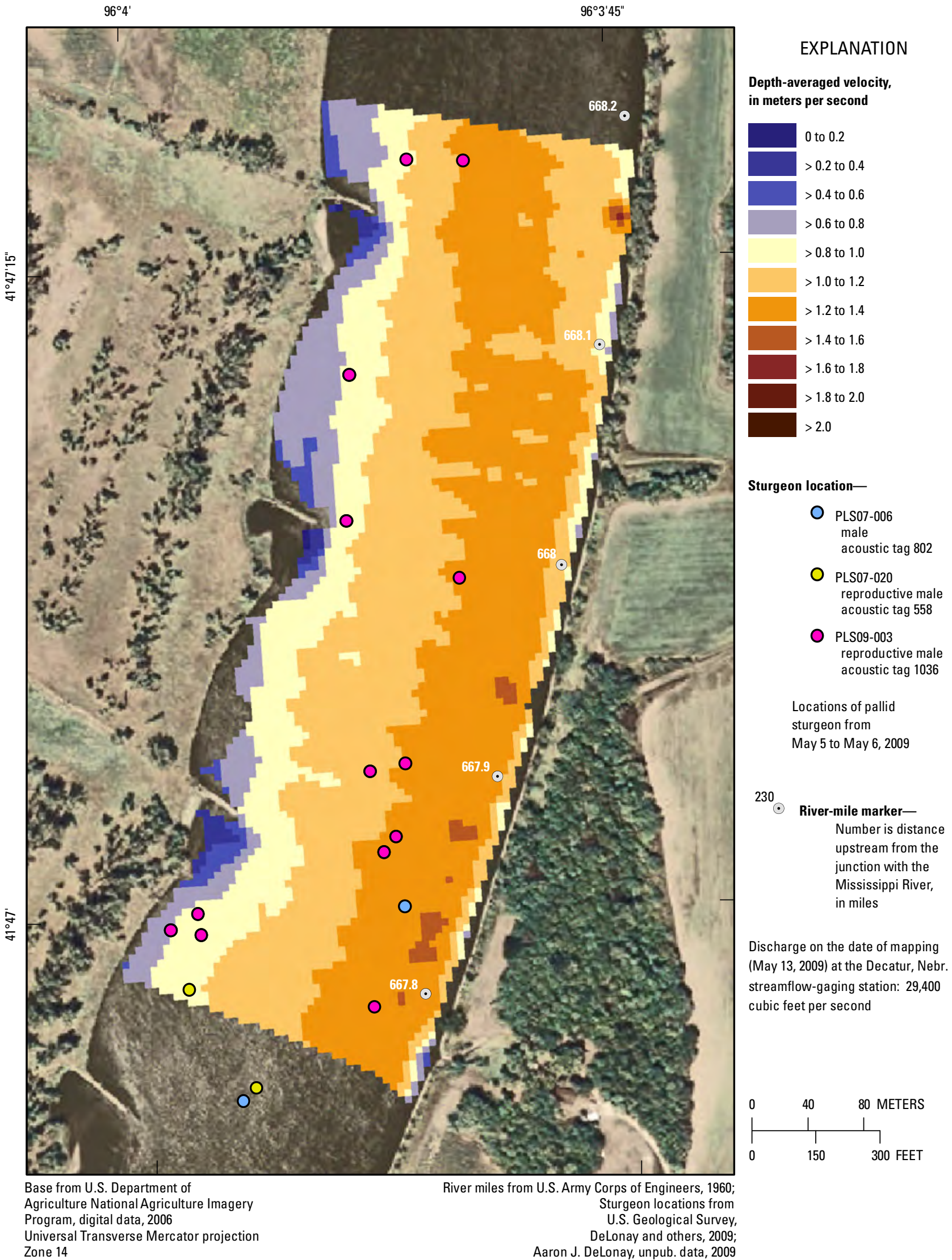

Figure 17. Acoustic Doppler current profiler velocity map of location of migrating male pallid sturgeon PLS09-003, acoustic tag 1036, along with reproductive male PLS07-020, acoustic tag 558, and male PLS07-006, acoustic tag 802. Mapped May 13, 2009. 


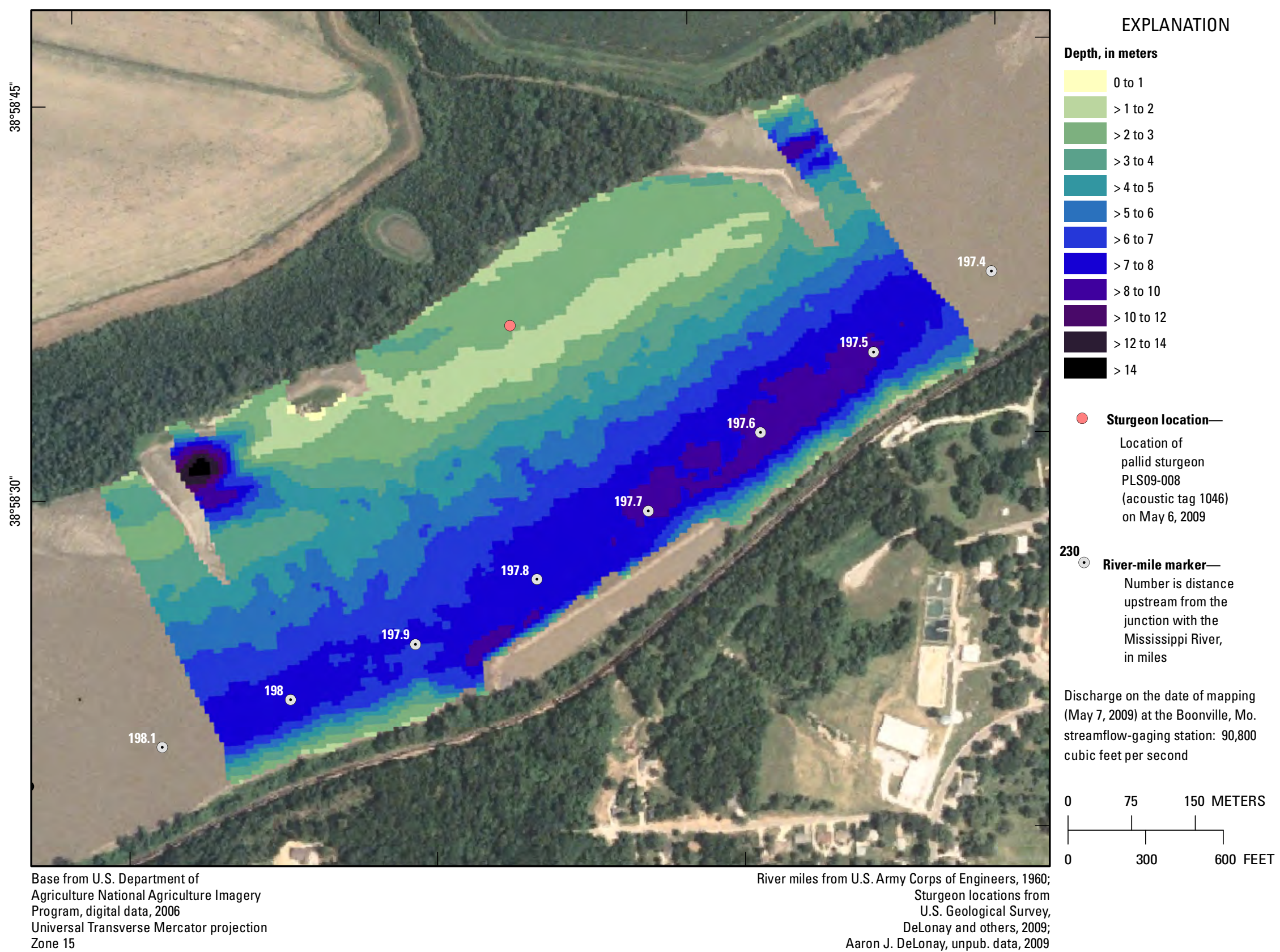




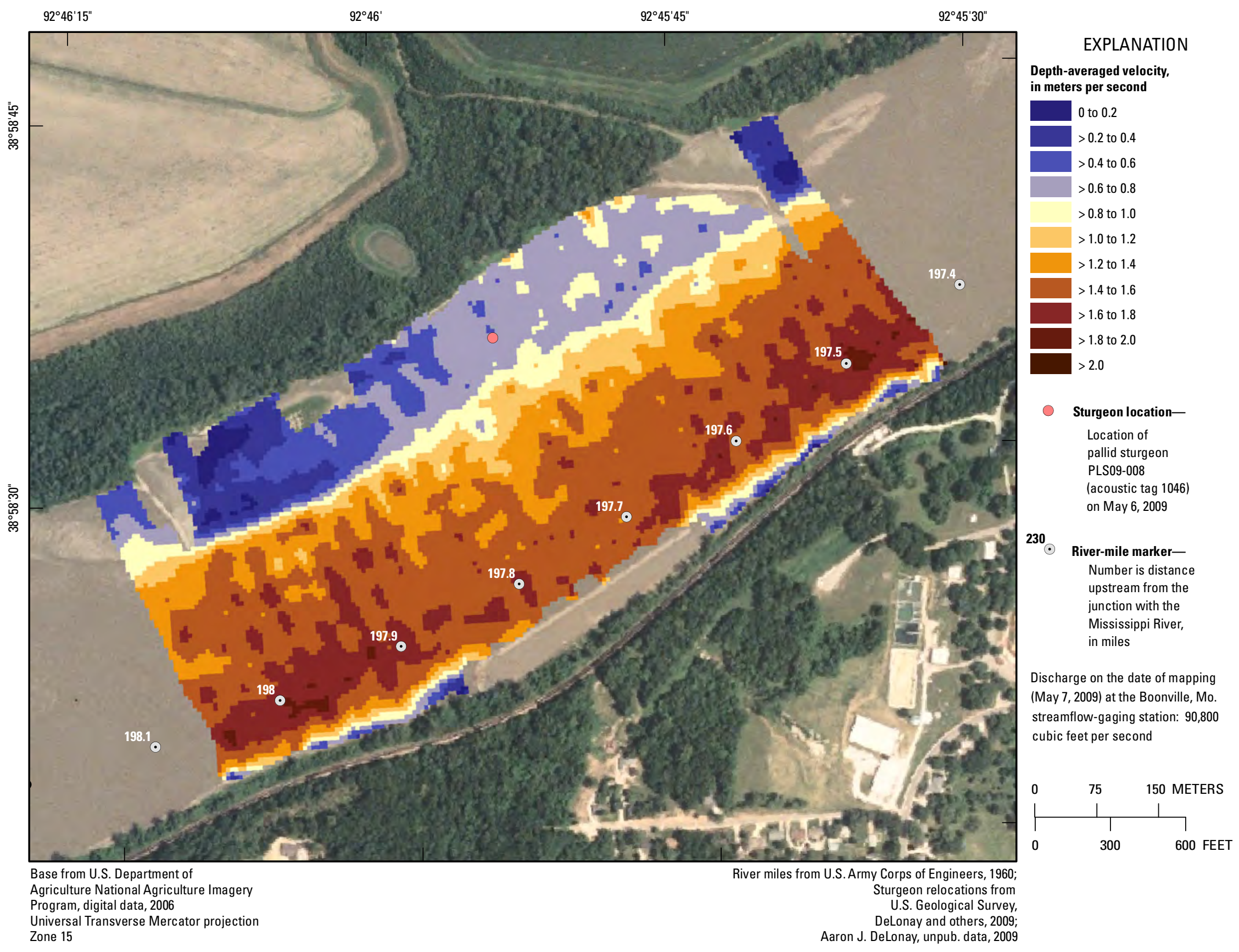

Figure 19. Acoustic Doppler current profiler velocity map of location of migrating male pallid sturgeon PLS09-008, acoustic tag 1046. Mapped May 7, 2009. 


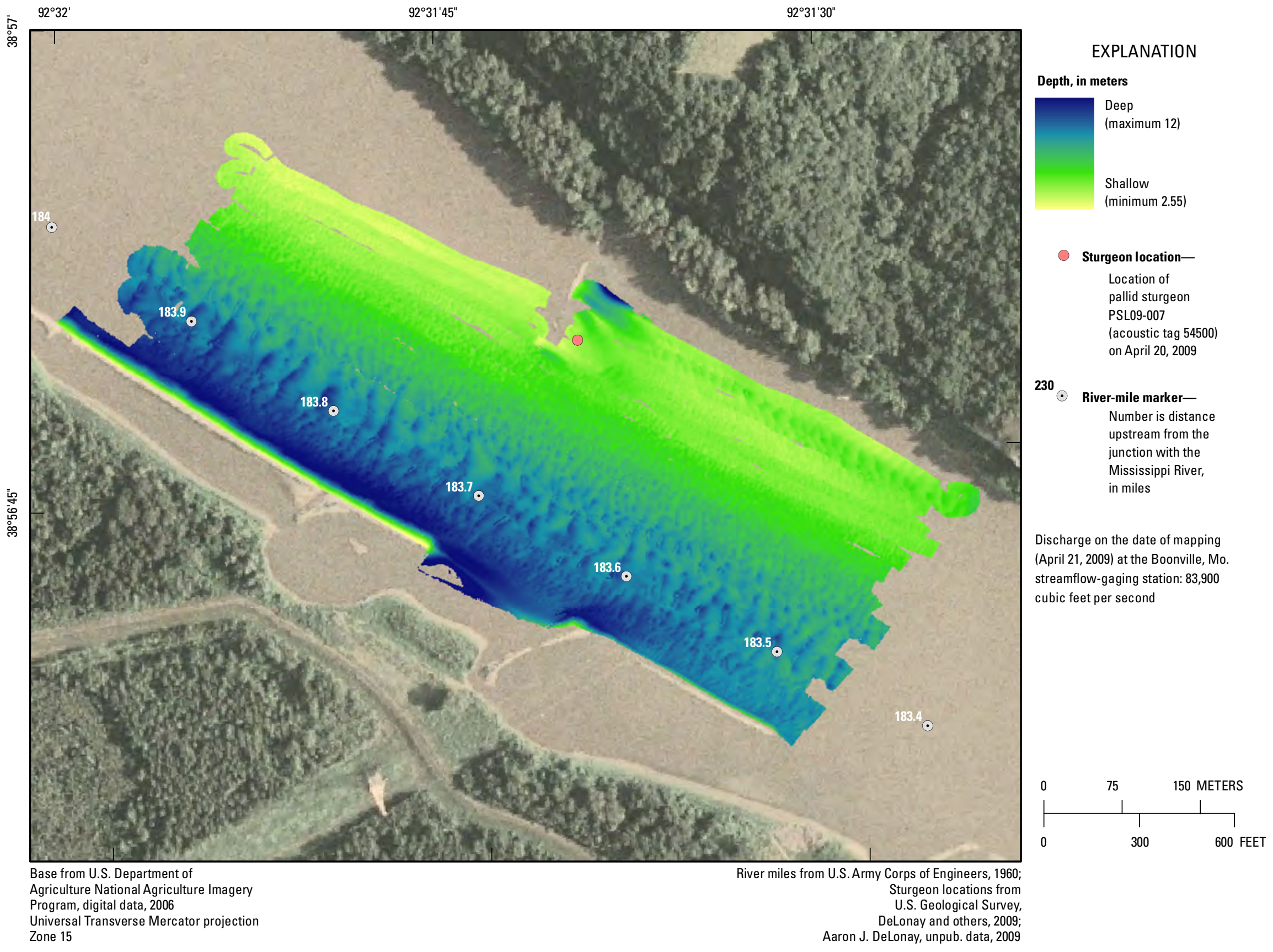

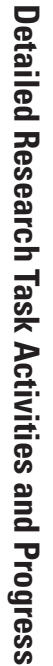

Figure 20. Multibeam bathymetric map of location of migrating female pallid sturgeon PLS09-007, acoustic tag 54500. Mapped April 21, 2009. 


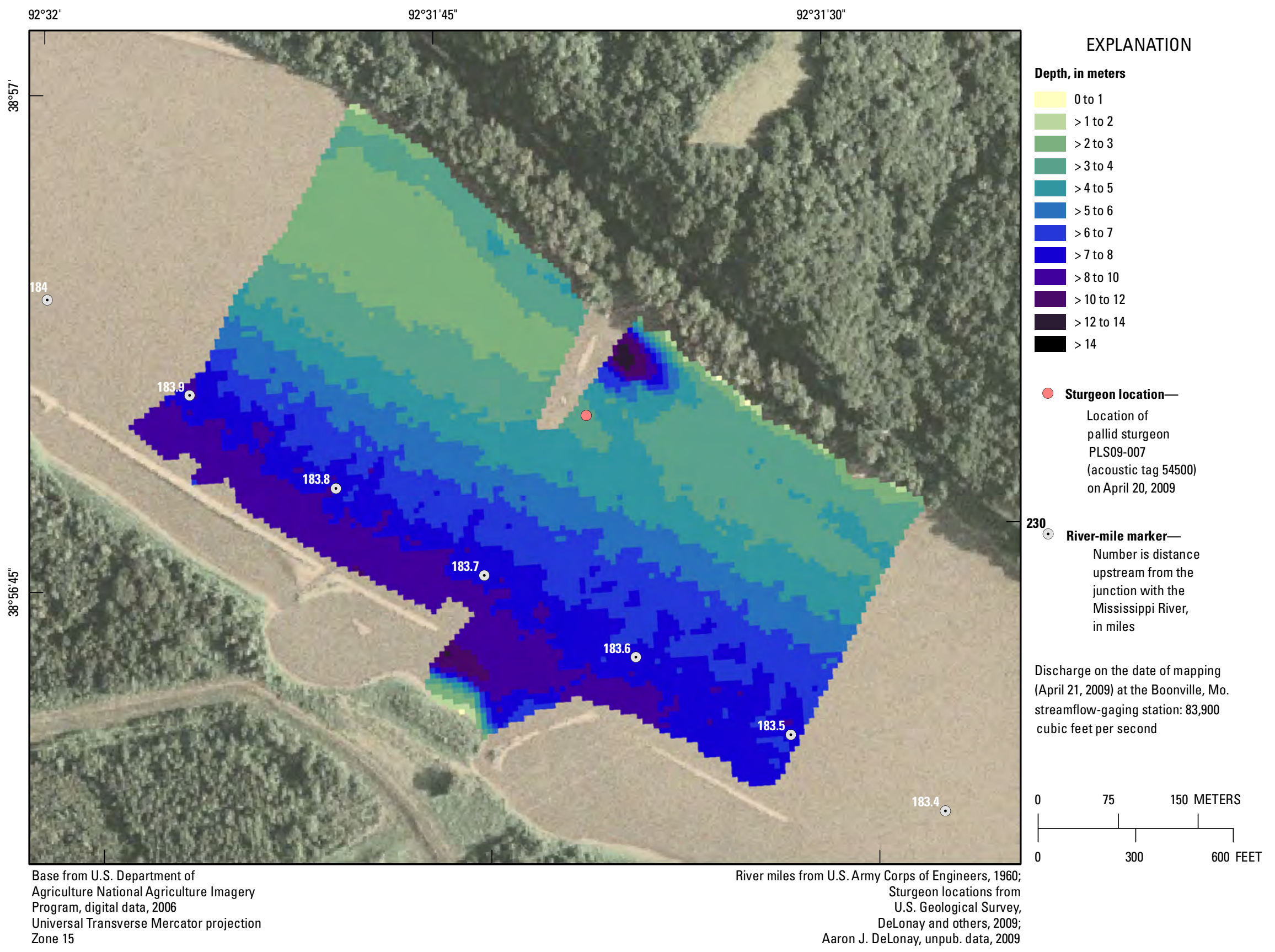

Figure 21. Single-beam depth map of location of migrating female pallid sturgeon PLS09-007, acoustic tag 54500. Mapped April 21, 2009. 


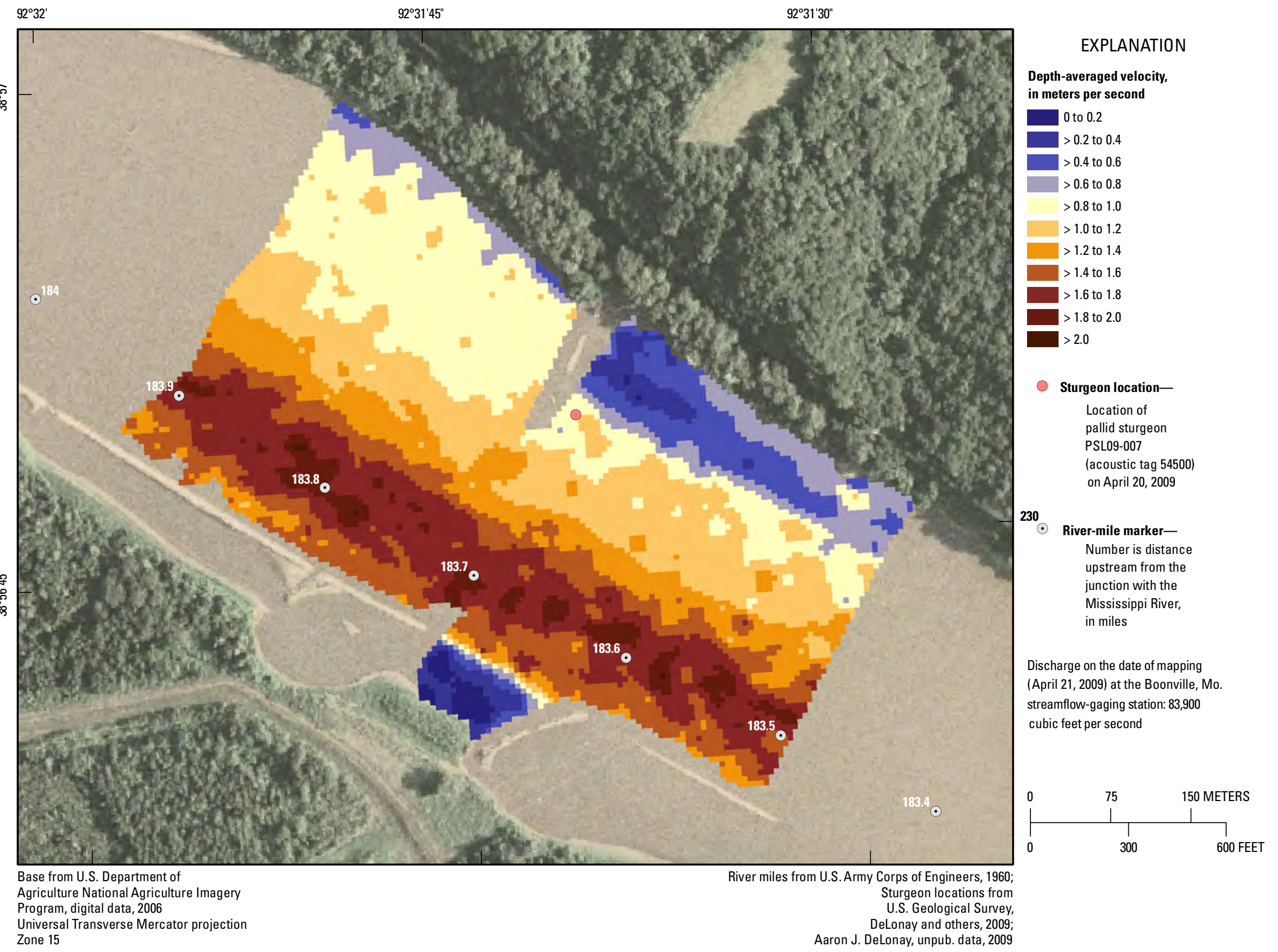

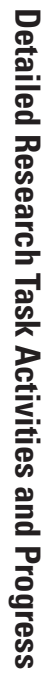

Figure 22. Acoustic Doppler current profiler velocity map of location of migrating female pallid sturgeon PLS09-007, acoustic tag 54500. Mapped April 21, 2009. 


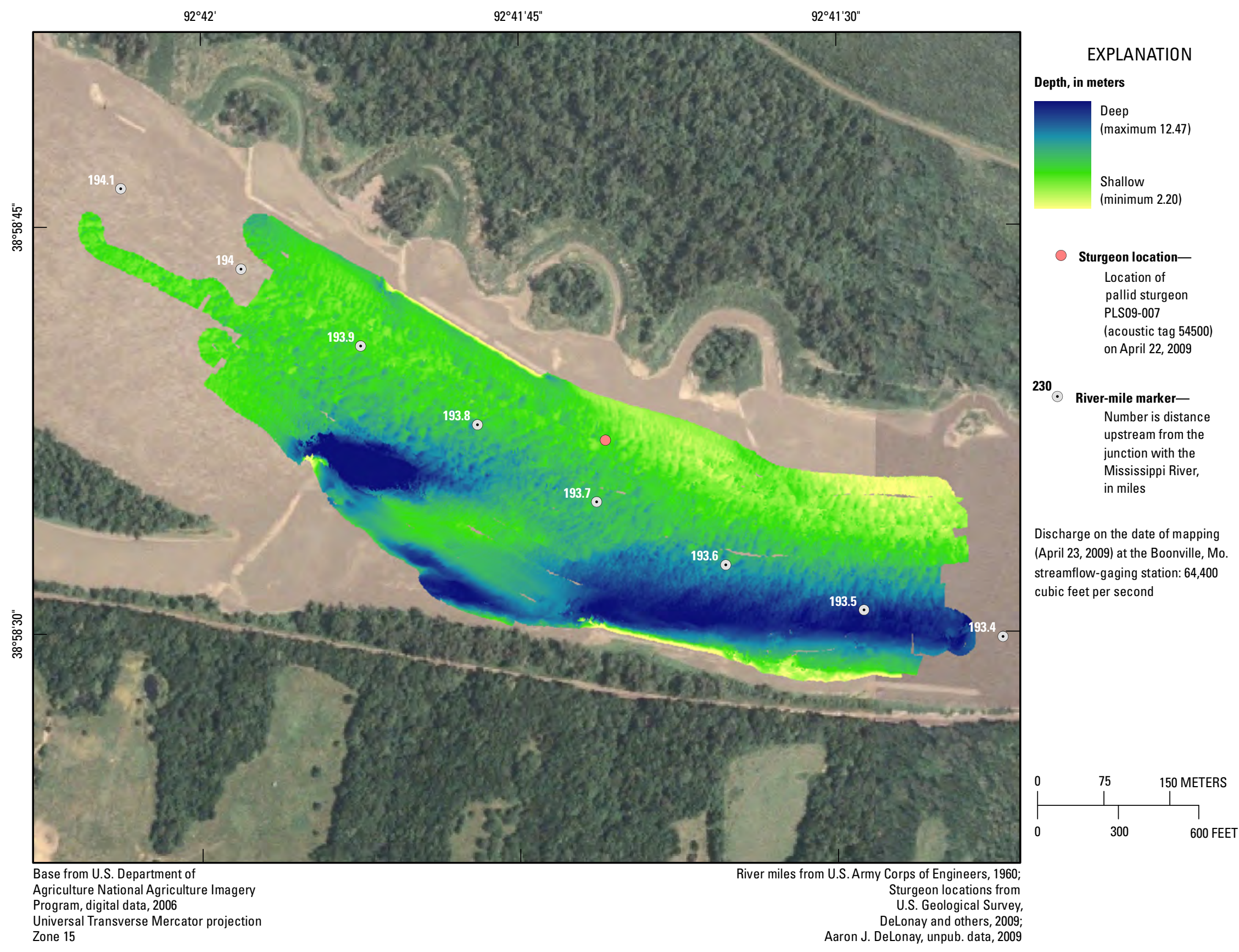

Figure 23. Multibeam bathymetric map of location of migrating female pallid sturgeon PLS09-007, acoustic tag 54500. Mapped April 23, 2009. 


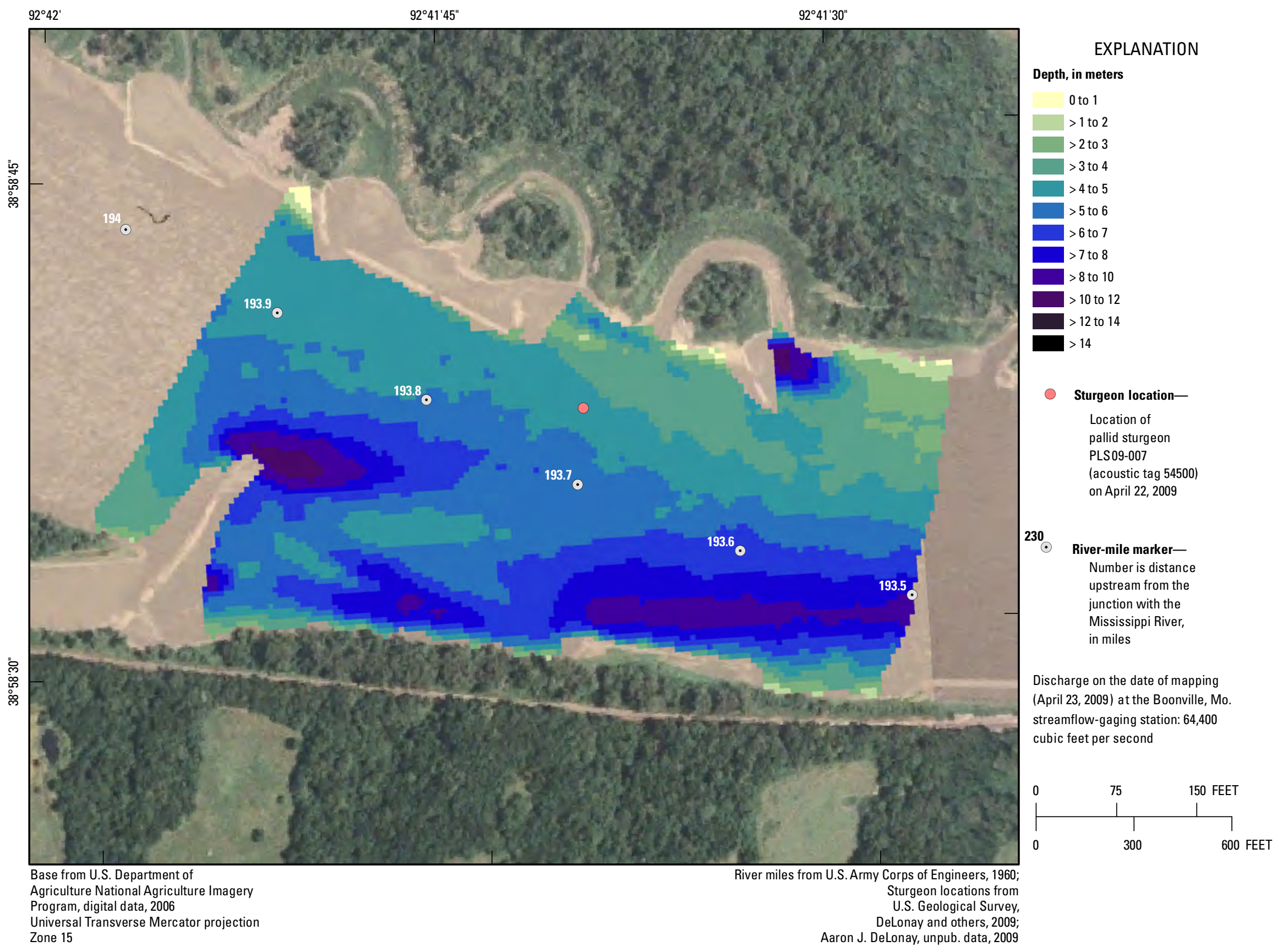

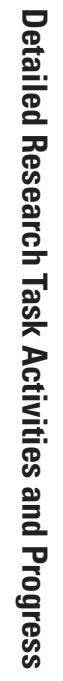

Figure 24. Single-beam depth map of location of migrating female pallid sturgeon PLS09-007, acoustic tag 54500. Mapped April 23, 2009. 


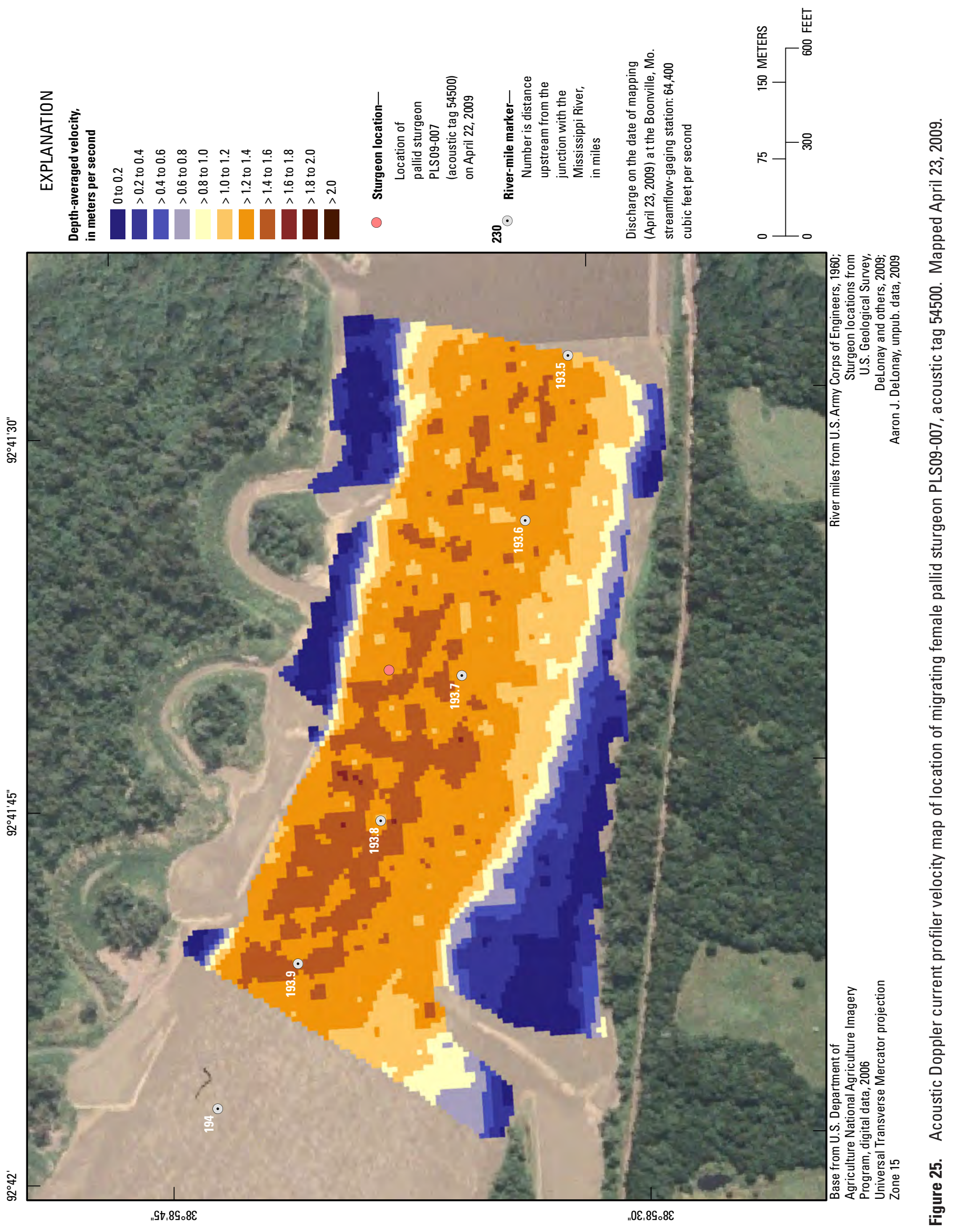




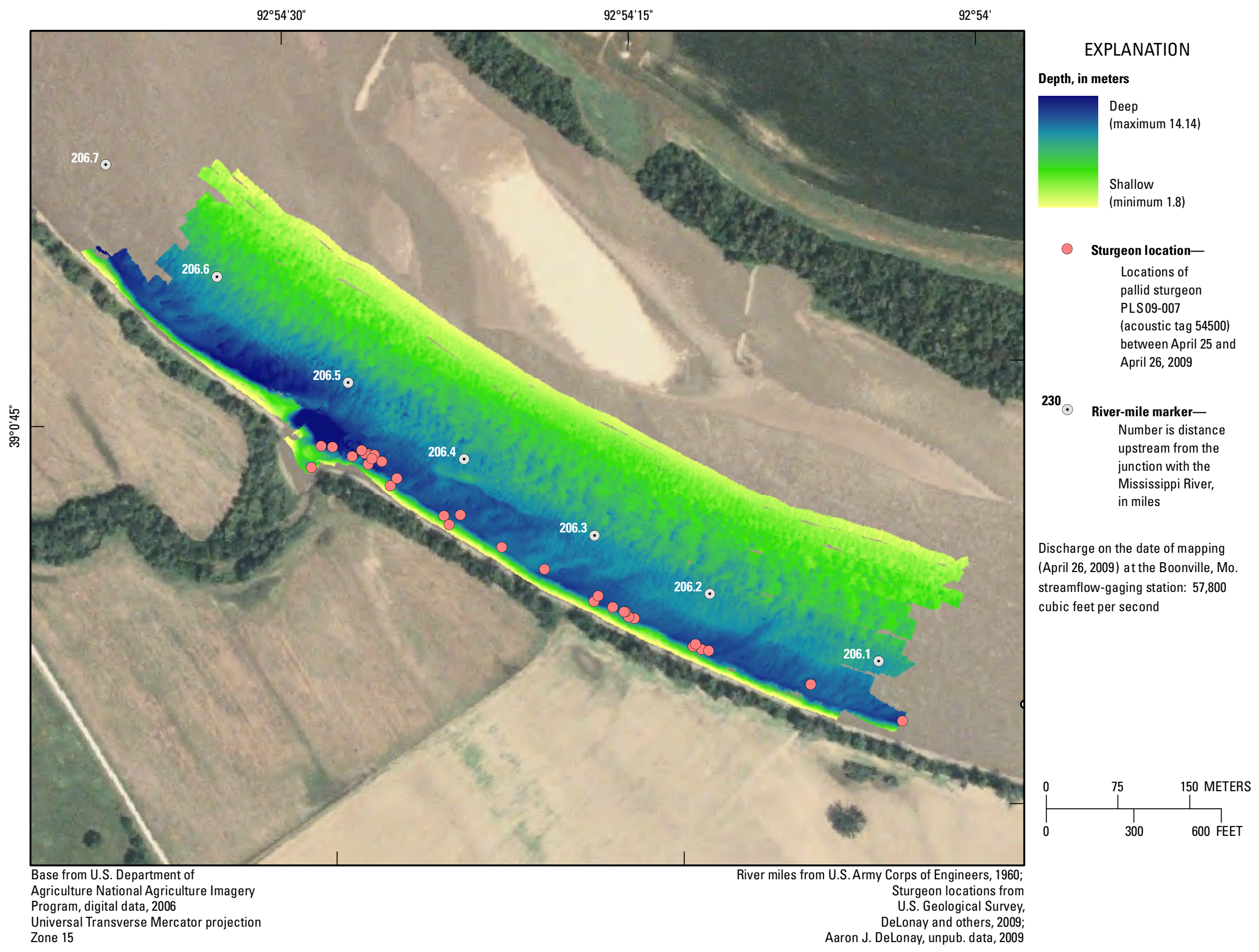

Figure 26. Multibeam bathymetric map of location of probable spawning site of female pallid sturgeon PLS09-007, acoustic tag 54500. Mapped April 26, 2009. 


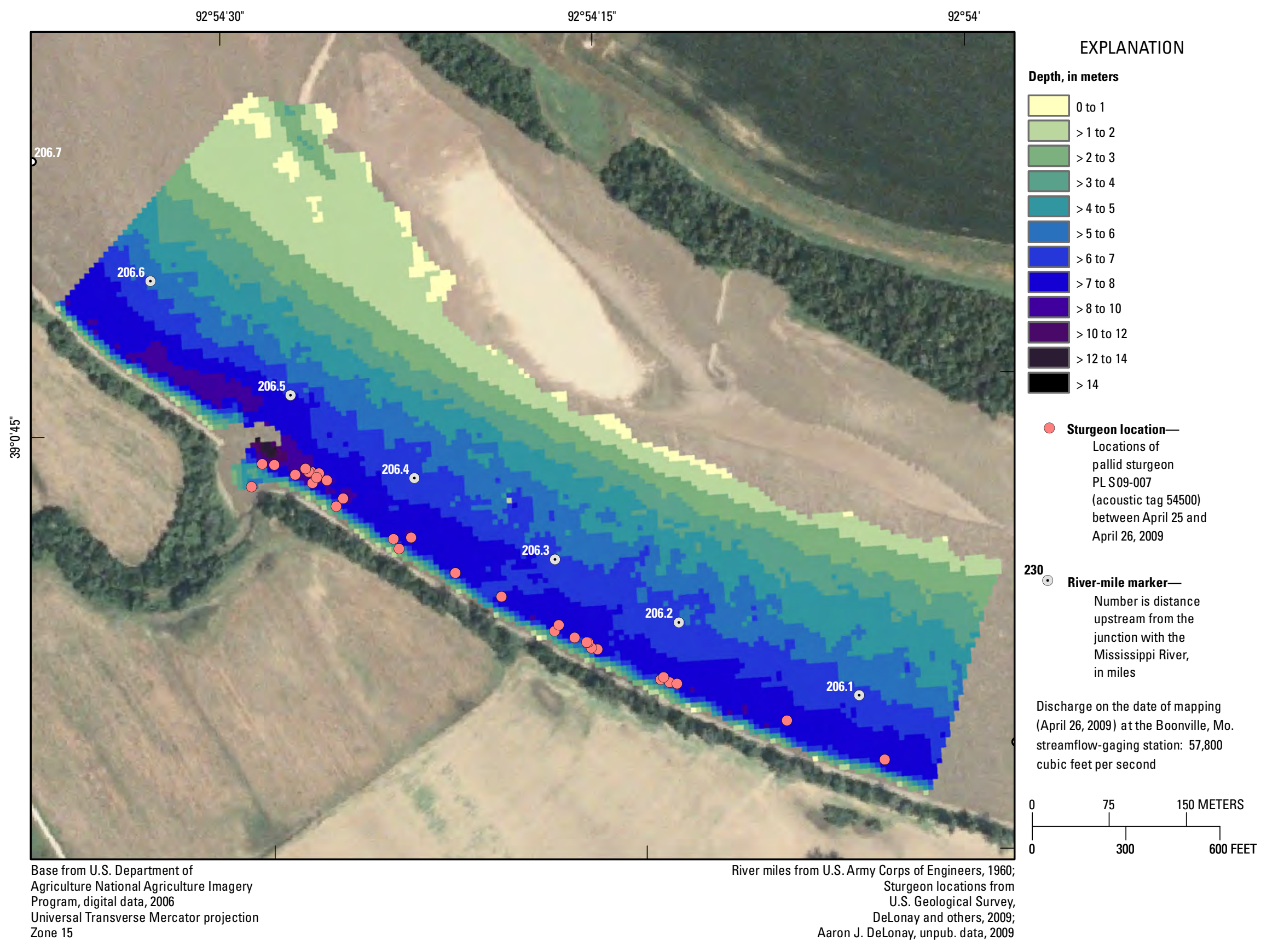

Figure 27. Single-beam depth map of location of probable spawning site of female pallid sturgeon PLS09-007, acoustic tag 54500. Mapped April 26, 2009. 


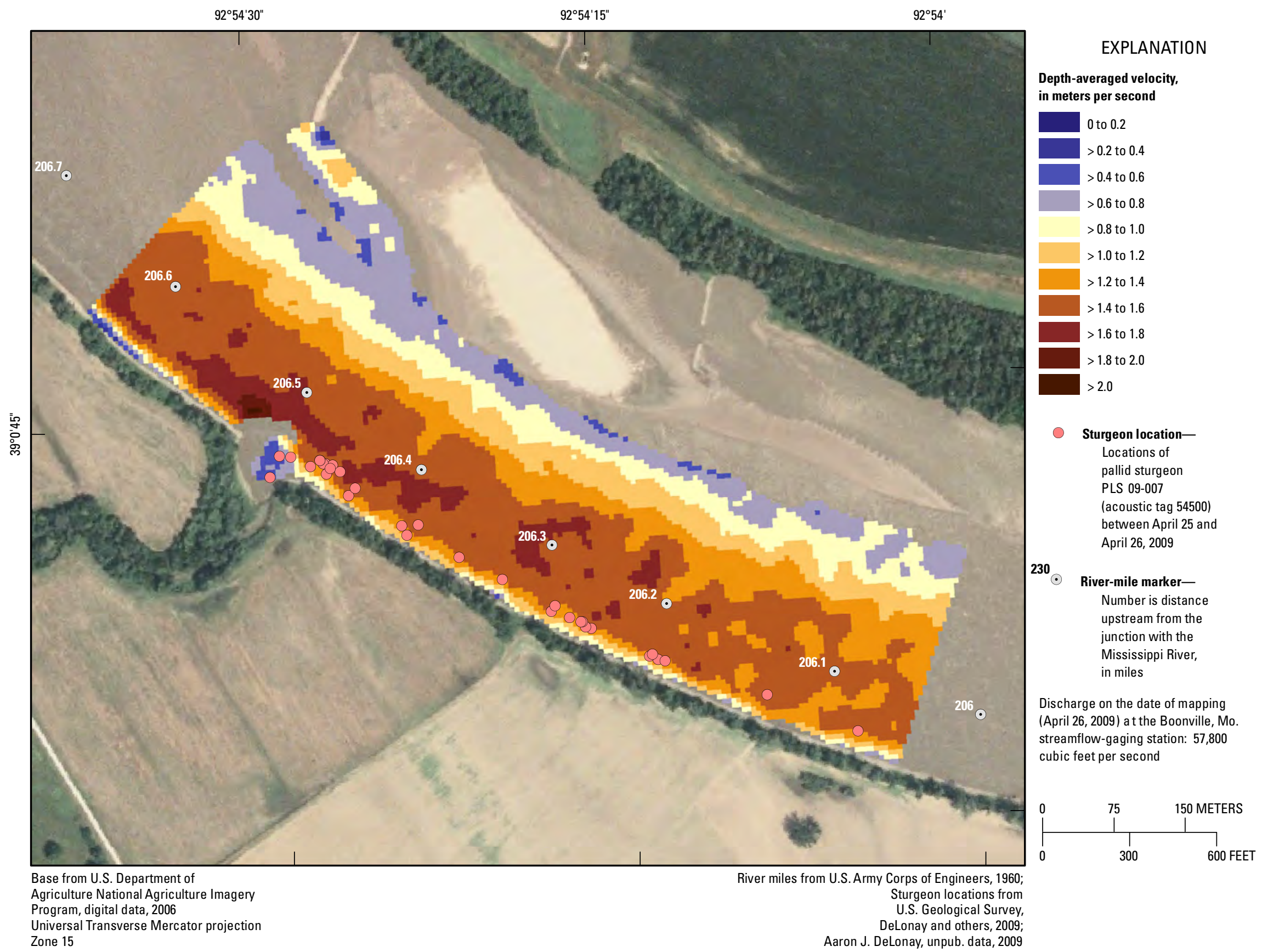

Figure 28. Acoustic Doppler current profiler velocity map of location of probable spawning site of female pallid sturgeon PLS09-007, acoustic tag 54500. Mapped April 26, 2009. 


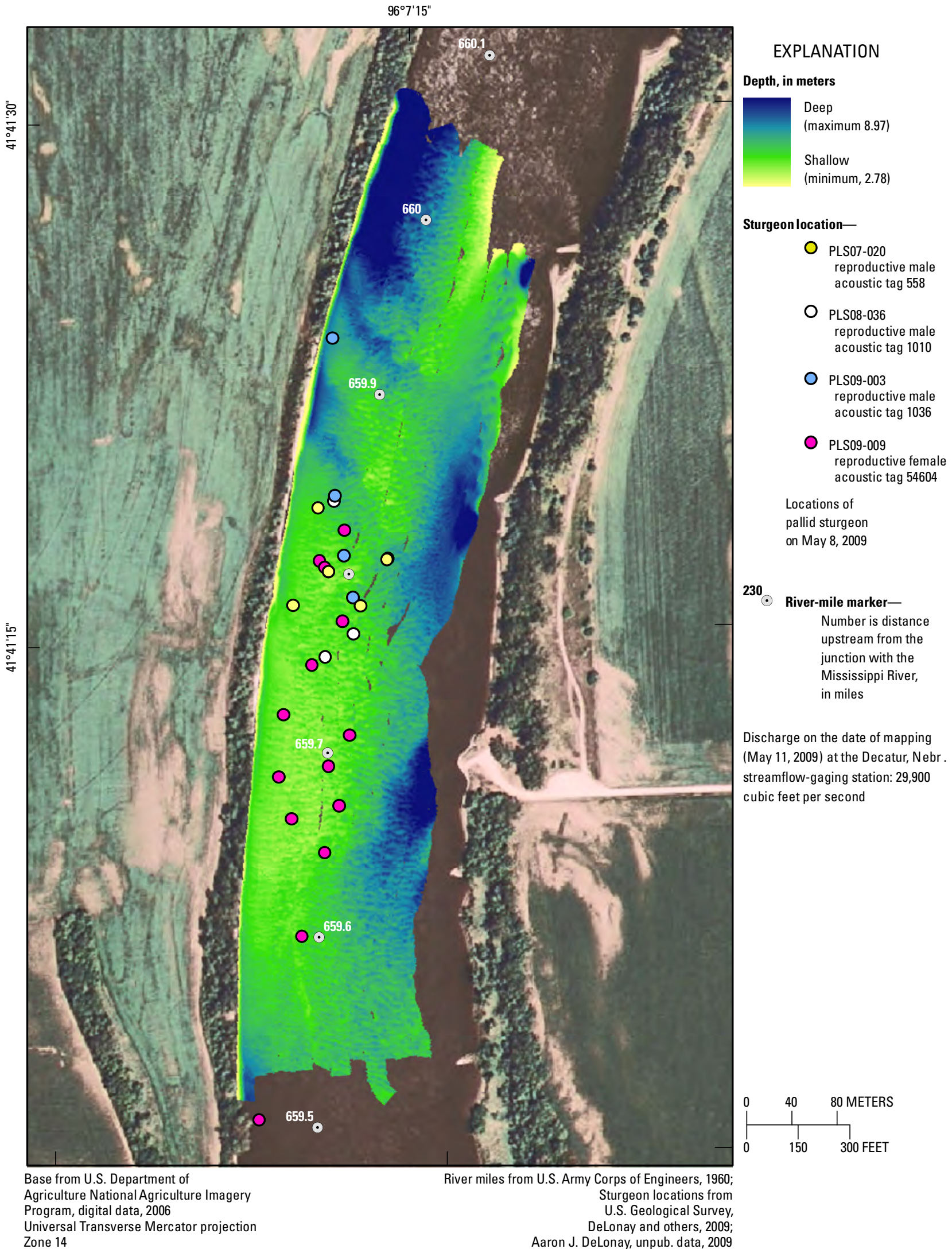

Figure 29. Multibeam bathymetric map of location of probable spawning site of female pallid sturgeon PLS09-009, acoustic tag 54604, along with reproductive males PLS07-020, acoustic tag 558, PLS08-036, acoustic tag 1010, and PLS09-003, acoustic tag 1036. Mapped May 11, 2009. 
$96^{\circ} 7^{\prime} 15^{\prime \prime}$

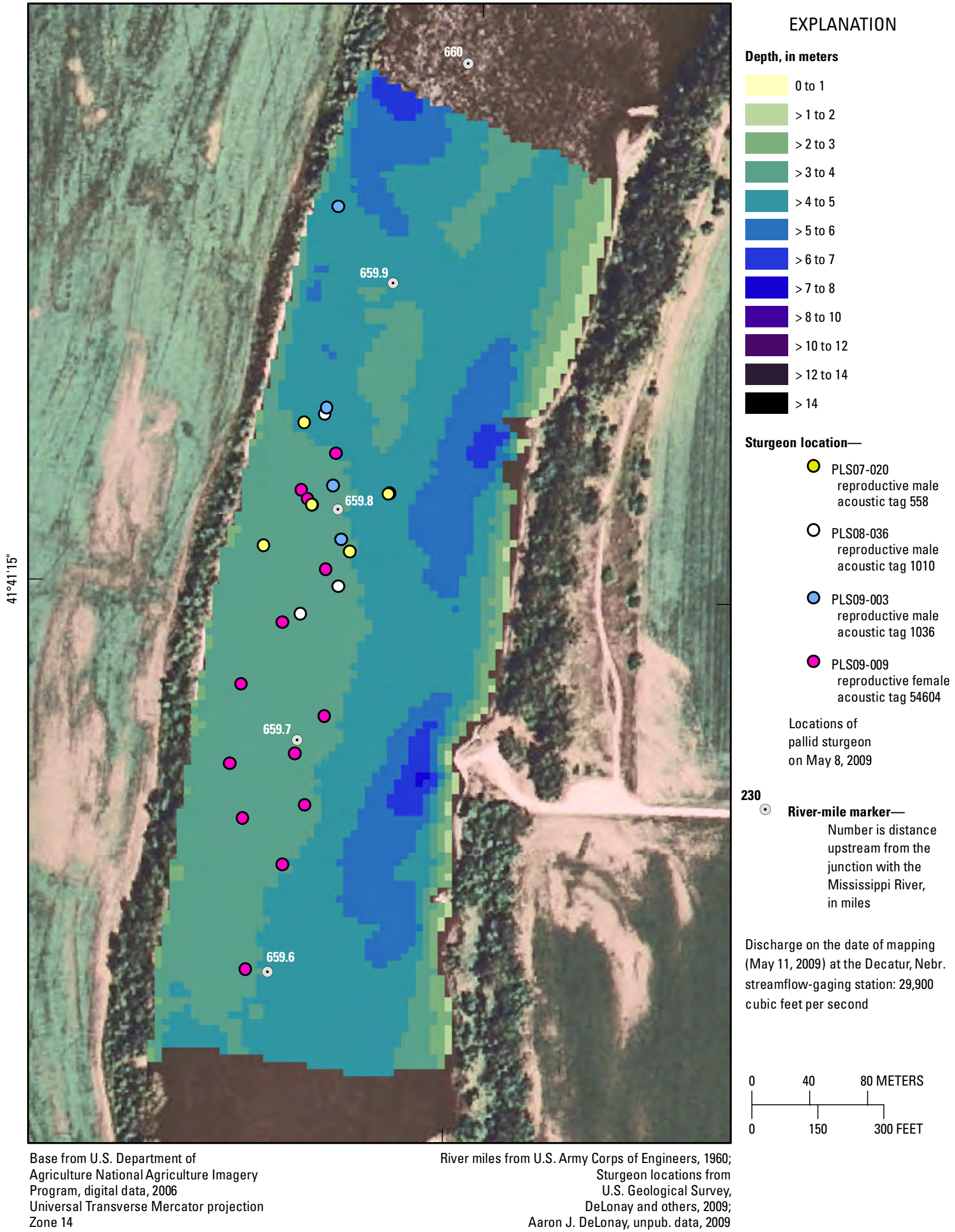

Figure 30. Single-beam depth map of location of probable spawning site of female pallid sturgeon PLS09-009, acoustic tag 54604 along with reproductive males PLS07-020, acoustic tag 558, PLS08-036, acoustic tag 1010, and PLS09-003, acoustic tag 1036. Mapped May 11, 2009. 


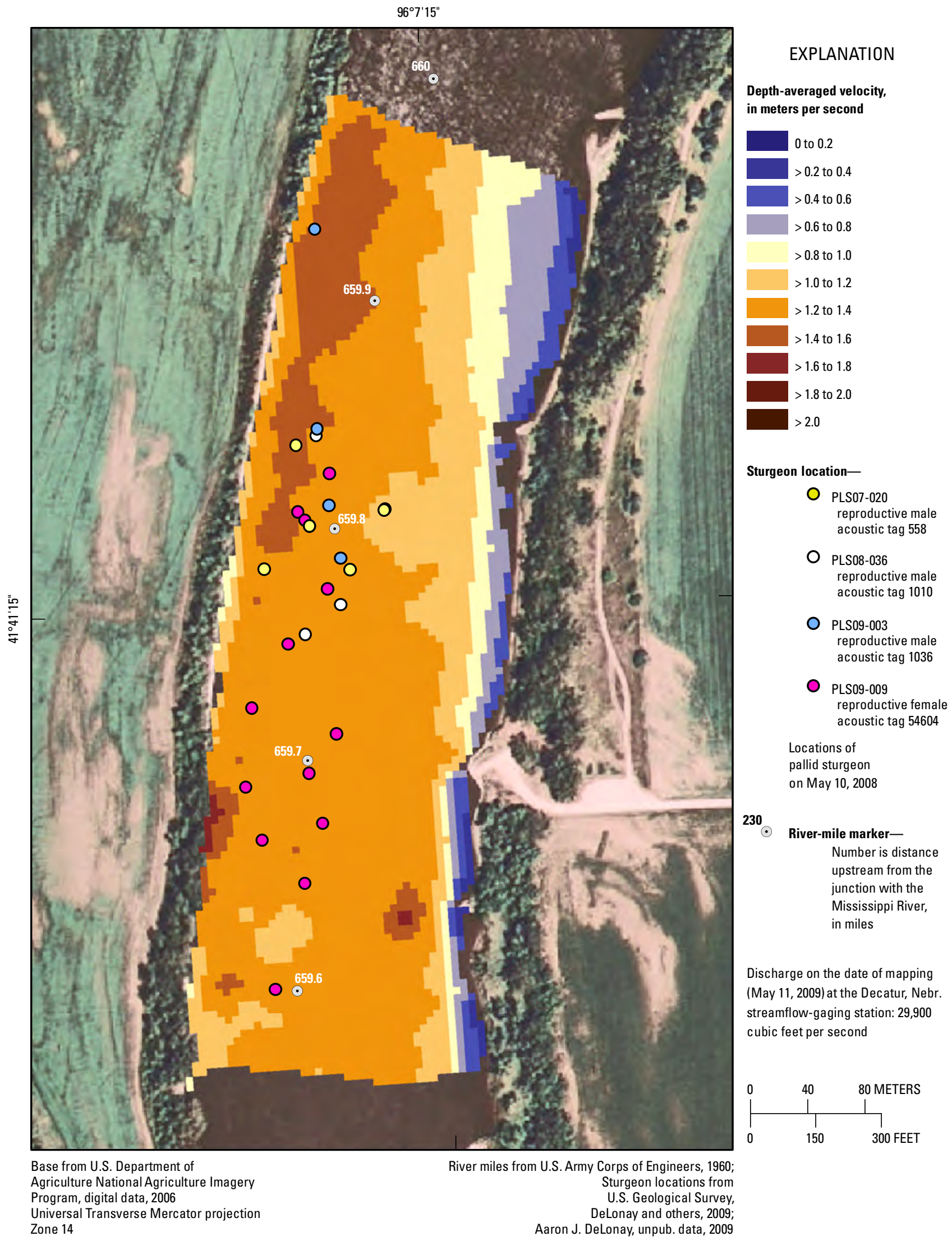

Figure 31. Acoustic Doppler current profiler velocity map of probable spawning site of female pallid sturgeon PLS09-009, acoustic tag 54604 along with reproductive males PLS07-020, acoustic tag 558, PLS08-036, acoustic tag 1010, and PLS09-003, acoustic tag 1036. Mapped May 11, 2009. 


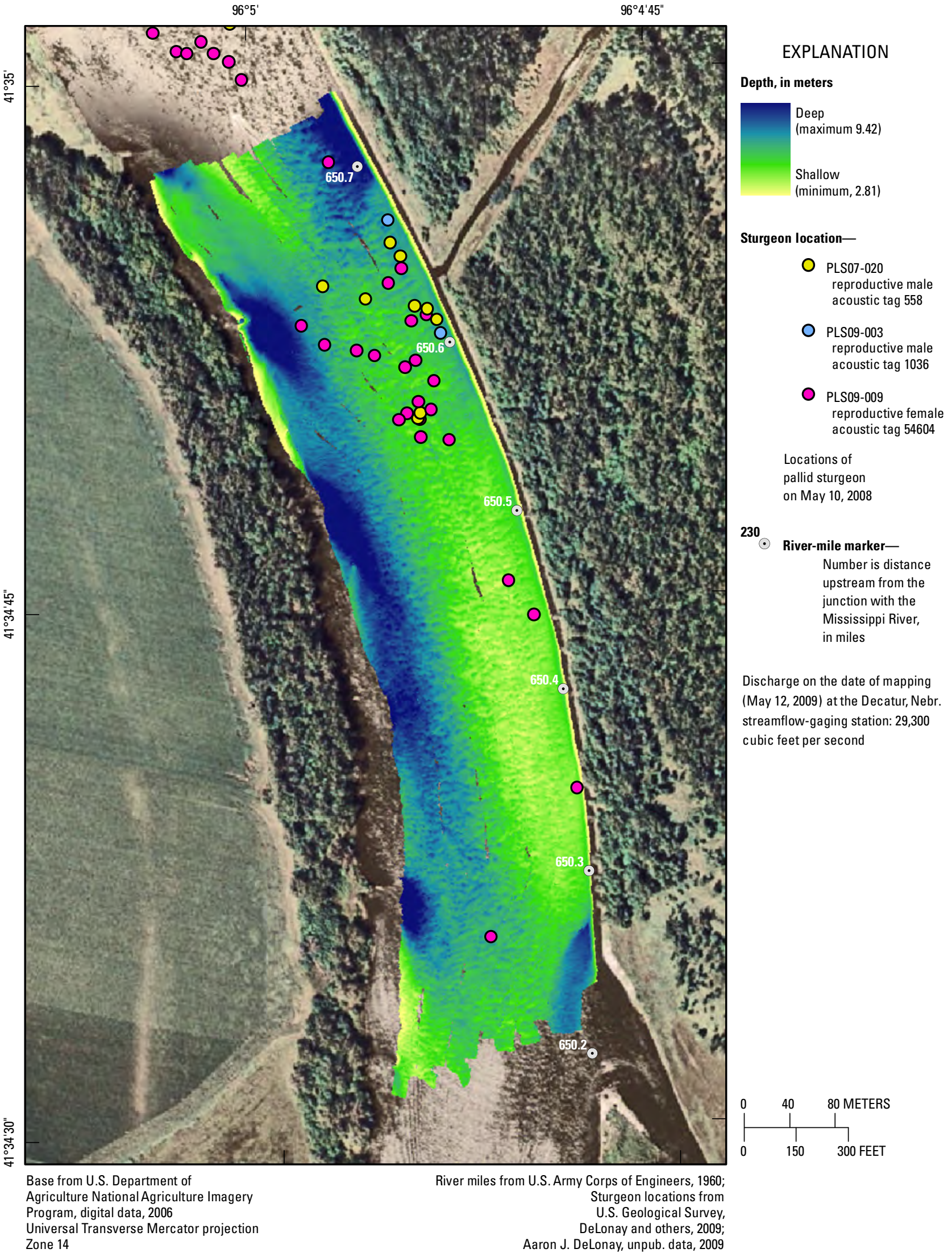

Figure 32. Multibeam bathymetric map of location of probable spawning site of female pallid sturgeon PLS09-009, acoustic tag 54604, along with reproductive males PLS07-020, acoustic tag 558, and PLS09-003, acoustic tag 1036. Mapped May 12, 2009. 


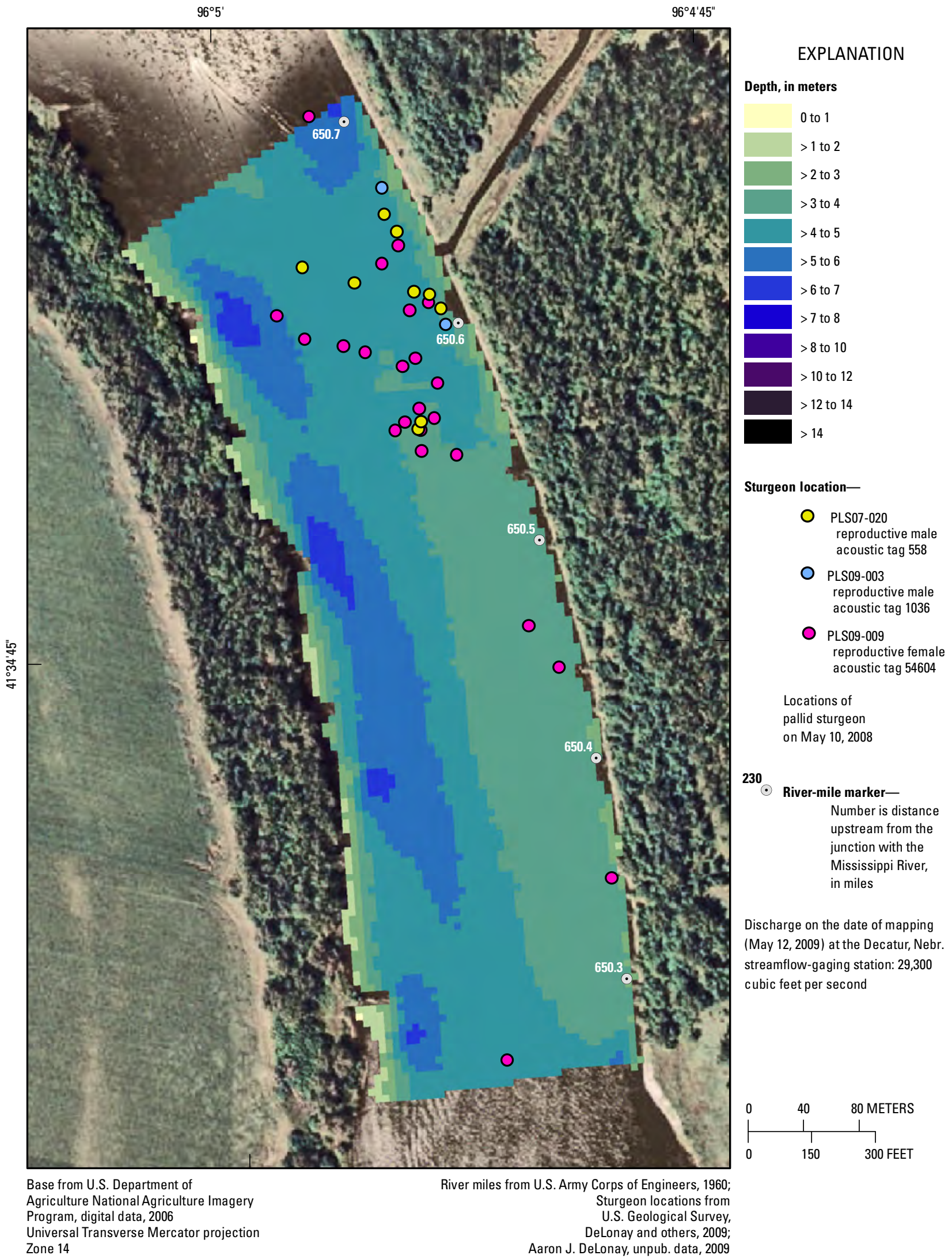

Figure 33. Single-beam depth map of location of probable spawning site of female pallid sturgeon PLS09-009, acoustic tag 54604, along with reproductive males PLS07-020, acoustic tag 558, and PLS09-003, acoustic tag 1036. Mapped May 12, 2009. 


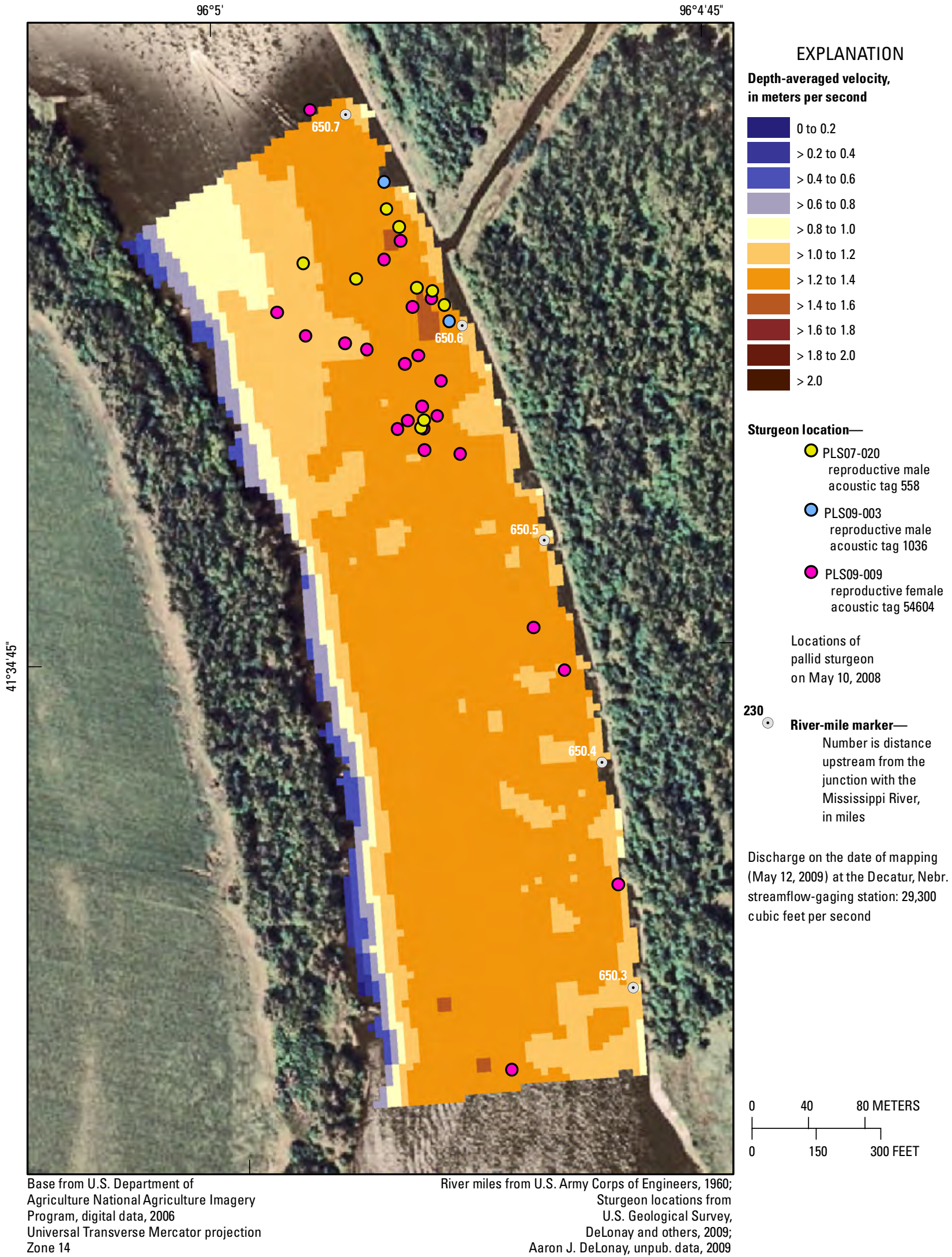

Figure 34. Acoustic Doppler current profiler velocity map of location of probable spawning site of female pallid sturgeon PLS09-009, acoustic tag 54604, along with reproductive males PLS07-020, acoustic tag 558, and PLS09-003, acoustic tag 1036. Mapped on May 12, 2009. 


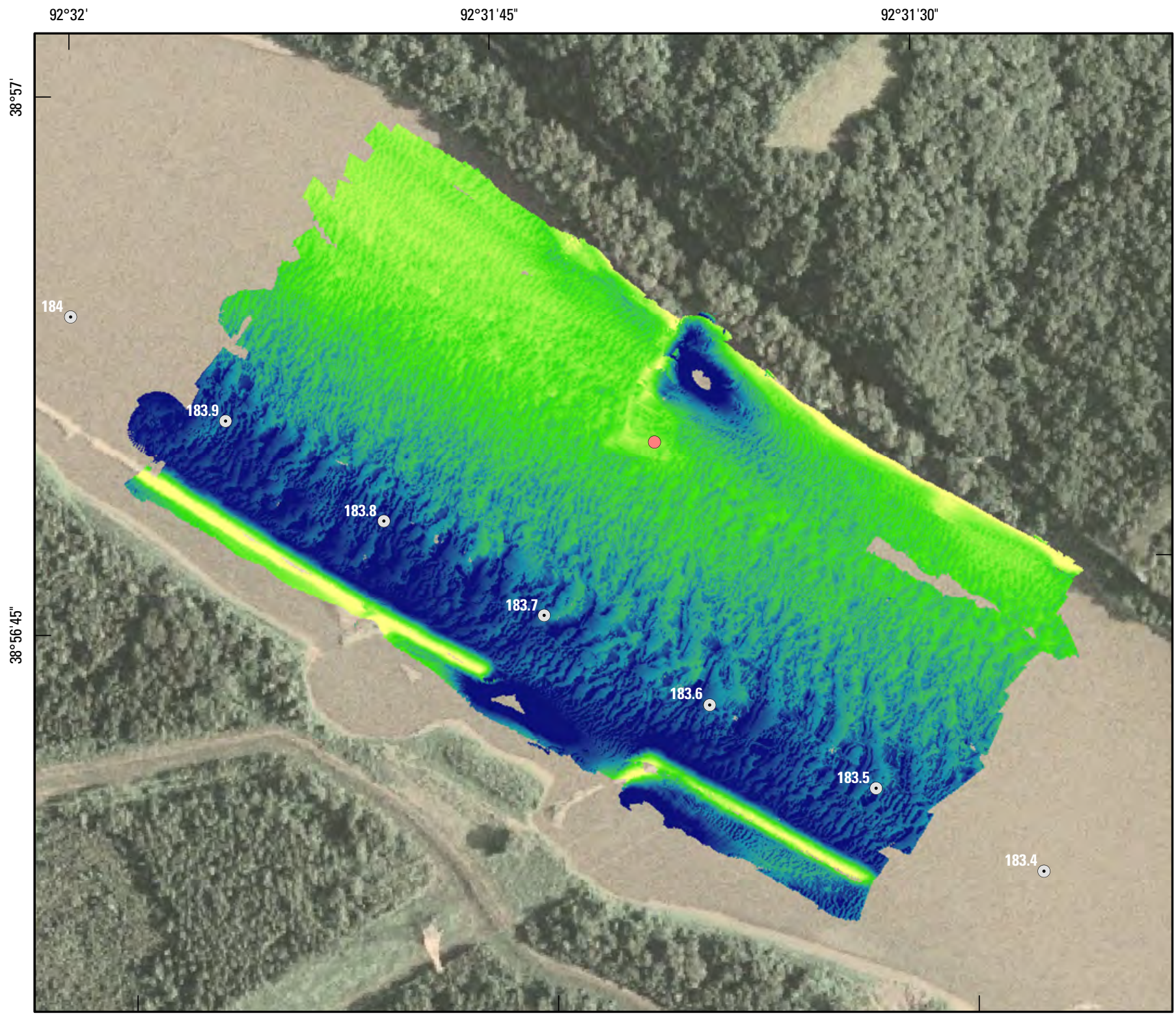

\begin{abstract}
Base from U.S. Department of
Agriculture National Agriculture Imagery

Program, digital data, 2006

Universal Transverse Mercator projection
\end{abstract}

Zone 15

River miles from U.S. Army Corps of Engineers, 1960; Sturgeon locations from DeLonay and others, 2009 .

EXPLANATION

\section{Depth, in meters}

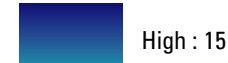

High : 15

Sturgeon location-

Location of

pallid sturgeon

PLS09-007

(acoustic tag 54500)

on April 20, 2009

230 .

$$
\begin{aligned}
& \text { River-mile marker- } \\
& \text { Number is distance } \\
& \text { upstream from the } \\
& \text { junction with the } \\
& \text { Mississippi River, } \\
& \text { in miles }
\end{aligned}
$$

Discharge on the date of mapping

(May 20, 2009) at the Boonville, Mo.

streamflow-gaging station: 168,000

cubic feet per second

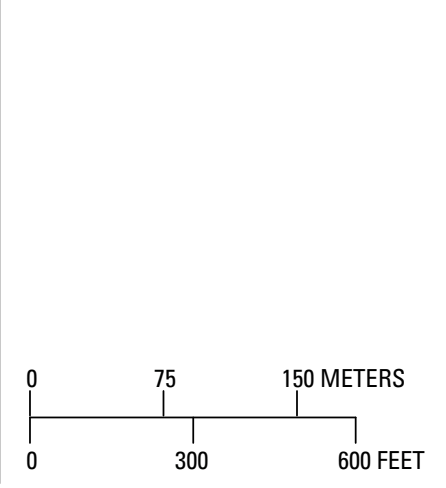

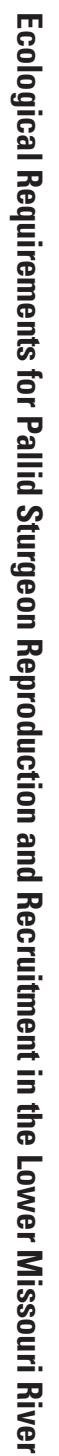

Figure 35. Multibeam bathymetric map of location of migrating female pallid sturgeon PLS09-007, acoustic tag 54500. Mapped April 21, 2009. Remapped May 20, 2009. 


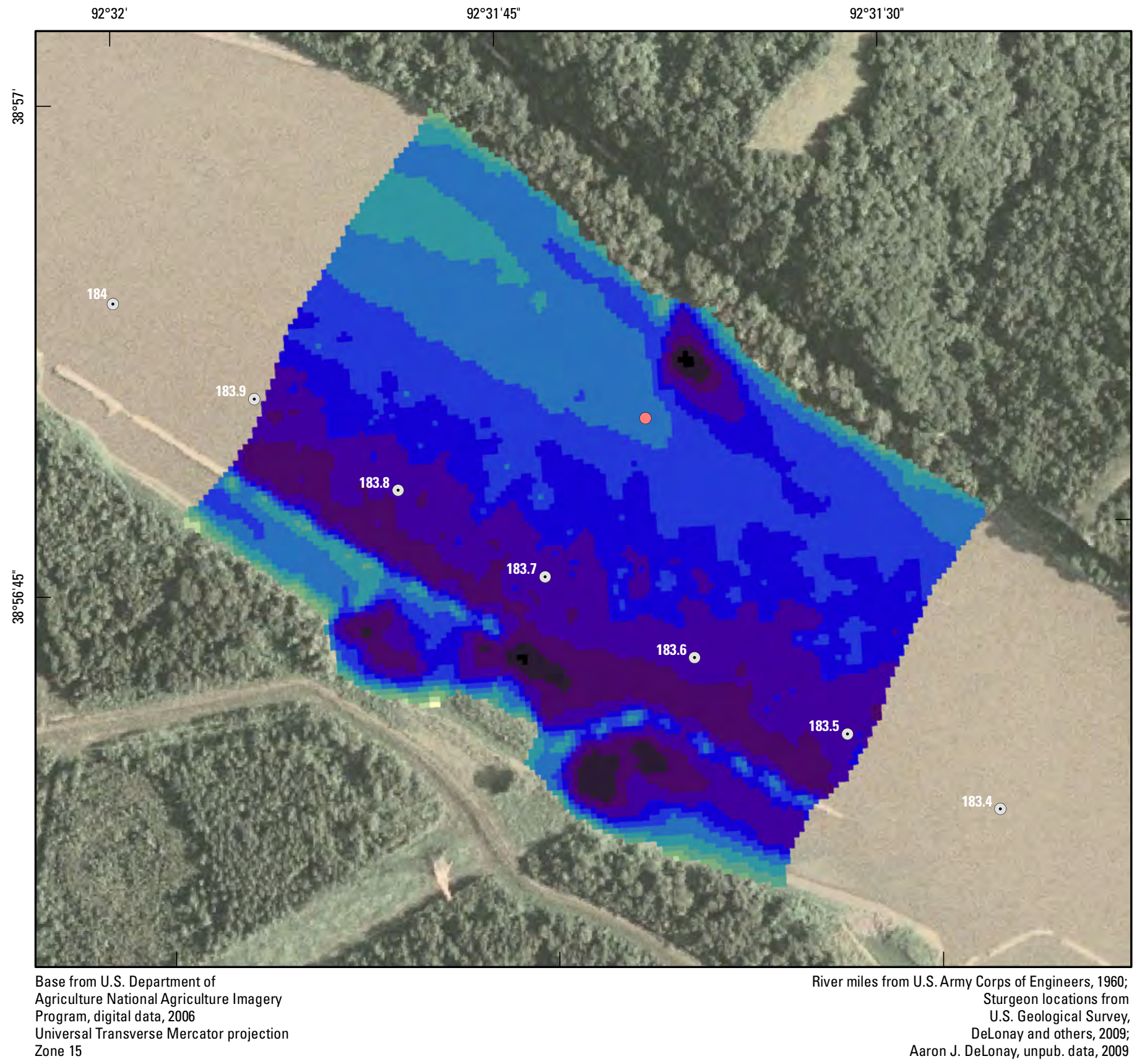

EXPLANATION

Depth, in meters

0 to 1

$>1$ to 2

$>2$ to 3

$>3$ to 4

$>4$ to 5

$>5$ to 6

$>6$ to 7

$>7$ to 8

$>8$ to 10

$>10$ to 12

$>12$ to 14

$>1$

Sturgeon locationLocation of
pallid sturgeon

PLS09-007

(acoustic tag 54500)

on April 20, 2009

River-mile marker-

Number is distance

upstream from the

junction with the

Mississippi River,

in miles

Discharge on the date of mapping

(May 20, 2009) at the Boonville, Mo.

streamflow-gaging station:

168,000 cubic feet per second

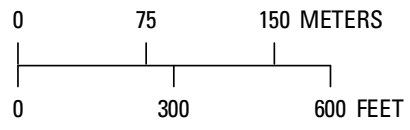

Ziversal Transverse Mercator projection

Aaron J. DeLonay, unpub. data, 2009

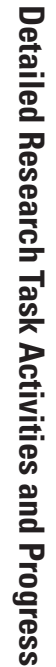

Figure 36. Single-beam depth map of location of migrating female pallid sturgeon PLS09-007, acoustic tag 54500. Mapped April 21, 2009. Remapped May 20, 2009. 


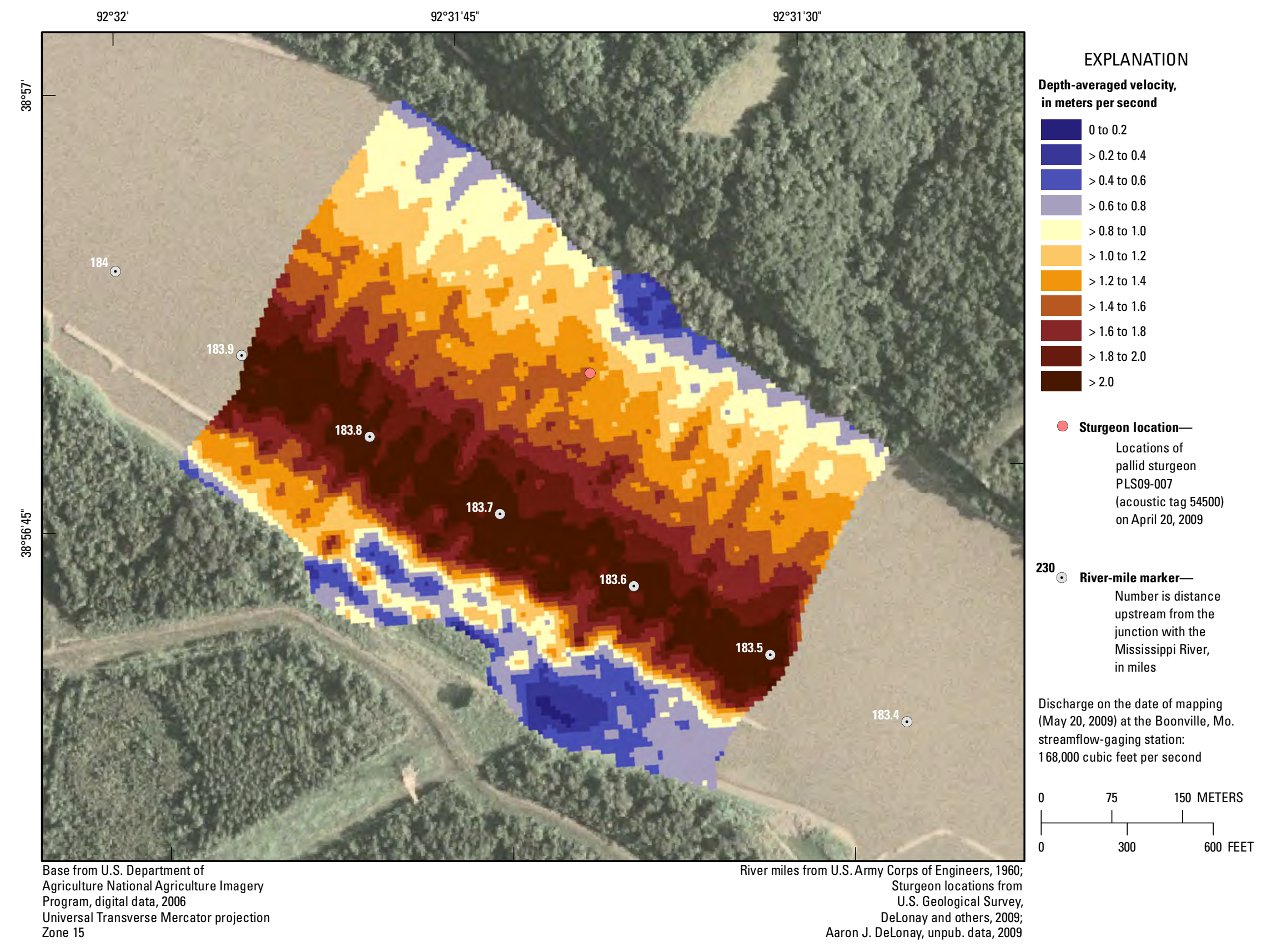

Figure 37. Acoustic Doppler current profiler velocity map of location of migrating female pallid sturgeon PLS09-007, acoustic tag 54500. Mapped April 21, 2009. Remapped May 20, 2009. 


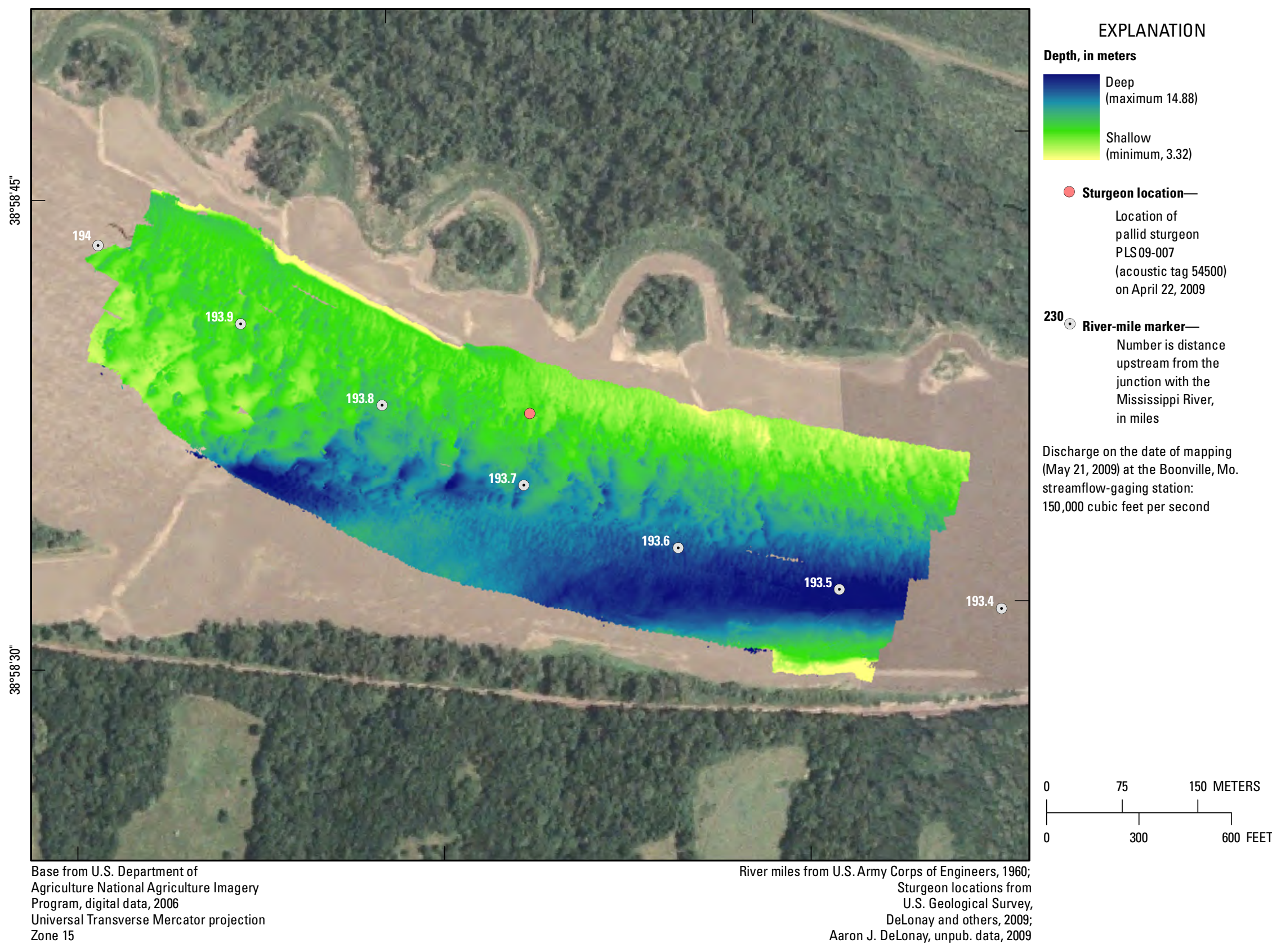




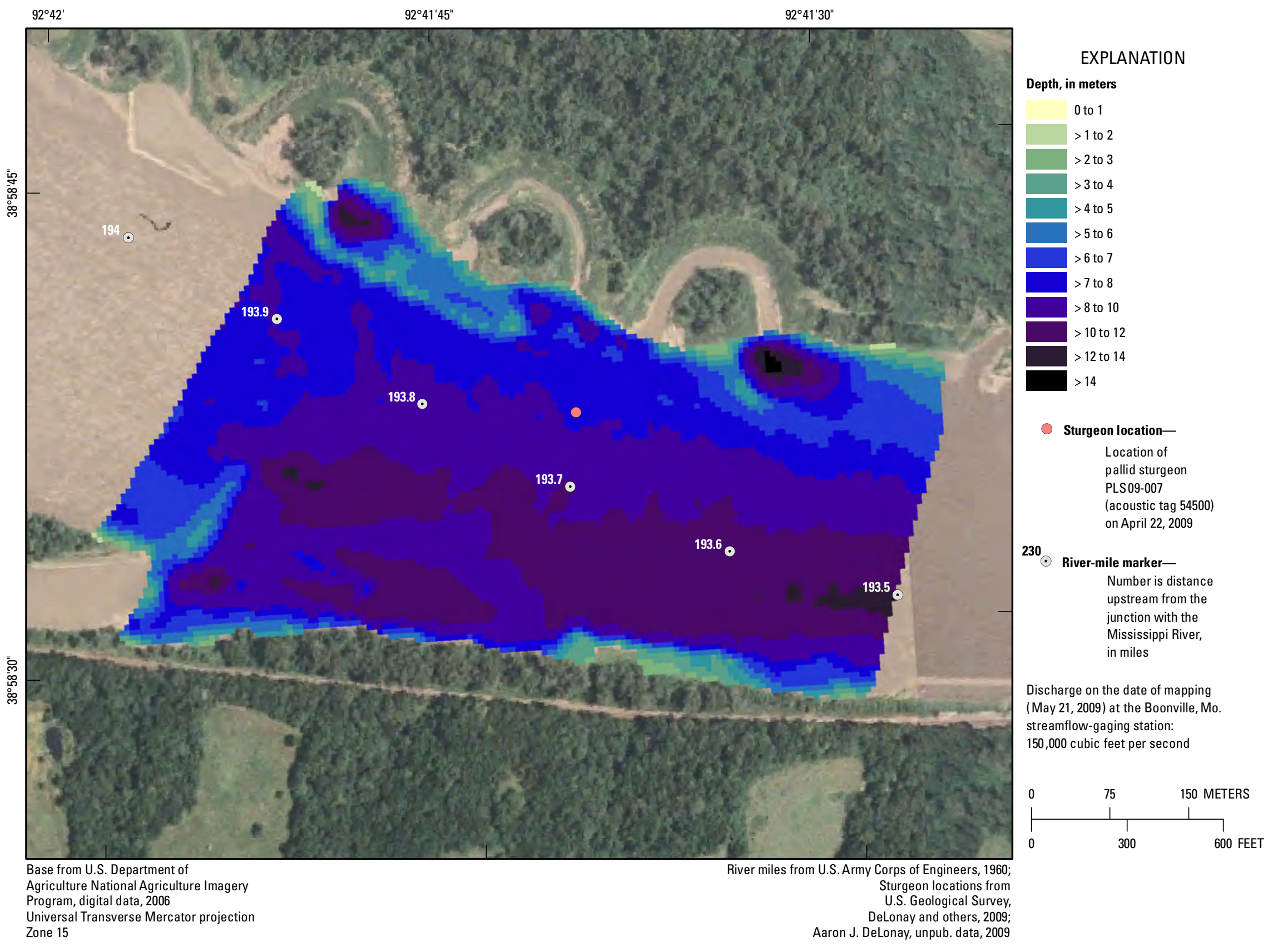

Figure 39. Single-beam depth map of location of migrating female pallid sturgeon PLS09-007, acoustic tag 54500. Mapped April 26, 2009. Remapped May 21, 2009. 


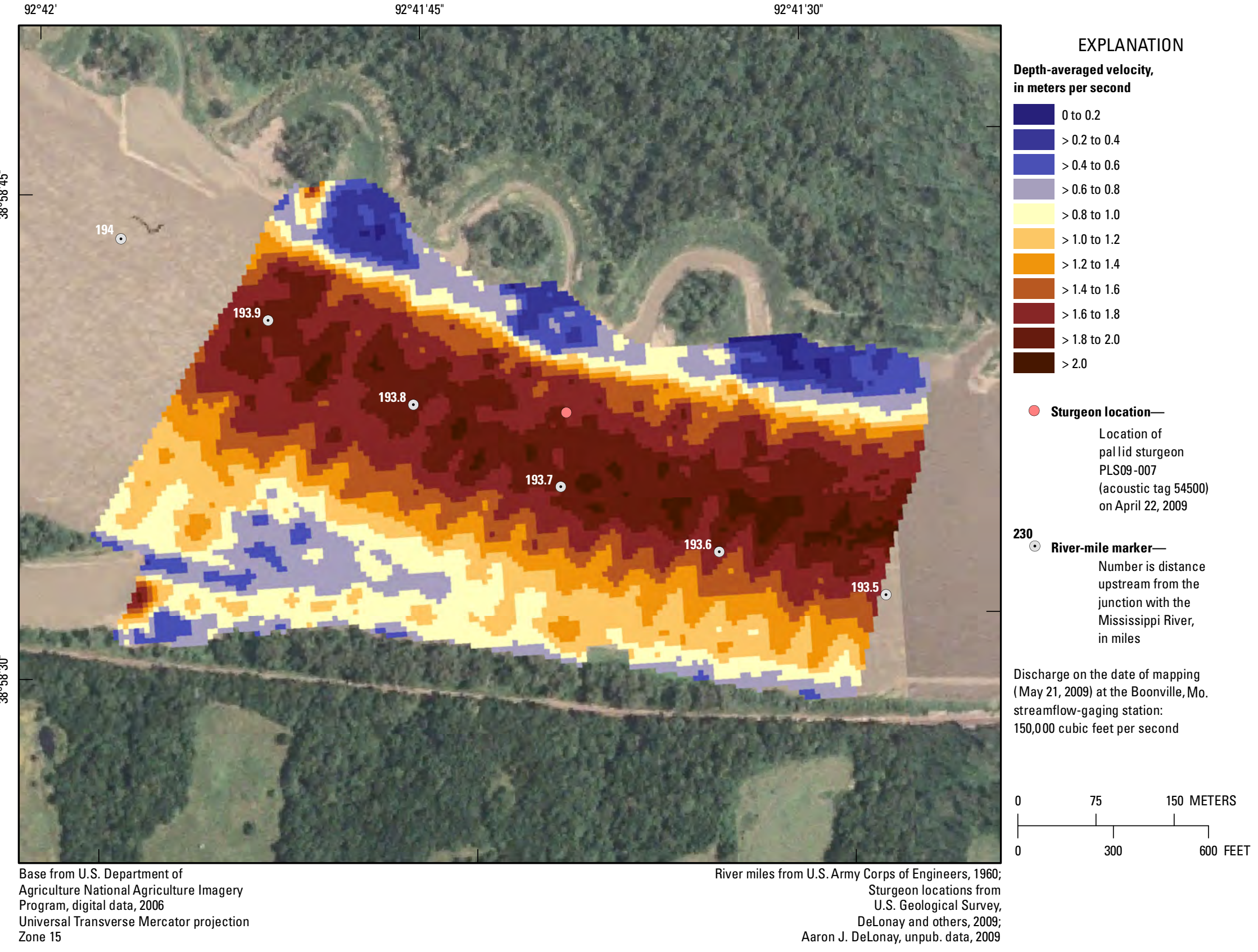

Figure 40. Acoustic Doppler current profiler velocity map of location of migrating female pallid sturgeon PLS09-007, acoustic tag 54500. Mapped April 26, 2009. Remapped May 21, 2009. 


\section{Discussion}

Similar to previous, extensive mapping of sturgeon migration locations, the 2009 maps document that migrating sturgeon are using relatively slow, shallow water on the inside of bends (Reuter and others, 2008; DeLonay and others, 2009; Reuter and others, 2009). This supports the idea that sturgeon may be selecting low-energy areas on insides of bends in their upstream migrations before crossing over to outside bends to search for specific spawning sites as spawning becomes imminent. The migration maps did not capture a sturgeon migrating upstream through a cross-over, but it is hypothesized that hydraulic conditions in cross-overs may present substantive obstacles to migration because of the lack of low-velocity pathways. Detailed mapping of locations through cross-overs may indicate strategies fish use to minimize stress in high-velocity areas.

The downstream spawning site at river mile 206.4 conforms to spawning sites documented at three sites in 2008 (figs. 26-28). All three sites were in deep (greater than $3 \mathrm{~m}$ ), fast (greater than $1 \mathrm{~m} / \mathrm{s}$ ), turbulent flow on the outsides of revetted bends. In contrast, at the two probable sites in the upstream section (river mile 659.7 and 650.6), male and female fish were spread over a broader area. In the downstream reaches in 2008 and 2009, the reproductive females stayed mostly in the deepest, fastest water in the thalweg. In 2009, DIDSON imagery confirmed that multiple fish were congregating in the same location as the gravid female pallid sturgeon. In the upstream reaches, the thalweg is not as well defined. The fish positions tend to coincide with the highest velocities but not the greatest depths. The two areas of fish concentration in the upstream reaches can be characterized as shoaling areas over mid-channel bars. Formation and movement of similar bars were observed during 2 years of channel-morphology monitoring just upstream at river mile 670 (Elliott and others, 2009); possibly, divergent flow over mid-channel bars is another preferred spawning habitat type for Missouri River sturgeon.

Remapping of two reaches at higher discharges confirmed substantial increases in the size and changes in the shapes of bedforms during small floods of less than bankfull stage (figs. 20-25, 24-40). These observations indicate that habitats experienced by benthic fishes like the pallid sturgeon are highly variable in time and space; the size and arrangement of dune-size bedforms, and the energy refugia associated with them, may exert an important control on the ability of sturgeon to forage effectively and migrate upstream efficiently.

\section{Summary and Conclusions}

Habitat mapping during 2009 confirmed some aspects of previously developed understanding of migration and spawning habitat: that migration tends to take place along inside bends and spawning is most likely occurring in deep (greater than $3 \mathrm{~m}$ ), fast (greater than $1 \mathrm{~m} / \mathrm{s}$ ) water on outside, revetted bends. Mapping of upstream probable spawning patches, however, indicated that fish aggregations may also occur at diverging flow over mid-channel bars.

Progress in understanding potential habitat limitations on pallid sturgeon reproduction will improve with additional replicates of the mapping efforts pursued in 2008 and 2009. Now that spawning habitats have been identified with some confidence at the scale of 10's of meters, a second set of questions can be addressed about quality of those habitats. Particular questions that have yet to be addressed relate to the fate of eggs once they are released: Are they transported downstream? Do they get lodged in the interstices of rocks and gravel, or adhere to the surface? Do they get covered with sediment? These factors will have a bearing on successful fertilization, incubation, and hatch. If sturgeon are spawning in two different types of habitats, how do these factors and probability of successful hatch vary among habitat types?

Although spawning patches have been identified on the Lower Missouri River, it is not known if these sites are optimal for spawning, or simply the best available. To put Lower Missouri River spawning sites into perspective, it would be very useful to map spawning habitat in other parts of the river system where spawning is suspected or known; sites like the Lower Yellowstone River or the Mississippi River at Chain of Rocks may provide more natural reference conditions for comparison.

The hypothesis that migration pathways may be limiting to pallid sturgeon remains to be explored more completely. Additional replicates of existing maps and coordinated mapping with high-frequency movements of sturgeon through a complete bend-crossover-bend sequence would provide an improved understanding of migration strategies and whether channel morphology could be reengineered to optimize passage.

Recent publications on larval drift rates of pallid sturgeon indicate that adequate drift distance may be a limiting factor if the fish drift downstream into lake environments as on the upper Missouri River (Braaten and others, 2008). On the Lower Missouri River, a related question is where channel reengineering should be pursued to maximize retention and habitat for larval growth? In previous habitat studies under CSRP, hundreds of acoustic Doppler current profiler transects have been collected that provide fundamental information on the retention potential for different parts of the river. These data could be used to parameterize advection/dispersion models of drifting particles to evaluate drift distances and the probability of retention.

\section{Task 4. Provide Database Integration, GIS Support, and Report Coordination}

\section{Background}

The research activities of CSRP generate large volumes of data about the physiology, ecology, and habitat 
requirements of pallid and shovelnose sturgeons. These data are useful in addressing management needs if properly organized, effectively displayed, carefully interpreted, and expeditiously published. Information management is critical to effective use of science by managers and the public, and it is, therefore, essential to develop a robust platform for data collection, integration, maintenance, analysis, visualization, and distribution.

\section{Scope and Objectives}

The general objectives of ongoing task 4 are to (1) develop and maintain a standardized mobile mapping and electronic data-collection framework to support simultaneous data collection from several field crews, (2) compile and maintain data collected for CSRP, and (3) develop and maintain near real-time data reporting.

\section{Methods}

CSRP involves simultaneous data collection from multiple field crews over 800 miles of river requiring the need for a robust and scalable relational database as well as standardized data-collection parameters. The Sturgeon Information Management System (SIMS) framework was completed within USGS for data collection and maintenance using a range of software and hardware products to manage the volume and diversity of data collected by CSRP (fig. 41).
The SIMS framework relies on ArcPad® (ESRI, Redlands, Calif.) for mobile mapping and electronic data collection of telemetry locations and search efforts of telemetry crews. ArcGIS ${ }^{\circledR}$ has been utilized to manage the telemetry data collected using $\operatorname{ArcPad}{ }^{\circledR}$ (location events for all individual sturgeon and search effort data). SQL Server 2000®

(Microsoft Inc., Seattle, Wash.) has been used to manage tabular data (information about each fish, for example, sex, length, and weight). A custom SIMS user interface was developed using Microsoft Access ${ }^{\circledR} 2007$ (Microsoft Inc., Seattle, Wash.) to allow quick access to near real-time reports that incorporate information from spatial data (telemetry location data) and tabular data.

The customized SIMS ArcPad $\AA$ application was developed and deployed on ruggedized laptop computers for mobile field mapping and electronic data collection of all location events for implanted sturgeon. This $\mathrm{ArcPad} \AA$ application allows field personnel to view, capture, edit, and display geospatial data easily and efficiently. A series of four custom edit forms walk a user through a typical telemetry observation session. The edit forms prompt the observer to record information identifying a particular fish (based on acoustic tag number and frequency) and enable the observer to describe the water quality, hydrologic conditions, habitat, and substrate. Field data are input from drop-down menus or by using the keyboard for text fields. Additionally, the application automatically records date, time, and spatial coordinates from the GPS unit. The SIMS ArcPad® application also is used to document the search efforts of all

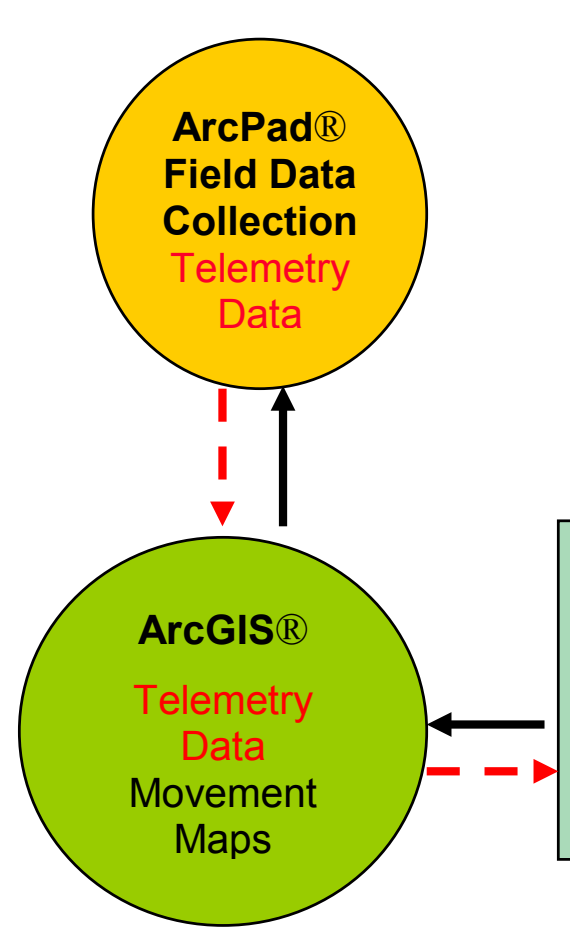

\section{Relational} Database (SQL Server ${ }^{\circledR}$ ) Tabular Data Storage

Create Reports Summarize Data

Figure 41. Diagram of the database platform illustrating data outflow (red lines) and data inflow (black lines). 
telemetry crews. Data collected for each search effort include the date, time, spatial coordinates, crew members, search type (drift, intensive monitor, or search for a specific fish), types of transmitter receivers used, and the radio and acoustic frequencies scanned during the search effort.

All data for sturgeon relocations and search efforts are uploaded on a daily basis to a secure server located at CERC. The data from each crew are then archived. The new sturgeon location events and search efforts and all associated data are incorporated into the larger spatial database using a custom ArcMap ${ }^{\circledR}$ application created to aid in managing the daily sturgeon relocation and search effort data.

Sturgeon telemetry location data are linked (by linked server technology in SQL Server 2000®) to the other essential data in the SIMS database framework. Linkages have been established between spatial data and data tables in the database using mutually exclusive identifiers, allowing summary reports to be generated using information from several data sources. These linkages allow the spatial data to be maintained in its native format, while still being accessed by the database, thereby, making it possible to maintain data in a near real-time environment.

The database and spatial data linkages also are used to create map products. Maps are created for movements of each individual fish, showing the release location, all relocation events, the last known relocation and lines connecting the relocations to show the upstream and downstream movements. These maps provide information on the movements of each individual fish through space and time. Because of the linkages between the database and the spatial data collected by the field crews, the data driving these maps are created and maintained in the database in near real time.

The SIMS user interface allows users to update data easily, view data, and access readily available summary reports. The data and reports accessed through the SIMS user interface are near real time. The complex linkages between the database and spatial data are essential to the creation of useful textual reports on fish movements and search efforts.

Data quality and integrity are a constant priority for the SIMS near real-time database, and validation efforts are constantly being reviewed and improved. All forms used for electronic data entry and to update data have built-in data validation controls that warn users when an entered value is outside the expected range. Numerous internal reports also have been developed to manage quality-assurance and qualitycontrol measures.

\section{Results}

Between 2004 and 2009 more than 10,550 pallid and shovelnose sturgeon locations have been recorded and archived using SIMS. During 2009, USGS and NGPC field crews uploaded data from 407 search efforts, including information on 1,118 pallid sturgeon telemetry locations. Additionally, SIMS has been used to record 13 initial implantation locations and 15 recapture events of pallid sturgeon in 2009. SIMS was leveraged to create over 500 dynamic movement maps, charts, and graphs for individual fish in preparation of a USGS Open-File Report documenting capture, tagging and tracking methods, and data-collection efforts.

In total, SIMS houses 25 tables essential to reporting the results of task 1 of the CSRP. In 2009, nine additional data tables were created to maintain data for genetic samples, physiology samples, larval fish samples, hatchery origin information, and transmitter tag inventory.

The SIMS user interface was upgraded to include 12 new reports addressing frequent data requests. Additionally, a new charting functionality was developed to show the movements of any number of individual sturgeon selected by a user. The individual sturgeon reports were upgraded to contain hyperlinks to all capture/recapture photographs for each sturgeon, allowing quick and easy access.

\section{Discussion}

Traditionally, collection and compilation of field telemetry data have been paper-based processes requiring multiple points of data entry, first recording the data in the field, and later transferring the data from paper records into a database. Recently, mobile mapping applications and digital data-collection platforms allow users to create and edit data in the field. This process provides access to realtime information in the field and the ability to communicate field observations quickly back to the office using secure file transfer protocols. These digital data-collection technologies coupled with a robust database allow data and reports to be updated on a near real-time basis, providing the most current information possible. SIMS (1) reduces or eliminates the need for paper field sheets; (2) eliminates the need to enter information from field sheets into database, thereby, reducing errors and time lag; (3) is customizable to streamline specific tasks; and (4) performs real-time data validation and reporting.

SIMS is also key to analyzing and understanding sturgeon movement patterns within the Missouri River and allowing researchers to visualize sturgeon migration through space and time. The SIMS platform puts powerful near real-time information in the hands of researchers and managers quickly and easily by way of the user interface. The on-demand reports formatted in the Microsoft Access user interface output up-to-date information frequently requested by researchers and managers. These reports detail a wide variety of information, from project level summary statistics to individual fish summaries. For example, one report details the number of pallid sturgeon with active transmitters and highlights those that are at risk of transmitter expiration, and, therefore, need to be targeted for immediate recapture. Another report displays the history of the individual fish during the multiple years of the CSRP, including gender, origin (wild or hatchery), reproductive history, and migration pathway (fig. 42). SIMS puts up-to-date information in the 

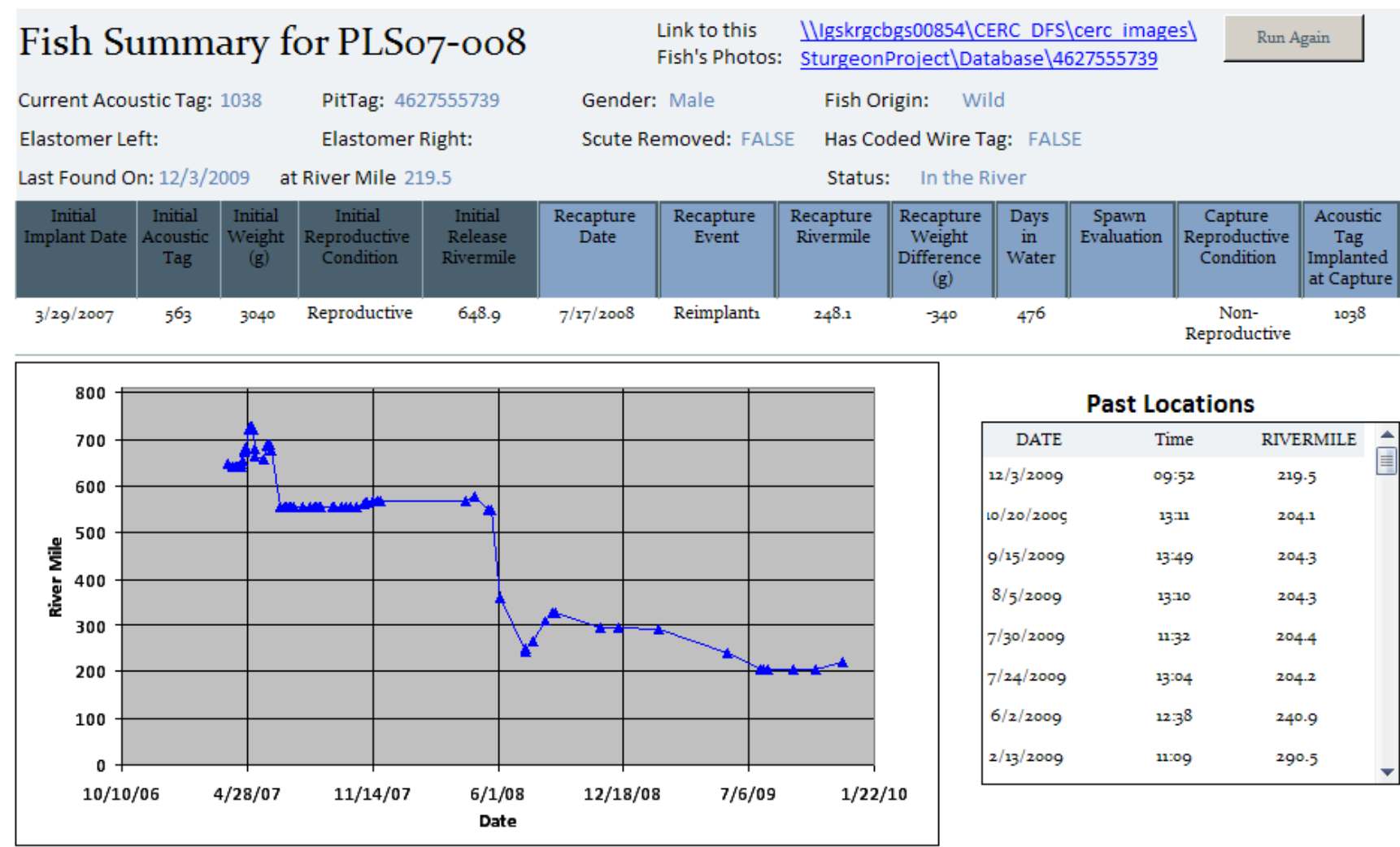

Past Locations

\begin{tabular}{|rcc|}
\hline DATE & Time & RIVERMILE \\
$12 / 3 / 2009$ & $09: 52$ & $219 \cdot 5$ \\
$10 / 20 / 2009$ & $13: 11$ & 204.1 \\
$9 / 15 / 2009$ & $13: 49$ & $204 \cdot 3$ \\
$8 / 5 / 2009$ & $13 \cdot 10$ & 204.3 \\
$7 / 30 / 2009$ & $11: 32$ & 204.4 \\
$7 / 24 / 2009$ & $13: 04$ & 204.2 \\
$6 / 2 / 2009$ & $12: 38$ & 240.9 \\
$2 / 13 / 2009$ & $11: 09$ & 290.5
\end{tabular}

Surgery Table Notes

Pallid Capture History

\begin{tabular}{|c|c|c|c|c|c|c|}
\hline & \\
\hline Capture & Notes & Date_ & Capture & Released & CapAgency & Rivermile \\
\hline \multirow[t]{2}{*}{ Initial Implantation } & spawning male & $3 / 29 / 2007$ & Sampling & Released & USGS & 648.9 \\
\hline & & $7 / 17 / 2008$ & Targeted & Released & USGS & 248.1 \\
\hline Reimplant1 & $\begin{array}{l}\text { Stage III, possibly repro next spring; incision healed very } \\
\text { well; redness around radio wire; overall fish health is good }\end{array}$ & $9 / 5 / 2008$ & & & & 328.9 \\
\hline
\end{tabular}

Figure 42. An example of the Individual Fish Summary report generated via the user interface.

hands of researchers to prioritize and schedule field crew efforts to track, map, and recapture sturgeon.

SIMS allows for quick compilation and dissemination of information, internally and externally, as information is frequently requested by other programs and agencies to aid in decision making. Data often are requested by the Missouri Department of Transportation, Environmental Design Section prior to any bridge construction, demolition, or alteration. During 2009, pallid sturgeon telemetry location data also were provided to the USACE, Emergent Sandbar Habitat Program. Information frequently is shared with USFWS and several State agencies regarding the history for many fish captured during the broodstock collection effort. Data also are exchanged with other agencies/programs in order to form a complete picture for individual fish. SIMS ensures that information sharing between groups is a seamless transaction. Collaboration with Middle Basin Pallid Sturgeon Work Group ensures data exchange/retrieval on telemetered pallid sturgeon giving precise locations for telemetered fish removed or returned to the river before and after use for propagation efforts. SIMS also allows for coordination with the Population Assessment Project database manager to obtain and integrate initial capture data for any telemetered pallid sturgeon obtained from propagation efforts.

\section{Conclusions}

Work in 2010 is expected to include expanding digital data collection to field sampling aimed at initial capture and targeted recapture of pallid sturgeon. The additional ArcPad $\AA$ application will be customized to streamline data collection for sampling and recapture of pallid sturgeon, including gear deployment, retrieval information, and physical habitat data. This application will eliminate data entry from field data sheets and support near real-time reporting. 
The relational database will be maintained using Microsoft SQL Server 2000® to manage and integrate tabular data for individual sturgeon. Anticipated future efforts will leverage the linkages within the database platform to create a temporal and spatial animation of telemetry location data, depth, and temperature data. This animation will serve to illustrate the movements of spawning pallid sturgeon in response to environmental cues.

\section{Acknowledgements}

This report benefitted from technical reviews by David Herzog, Craig Paukert, Carl Korschgen, Craig Fleming, and Roy McAllister. Funding for this research was provided by the U.S. Army Corps of Engineers, Missouri River Recovery-Integrated Science Program and the USGS.

\section{References Cited}

Bajer, P.G., and Wildhaber, M.L., 2007, Population viability analysis of Lower Missouri River shovelnose sturgeon with initial application to the pallid sturgeon: Journal of Applied Ichthyology, v. 23, p. 457-464.

Bergman, H.L., Boelter, A.M., Parady, K., Fleming, C., Keevin, T., Latka, D.C., Korschgen, C., Galat, D.L., Hill, T., Jordan, G., Krentz, S., Nelson-Stastny, W., Olson, M., Mestl, G.E., Rouse, K., and Berkley, J., 2008, Research needs and management strategies for pallid sturgeon recovery: William D. Ruckelshaus Institute of Environment and Natural Resources, University of Wyoming, Laramie Proceedings of a Workshop held July 31-August 2, 2007, $37 \mathrm{p}$.

Braaten, P.J., Fuller, D.B., Holte, L.D., Viste, W., Brandt, T.F., and Legare, R.G., 2008, Drift dynamics of larval pallid sturgeon and shovelnose sturgeon in a natural side channel of the Missouri River, Montana: North American Journal of Fisheries Management, v. 28, p. 808-826.

Bramblett, R.G., and R.G., White, 2001, Habitat use and movements of pallid and shovelnose sturgeon in the Yellowstone and Missouri Rivers in Montana and North Dakota: Transactions of the American Fisheries Society, v. 130 , p. 1006-1025.
Conte, F.S., Doroshov, S.I., Lutes, P.B., and Strange, E.M., 1988, Hatchery manual for the white sturgeon with applications to the North American Acipenseridae: Davis, Calif., University of California, 104 p.

DeLonay, A.J., Jacobson, R.B., Papoulias, D.M., Simpkins, D.G., Wildhaber, M.L., Reuter, J.M., Bonnot, T.W., Chojnacki, K.A., Korschgen, C.E., Mestl, G.E., and Mac, M.J., 2009, Ecological requirements for pallid sturgeon reproduction and recruitment in the Lower Missouri River-A research synthesis 2005-08: U.S. Geological Survey Scientific Investigations Report 2009-5201, 59 p., accessed on January 21, 2010, at http://pubs.usgs.gov/sir/2009/5201/

DeLonay, A.J., Little, E.E., Rabeni, C.F., 2000, Approaches for monitoring pallid sturgeon movement and assessing habitat use in the Lower Missouri River, in, Eiler, J.H., Alcorn, D.J., and Neuman, M.R., eds., Biotelemetry 15: Proceedings of the 15th International Symposium on Biotelemetry, Juneau, Alaska: International Society on Biotelemetry, Wageningen, The Netherlands, p. 186-192.

DeLonay, A.J., Papoulias, D.M., Wildhaber, M.L., Annis, M.L., Bryan, J.L., Griffith, S.A., Holan, S.H., and Tillitt, D.E., 2007a, Use of behavioral and physiological indicators to evaluate Scaphirhynchus sturgeon spawning success: Journal of Applied Ichthyology, v. 23, no. 4, p. 428-435.

DeLonay, A.J., Papoulias, D.M., Wildhaber, M.L., Mestl, G.E., Everitt, D.W., and Chojnacki, K.A., 2007b, Movement, habitat use, and reproductive behavior of shovelnose sturgeon and pallid sturgeon in the Lower Missouri River, in Korschgen, C., ed., Factors affecting the reproduction, recruitment, habitat, and population dynamics of Pallid Sturgeon and Shovelnose Sturgeon in the Missouri River: U.S. Geological Survey Open-File Report 2007-1262, p. 23-102.

Elliott, C.M., Reuter, J.M., and Jacobson, R.B., 2009, Channel morphodynamics in four reaches of the Lower Missouri River, 2006-07: U.S. Geological Survey Scientific Investigations Report 2009-5074, 258 p., accessed on January 21, 2010, at http://pubs.usgs.gov/sir/2009/5074/

Galat, D.L., and Lipkin, R., 2000, Restoring ecological integrity of great rivers: Historical hydrographs aid in defining reference conditions for the Missouri River: Hydrobiologia, v. 422, p. 29-48. 
Garvey, J.E., Heist, E.J., Brooks, R.C., Herzog, D.P., Hrabik, R.A., Killgore, K.J., Hoover, J.J., and Murphy, C.E., 2009, Current status of the pallid sturgon in the Middle Mississippi River: habitat, movement, and demographics: U.S. Army Corps of Engineers, 353 p., accessed on January 21, 2010, at http://fishdata.siu.edu/pallid

Holan, S.H., Davis, G., Wildhaber, M.L., DeLonay, A.J., and Papoulias, D.M., 2009, Markov switching models with application to predicting spawning success of shovelnose sturgeon: Journal of the Royal Statistical Society: Series C (Applied Statistics), v. 58, p. 1-18.

Hurley, K.L., R.J., Sheehan, R.C., Heidinger, P.S., Wills, and B., Clevenstine, 2004, Habitat use by middle Mississippi River pallid sturgeon: Transactions of the American Fisheries Society, v. 133, p. 1033-1041.

Hurley S.T., Hubert W.A., and Nickum J.G., 1987, Habitats, movements of shovelnose sturgeons in the upper Mississippi river: Transactions of the American Fisheries Society, v. 116, p. 655-663.

Jacobson, R.B., and Galat, D.L., 2008, Design of a naturalized flow regime on the Lower Missouri River: Ecohydrology, v. 1 , no. 2, p. 81-104.

Jacobson, R.B., Johnson, H.E., III, and Dietsch, B.J., 2009, Hydrodynamic simulations of physical aquatic habitat availability for pallid sturgeon in the Lower Missouri River, at Yankton, South Dakota, Kenslers Bend, Nebraska, Little Sioux, Iowa, and Miami, Missouri, 2006-07: U.S. Geological Survey Scientific Investigations Report 20095058, 67 p., accessed on January 21, 2010, at http://pubs.usgs.gov/sir/2009/5058/

Latka D.C., Ramsey J.S., and Morris J.E., 1995, Selection of tributary confluence habitat by shovelnose sturgeon in the channelized Missouri river, in, Gershanovich, A.D., Smith T.I.J., eds., Proceedings, Second International Symposium on Sturgeons, 1993: VNIRO Publications, Moscow, p. $250-258$.

Mathews, R., and Richter, B.D., 2007, Application of the indicators of hydrologic alteration software in environmental flow setting: Journal of the American Water Resources Association, v. 43, no. 6, p. 1400-1413.
Quist, M.C., Boelter, A.M., Lovato, J.M., Korfanta, N.M., Bergman, H.L., Latka, D.C., Korschgen, C., Galat, D.L., Krentz, S., Oetker, M., Olson, M., Scott, C.M., and Berkley, J., 2004, Research and assessment needs for pallid sturgeon recovery in the Missouri River--Final report to the U.S. Geological Survey, U.S. Army Corps of Engineers, U.S. Fish and Wildlife Service, and U.S. Environmental Protection Agency: Laramie, Wyo., William D. Ruckelshaus Institute of Environment and Natural Resources, University of Wyoming, $82 \mathrm{p}$.

Quist, M.C., Tillma, J.S., Burlingame, M.N., and Guy, C.S., 1999, Overwinter habitat use of shovelnose sturgeon in the Kansas River: Transactions of the American Fisheries Society, v. 128, p. 522-527.

RD Instruments, 2003, WinRiver users's guide: Poway, Calif., RD Instruments, Inc., 144 p.

Reuter, J.M., Jacobson, R.B., Elliott, C.M., and DeLonay, A.J., 2009, Assessment of Lower Missouri River physical aquatic habitat and its use by adult sturgeon (genus Scaphirhynchus) 2005-07: U.S. Geological Survey Scientific Investigations Report 2009-5121, 81 p., accessed on January 21, 2010, at http://pubs.er.usgs.gov/usgspubs/sir/sir20095121

Reuter, J.M., Jacobson, R.B., Elliott, C.M., Johnson, H.E., III, and DeLonay, A.J., 2008, Hydraulic and substrate maps of reaches used by sturgeon (genus Scaphirhynchus) in the Lower Missouri River, 2005-07: U.S. Geological Survey Data Series Report 386, 442 p., accessed on January 21, 2010, at http://pubs.usgs.gov/ds/386/

Simpkins, D.G., and LaBay, S.R., 2007, Site-specific assessment of spawning behavior and habitat use, in Korschgen, C., ed., Factors affecting the reproduction, recruitment, habitat, and population dynamics of Pallid Sturgeon and Shovelnose Sturgeon in the Missouri River: U.S. Geological Survey Open-File Report 2007-1262, p. 217-254.

Richter, B.D., and Thomas, G.A., 2007, Restoring environmental flows by modifying dam operations: Ecology and Society, [online] URL: http://www.ecologyandsociety. org/vol12/iss1/art12/, v. 12, no. 1, p. 1-26.

Sustainable Ecosystems Institute, 2008, Review of comprehensive sturgeon research program: Sustainable Ecosystems Institute, 49 p., accessed on January 21, 2010, at http://sei.org/sturgeon/MR_USGS-Program-FinalReport.pdf 
Snook, V.A., and Peters, E.J., 2002, Movements and habitat use by hatchery-reared pallid sturgeon in the Lower Platte River, Nebraska, in, Van Winkle, W., Anders, P.J., Secor, D.H., and Dixon, D.A., eds., Biology, Management, and Protection of North American Sturgeon: American Fisheries Society, Symposium 28, Bethesda, Maryland, p. 161-174.

U.S. Army Corps of Engineers, 2008, Missouri River Mainstem System - 2008-2009 Annual Operating Plan: Omaha, Nebraska, Northwestern Division, Missouri River Basin, Water Management Division, $85 \mathrm{p}$.

U.S. Fish and Wildlife Service, 2003, Amendment to the 2000 biological opinion on the operation of the Missouri River main stem reservoir system, operation and maintenance of the Missouri River bank stabilization and navigation project, and operation of the Kansas River reservoir system: U.S. Fish and Wildlife Service, 308 p., accessed on January 21, 2010, at http://www.nwd-mr.usace.army.mil/mmanual/ FinalBO2003.pdf

Wildhaber, M.L., DeLonay, A.J., Papoulias, D.M., Galat, D.L., Jacobson, R.B., Simpkins, D.G., Braaten, P.J., Korschgen, C.E., and Mac, M.J., 2007, A conceptual life-history model for pallid and shovelnose sturgeon: U.S. Geological Survey Circular 1315, 18 p., accessed on January 21, 2010, at http://pubs.usgs.gov/circ/2007/1315/ 



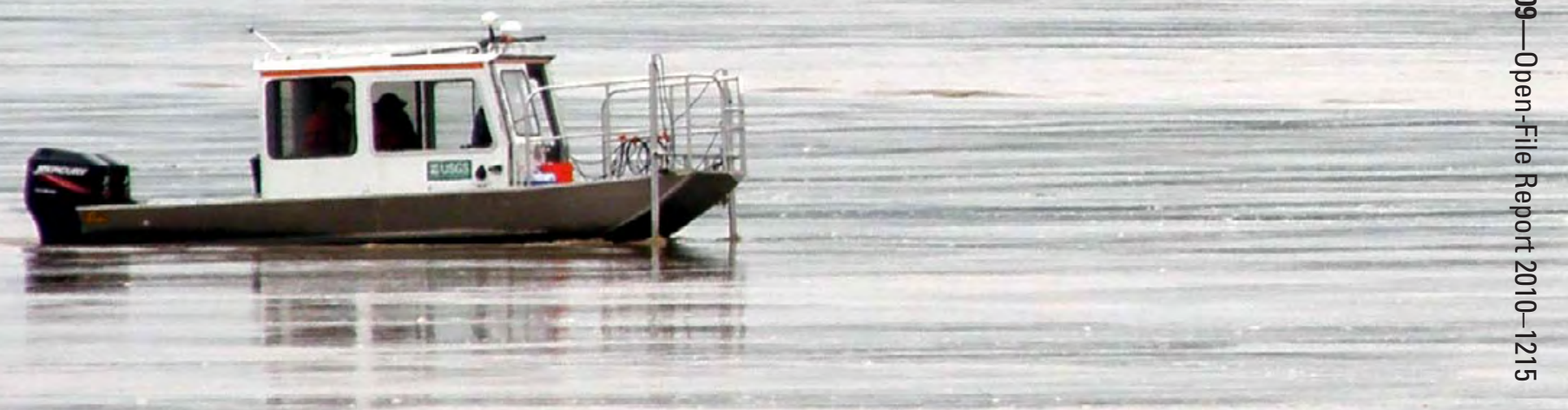

